\title{
EFEITO DO MANEJO DA VENTILAÇÃO NATURAL NO AMBIENTE DE SALAS DE MATERNIDADE PARA SUINOS
}

\section{ANGÉLICA SIGNOR MENDES}

Engenheira Agrícola

Orientadora: Prof ${ }^{\mathrm{a}}$. Dra ${ }^{\mathrm{a}}$. DANIELLA JORGE DE MOURA

Dissertação apresentada à Escola Superior de Agricultura "Luiz de Queiroz", Universidade de São Paulo, para obtenção do título de Mestre em Agronomia, Área de Concentração: Física do Ambiente Agrícola.

P I R A C I C A B A

Estado de São Paulo - Brasil

Junho - 2005 
Dados Internacionais de Catalogação na Publicação (CIP) DIVISÃO DE BIBLIOTECA E DOCUMENTAÇÃO - ESALQ/USP

Mendes, Angélica Signor

Efeito do manejo da ventilação natural no ambiente de salas de maternidade para suinos / Angélica Signor Mendes. - - Piracicaba, 2005.

89 p. : il.

Dissertação (mestrado) - - Escola Superior de Agricultura Luiz de Queiroz, 2005.

Bibliografia.

1. Aclimatação animal 2. Comportamento animal 3. Confinamento animal 4. Conforto térmico das construçōes 5 . Instalação para animal 6 . Suinocultura 7. Temperatura ambiental 8. Ventilação I. Título

CDD 636.408931

"Permitida a cópia total ou parcial deste documento, desde que citada a fonte - O autor" 


\section{AGRADECIMENTOS}

À orientadora, Professora $\mathrm{Dr}^{\mathrm{a}}$. Daniella Jorge de Moura, pela confiança, atenção, incentivo e ensinamentos, que tanto contribuíram para meu crescimento científico.

À amiga, Daniella Jorge de Moura, pela amizade, momentos de descontração, humanidade e por tudo o que fez e tem feito para amenizar as dificuldades que enfrento por estar tão longe dos meus.

À Professora $D^{a}$. Irenilza de Alencar Nääs, pela estimada confiança, atenção, sugestões e ensinamentos.

Ao Professor Dr. Quirijn de Jong Van Lier, Coordenador do Programa de PósGraduação, pela confiança, praticidade e facilidade com que sempre ajudou na solução dos problemas referentes ao meu trabalho.

Ao Professor Dr. Sergio Oliveira Moraes, pelas palavras de incentivo e entusiasmo sobre meu trabalho.

Ao Sr. Paulo César Micheloni e funcionários da Granja Querência, pela confiança, atenção e preciosas sugestões para a execução deste trabalho.

Ao Sr. Carlos Santa Cruz e funcionários da Empresa Technisul, pela confiança em meu trabalho, auxílio e incentivo. 
Aos colegas de laboratório da FEAGRI, por terem me acolhido com muito carinho e tanto auxílio me ofereceram: Eduardo (Pycachú), Douglas (Overman), Yamília (Entendio?), Sílvia (Maria), Marta (Martinha), Ana Caroline (Carol), Eduardo (David), Marcos Paulo, Victor e Mário Mollo.

Aos alunos de IC, Frederico Lochaidy e Willian Ferreira, pelo estimado auxílio na coleta dos dados e sugestões.

À Coordenação de Aperfeiçoamento de Pessoal de Nível Superior (CAPES), pela concessão de bolsa de estudos. 


\section{SUMÁRIO}

Página

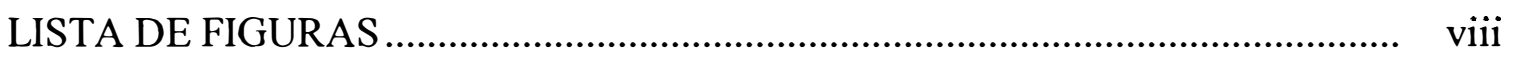

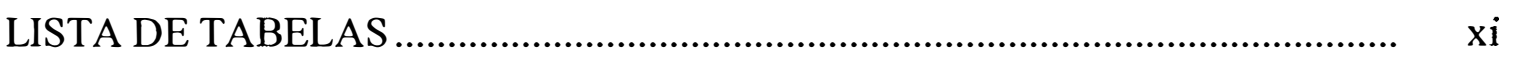

NOMENCLATURA …………….............................................................. xiv

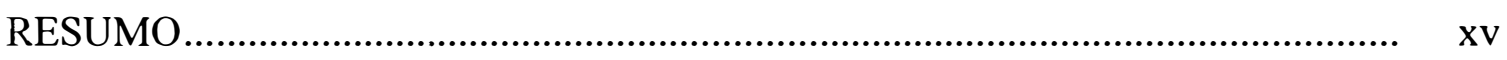

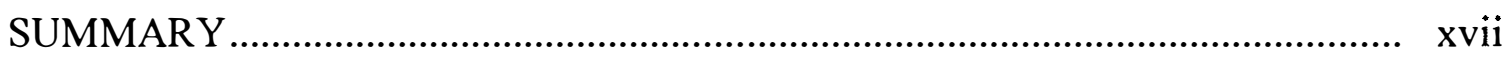

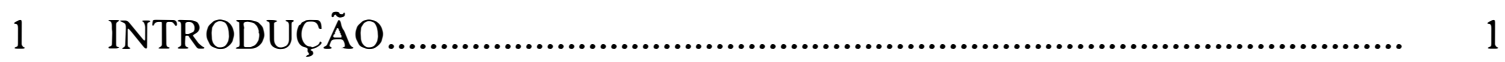

2 REVISÃO DE LITERATURA ............................................................ 4

2.1 O ambiente térmico na maternidade............................................................

2.2 Fornecimento de calor suplementar aos leitões recém-nascidos ....................... 5

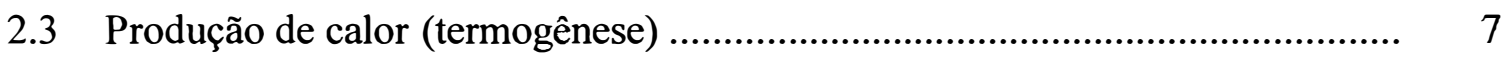

$2.4 \quad$ Perdas de calor (termólise) .......................................... 8

2.5 Tipos de sistemas de aquecimento ………………........................................ 9

2.6 Variáveis ambientais e seu(s) efeito(s) nos suínos.......................... 10

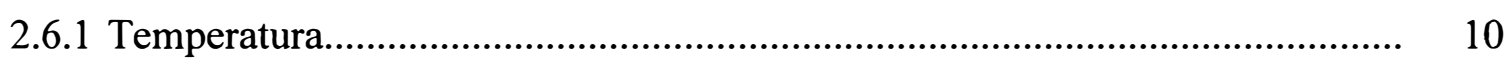

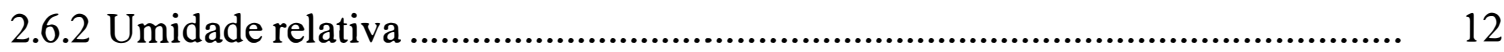

2.6 .3 Ventilação........................................................................................... 12

2.6.3.1 Tipos de ventilação .................................................................................. 13

2.6.3.1.1 Ventilação natural ou espontânea ................................................................. 13

2.6.3.1.2Ventilação artificial, mecânica ou forçada .................................................... 21

2.7 Respostas Fisiológicas ao estresse térmico …………...................................... 22

2.7.1 Temperatura de pele ............................................................................. 22

3 MATERIAL E MÉTODOS ............................................................ 25 
3.1 Características das instalações estudadas .......................................................... 25

3.2 Animais do estudo ................................................................................ 26

3.3 Condições de aberturas de entrada de ar avaliadas............................................. 27

3.4 Fontes de aquecimento estudadas...................................................................... 28

3.4.1 Lâmpadas Incandescentes............................................................................... 28

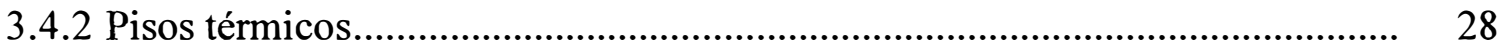

3.5 Coleta de dados ...................................................................................... 30

3.5.1 Variáveis climáticas mensuradas no interior da sala de maternidade .............. 30

3.5.2 Variáveis mensuradas no interior dos escamoteadores .................................... 31

3.5.3 Variáveis climáticas externas à sala de maternidade........................................ 32

3.5.4 Variável fisiológica dos animais .................................................................... 33

3.6 Análise de dados.................................................................................... 34

3.6.1 Análise dos dados da velocidade do vento no interior da sala de maternidade 34

3.6.2 Análise dos dados de temperatura superficial dos pisos dos escamoteadores.. $\quad 34$

3.6.3 Análise dos dados de temperatura no interior da sala ...................................... 35

3.6.4 Análise dos dados de umidade relativa do interior da sala................................ 35

3.6.5 Análise dos dados da temperatura de pele das matrizes e leitões...................... 36

$4 \quad$ RESULTADOS E DISCUSSÃO ............................................................... 37

4.1 Análise dos dados da velocidade do vento no interior da sala de maternidade 37

4.1.1 Análise descritiva .......................................................................................... 37

4.2 Análise Exploratória................................................................................... 38

4.3 Análise confirmatória ............................................................................. 42

4.4 Análise dos dados da temperatura superficial dos pisos dos escamoteadores.. $\quad 48$

4.4.1 Análise descritiva ............................................................................................ 48

4.4.2 Análise exploratória .................................................................................... 49

4.4.3 Análise confirmatória ................................................................................... 51

4.4.3.1 Análise para o dia mais frio ………………............................................... 51

4.4.3.2 Análise para o dia mais quente.................................................................. 53

4.4.3.3 Teste não-paramétrico para a locação (Teste para Medianas) da distribuição da temperatura superficial nos pisos......................................... 55 
4.5 Análise dos dados de temperatura do interior da sala ..................................... 60

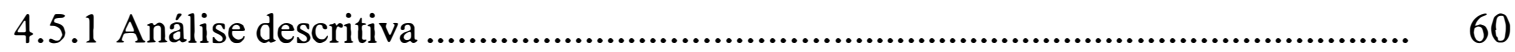

4.5.2 Análise exploratória ............................................................................... 61

4.5.3 Análise confirmatória .................................................................................. 64

4.6 Análise dos dados de umidade relativa do interior da sala................................ 67

4.6.1 Análise descritiva .................................................................................... 67

4.6.2 Análise exploratória ................................................................................... 68

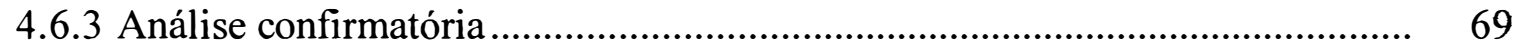

4.7 Análise dos dados da temperatura de pele das matrizes e leitões...................... 72

4.7.1 Análise descritiva ................................................................................ 72

4.7.2 Análise exploratória .................................................................................. 74

4.7.3 Análise confirmatória .............................................................................. 77

5 CONCLUSÕES GERAIS ...................................................................... 81

REFERÊNCIAS BIBLIOGRÁFICAS ........................................................... 82 


\section{LISTA DE FIGURAS}

Páginas

1 Foto demonstrativa dos constituintes de uma sala de maternidade ....................... 6

2 Deslocamento da massa de ar através de aberturas (ventilação cruzada)......... 15

3 Fluxo de ar mediante cumeeira e laterais abertas. Fonte: Abreu \& Abreu (2005) 16

4 Ventilação do ático. Fonte: Abreu \& Abreu (2005)............................................... 20

5 Esquema da localização das baias avaliadas no interior da sala de maternidade .. 26

6 Abertura lateral totalmente aberta (A) .............................................................. 27

7 Abertura lateral semiaberta (AF) ....................................................................... 27

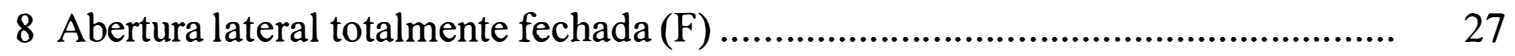

9 Localização das lâmpadas incandescentes no interior dos escamoteadores ......... 28

10 Piso pronto para ser coberto por argamassa......................................................... 29

11 Sensor de temperatura a ser embutido no piso.................................................... 29

12 Montagem do piso térmico .............................................................................. 29

13 Vista de um molde de piso térmico com o termostato....................................... 29

14 Localização dos dataloggers no interior da sala de maternidade ....................... 30

15 Representação dos pontos de coleta onde foram instalados os dataloggers....... 30

16 Termoanemômetro digital de fio quente............................................................. 31

17 Localização do datalogger no interior dos escamoteadores ................................ 31

18 Coleta das temperaturas superficiais com o Termômetro de Infravermelho ...... 32

19 Representação dos pontos de coleta da temperatura superficial dos pisos ......... 32

20 Posicionamento do datalogger para coleta de dados externos ............................. 33

21 Gráfico boxplot comparativo para a velocidade do vento $(\mathrm{m} / \mathrm{s})$ perante os diferentes dias de coleta................................................................................................... $\quad 39$ 
22 Gráfico boxplot comparativo para a velocidade do vento $(\mathrm{m} / \mathrm{s})$ perante as diferentes alturas $(\mathrm{m})$

23 Gráfico boxplot comparativo para a velocidade do vento $(\mathrm{m} / \mathrm{s})$ perante os diferentes pontos de coleta

24 Gráfico boxplot comparativo para a velocidade do vento $(\mathrm{m} / \mathrm{s})$ perante os diferentes manejos da cortina: (A) totalmente aberta, (AF) semiaberta e $(F)$ totalmente fechada

25 Interação entre os fatores manejo e altura $(\mathrm{m})$ para as médias de velocidade do vento $(\mathrm{m} / \mathrm{s})$

26 Perfil do corte longitudinal da distribuição da velocidade do vento na instalação, sobre a condição de manejo da cortina (A)

27 Perfil horizontal de distribuição da velocidade do vento na altura de $2,0 \mathrm{~m}$, para a condição de manejo da cortina (AF)

28 Perfil horizontal de distribuição da velocidade do vento na altura de $2,0 \mathrm{~m}$, para a condição de manejo da cortina $(F)$

29 Perfil do corte longitudinal de distribuição da velocidade do vento na instalação sobre a condição de manejo da cortina (AF)

30 Perfil do corte longitudinal de distribuição da velocidade do vento na instalação sobre a condição de manejo da cortina $(F)$

31 Interação dos diferentes manejos da cortina com os dias de coleta na média da temperatura superficial dos pisos $\left({ }^{\circ} \mathrm{C}\right)$

32 Representação gráfica da temperatura ambiente externa para as diversas datas avaliadas

33 Interação dos diferentes manejos da cortina com os tipos de aquecimento $(\mathrm{L}=$ lâmpada e $\mathrm{P}=$ Piso térmico) na temperatura superficial dos pisos $\left({ }^{\circ} \mathrm{C}\right)$ para $\mathrm{o}$ dia mais frio

34 Interação dos diferentes manejos da cortina com os tipos de aquecimentos na temperatura superficial dos pisos $\left({ }^{\circ} \mathrm{C}\right)$ para o dia mais quente.

35 Representação das isotermas do piso do escamoteador aquecido por lâmpada.. 59

36 Representação das isotermas do piso do escamoteador aquecido por piso térmico 59 
37 Variação da temperatura superficial em função da distância para lâmpadas incandescentes (a) e para pisos térmicos (b).

38 Gráfico boxplot comparativo para a temperatura interna em função dos diferentes dias de coleta

39 Gráfico boxplot comparativo para a temperatura interna $\left({ }^{\circ} \mathrm{C}\right)$ em função dos diferentes pontos de coleta

40 Gráfico boxplot comparativo para a temperatura interna $\left({ }^{\circ} \mathrm{C}\right)$ em função dos diferentes manejos da cortina.................................................................. 62

41 Distribuição da temperatura $\left({ }^{\circ} \mathrm{C}\right)$ ao longo dos pontos da sala de maternidade. $\quad 62$

42 Gráfico da interação dos fatores manejos da cortina e pontos de coleta para a temperatura interna $\left({ }^{\circ} \mathrm{C}\right)$................................................................... 64

43 Gráfico boxplot comparativo para a umidade relativa (\%) em função dos diferentes pontos de coleta ........................................................................................ 68

44 Gráfico boxplot comparativo para a umidade relativa (\%) em função dos diferentes manejos da cortina

45 Interação dos fatores manejos da cortina e pontos de coleta para a umidade relativa $(\%)$

46 Interação entre baias e manejos para as médias de temperatura de pele dos leitões $\left({ }^{\circ} \mathrm{C}\right)$

47 Interação entre baias e manejos para as médias de temperatura de pele das

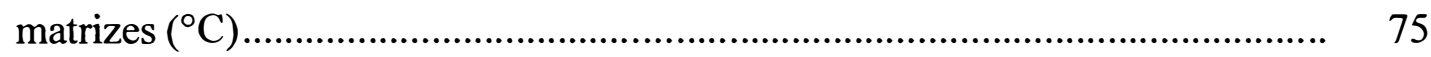

48 Gráfico boxplot comparativo para a temperatura de pele dos leitões $\left({ }^{\circ} \mathrm{C}\right)$ perante as diferentes combinações baiamanejo

49 Gráfico boxplot comparativo para a temperatura de pele das matrizes $\left({ }^{\circ} \mathrm{C}\right)$ perante as diferentes combinações baiamanejo 76

50 Interações baiamanejo na temperatura de pele dos leitões e das matrizes $\left({ }^{\circ} \mathrm{C}\right) . . \quad 80$ 


\section{LISTA DE TABELAS}

Página

1 Principais produtores mundiais de carne suína (1995-2003), em milhões de

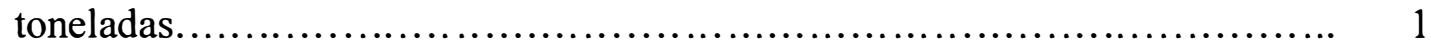

2 Evolução mundial do consumo de carnes, 1995 a 2002 ...................................... 2

3 Faixas ideais de variáveis climáticas recomendadas para cada fase de produção do suíno ......................................................................................... 11

4 Resultado da análise descritiva dos dias de coleta para a velocidade do vento no interior da sala de maternidade.

5 Resultado da análise das alturas de coleta para a velocidade do vento no interior da sala de maternidade.

6 Resultado da análise dos pontos de coleta para a velocidade do vento no interior da sala de maternidade

7 Resultado da análise dos manejos da cortina para a velocidade do vento no interior da sala de maternidade ............................................................. $\quad 38$

8 Análise de Covariância para a velocidade do vento ....................................... 43

9 Comparação das médias da velocidade do vento para os dias de coleta, através do teste de Tukey

10 Comparação das médias da velocidade do vento para as alturas de coleta, através do teste de Tukey

11 Comparação das médias da velocidade do vento para os pontos de coleta, através do teste de Tukey. 
12 Comparação das médias da velocidade do vento para os manejos da cortina, através do teste de Tukey.

13 Resultado da análise descritiva dos tipos de aquecimento: piso térmico (P) e lâmpada incandescente (L), para a temperatura superficial dos pisos.......

14 Resultado da análise descritiva dos manejos da cortina: totalmente aberto (A), semi-aberto ( $\mathrm{AF})$ e totalmente fechado $(\mathrm{F})$, para a temperatura superficial dos pisos.

15 Resultado da análise descritiva dos dias de coleta dos dados, para a temperatura superficial dos pisos

16 Resultado da Análise de Covariância para a temperatura superficial do piso.

17 Comparação das médias da temperatura superficial dos pisos para a interação dos manejos da cortina com os tipos de aquecimento, através do teste de Tukey.

18 Análise da Covariância para a temperatura do piso.

19 Comparação das médias da temperatura superficial dos pisos para a interação dos manejos da cortina com os tipos de aquecimento, através do teste de Tukey

20 Resultados do teste de Kruskal-Wallis para a distribuição da temperatura superficial nos pisos dos escamoteadores aquecidos por piso térmico.

21 Resultado do teste de Kruskal-Wallis para a distribuição da temperatura nos pisos dos escamoteadores aquecidos por lâmpadas.

22 Resultado do teste para diferentes proporções

23 Resultado da análise descritiva dos dias de coleta para a temperatura interna da sala.

24 Resultado da análise descritiva dos pontos de coleta para a temperatura interna da sala

25 Resultado da análise descritiva dos diferentes manejos da cortina para a temperatura interna da sala 
26 Resultado da Análise da Covariância para as médias da temperatura interna $\left({ }^{\circ} \mathrm{C}\right)$

27 Resultado do teste de Tukey para as médias de temperatura interna da combinação ponto-manejo.

28 Resultado da análise descritiva dos dias de coleta para a umidade relativa interna da sala

29 Resultado da análise descritiva dos pontos de coleta para a umidade relativa interna da sala

30 Resultado da análise descritiva dos diferentes manejos da cortina para a umidade relativa interna da sala

31 Resultado da Análise da Covariância para as médias da UR (\%)

32 Resultado do teste de Tukey para as médias de umidade relativa no interior da sala na combinação ponto-manejo

33 Resultado da análise descritiva da interação baia-manejo para a temperatura de pele dos leitões.

34 Resultado da análise descritiva da interação baia-manejo para a temperatura de pele das matrizes.

35 Resultado da Análise da Covariância para as médias da temperatura de pele dos leitões.

36 Resultado da Análise da Covariância para as médias da temperatura superficia das matrizes...

37 Resultado do teste de Tukey para a interação das médias baia-manejo da temperatura superficial dos leitões . 


\section{NOMENCLATURA}

Boxplot $=$ Gráfico de caixa;

$\mathrm{N}=$ tamanho da amostra;

Outlier $=$ ponto discrepante;

$\mathrm{Q} 1=$ primeiro quartil;

Q3 = terceiro quartil;

Min. = valor mínimo;

Max. = valor máximo;

$\mathrm{P}=\mathrm{p}$-valor ou valor $\mathrm{p}$;

$F=$ valor observado $p /$ a distribuição $F$;

(A) = manejo da cortina totalmente aberta;

$(A F)=$ manejo da cortina semi-aberta;

$(F)=$ manejo da cortina totalmente fechada;

$\mathrm{UR}=$ umidade relativa . 


\title{
EFEITO DO MANEJO DA VENTILAÇÃO NATURAL NO AMBIENTE DE SALAS DE MATERNIDADES PARA SUÍNOS
}

\author{
Autora: ANGÉLICA SIGNOR MENDES \\ Orientadora: Prof ${ }^{2}$. Dr ${ }^{\mathrm{a}}$. DANIELLA JORGE DE MOURA
}

\section{RESUMO}

Uma das variáveis climáticas que exerce forte influência no ambiente térmico (umidade relativa e temperatura), higiênico (gases, odores e renovação de oxigênio) e nas respostas fisiológicas e zootécnicas dos animais confinados em uma instalação é a ventilação. Assim, considerando a necessidade de proporcionar aos leitões e as matrizes um ambiente térmico adequado, o trabalho realizado teve como objetivo geral avaliar o efeito da ventilação natural no ambiente térmico de salas de maternidade para suínos, através de mudanças microclimáticas induzidas por diferentes aberturas para entrada de ar. E, como objetivos específicos: 1) Mapear as variáveis climáticas resultantes (temperatura, velocidade do ar e umidade relativa) de diferentes aberturas para entrada de ar em salas de maternidade para suínos; 2) Avaliar o efeito da ventilação natural em escamoteadores equipados por dois tipos de fontes de aquecimento: piso térmico e lâmpada incandescente; e 3) Mensurar a variação das temperaturas de pele de matrizes e leitões em função das diferentes aberturas para entrada de ar. A pesquisa foi desenvolvida na sala da maternidade da Granja Querência, propriedade cuja principal atividade é a produção industrial de suínos, localizada no município de Elias Fausto, SP. Estudaram-se e mensuraram-se alterações nas seguintes variáveis: umidade relativa, 
temperatura de bulbo seco e velocidade do ar no interior do galpão; temperatura de bulbo seco, umidade relativa e temperatura superficial do piso de escamoteadores equipados com diferentes fontes de aquecimento: lâmpadas incandescentes e pisos térmicos; e temperatura de pele das matrizes e leitões, sob três condições distintas de manejo da ventilação natural: cortina totalmente aberta (A), semi-aberta (AF) e totalmente fechada (F). $\mathrm{Na}$ análise da velocidade do vento no interior da sala de maternidade encontrou-se que a altura de $1,0 \mathrm{~m}$ acima do piso apresentou significativamente a menor média de velocidade do vento quando comparada com as alturas 2,0 e $3,0 \mathrm{~m}$. Houve diferença significativa da velocidade do vento entre os manejos da cortina (A) e (AF) com o manejo (F) e, também, entre os pontos de coleta da velocidade do vento. A distribuição da temperatura ao longo dos pisos dos escamoteadores aquecidos por lâmpadas apresentou uma maior variação espacial do que para os pisos dos escamoteadores aquecidos por pisos térmicos e ambos sofreram influência significativa da temperatura ambiente. Analisando o efeito dos manejos da cortina na temperatura no interior da sala observou-se que o manejo $(\mathrm{F})$ produziu as maiores médias de temperatura e as menores médias de umidade relativa. Quanto à temperatura de pele das matrizes observou-se que as condições de manejo da cortina $(F)$ e (AF) provocaram as maiores médias de temperatura. Já para os leitões, observaram-se sempre maiores médias de temperatura de pele em comparação com as matrizes, porém sem sofrer influência significativa dos manejos da cortina. Concluiu-se que os diferentes manejos da cortina em salas de maternidade para produção intensiva de suínos influenciaram significativamente o ambiente térmico resultante, afetando a distribuição da temperatura, umidade relativa e velocidade do vento no interior da sala de maternidade, a distribuição da temperatura de superfície dos pisos dos escamoteadores aquecidos por pisos térmicos e lâmpadas incandescentes e a temperatura de pele das matrizes. 


\title{
NATURAL VENTILATION MANAGEMENT EFFECT IN SOW'S NURSING HOUSING
}

\author{
Author: ANGÉLICA SIGNOR MENDES \\ Adviser: Prof ${ }^{a}$. Dr ${ }^{2}$. DANIELLA JORGE DE MOURA
}

\section{SUMMARY}

One of the variables that have strong influence in the final thermal environment (relative humidity and ambient temperature); hygiene (gases, odors and oxygen renovation); and in the productive response of confined animal's is the ventilation. Considering the need to offer the piglets and female breeder adequate environment the research had the aim of evaluating the effect of natural ventilation in the thermal ambient of nursing sows room, through internal microclimate modifications induced by distinct air openings. The specific objectives are: 1) to map resulting climatic variables (temperature, wind speed and relative humidity) of distinct air openings inside nursing sows rooms; 2) to evaluate the effect of natural ventilation in creep zone using two distinct heat sources: heat mat and use of incandescent lamp; 3) to measure the sows and piglets skin temperature variation as function of the distinct openings. The research was developed in the sows nursing room of Querência farm which the main activity is swine industrial production, and is located at Elias Fausto County, São Paulo state. Inside environment variations (relative humidity, dry bulb temperature and wind speed inside the room; dry bulb temperature, relative humidity and creep floor surface temperature with distinct floor heat source: heat mat and incandescent lamp; and skin temperature of 
sows and piglets) were measured and their effect induced by distinct openings: totally open curtain (A); semi-open curtain (AF); and totally open (F) were studied. It was found that at a height of $1.0 \mathrm{~m}$ above the sows nursing room's floor the wind speed presented the smallest significant value when compared to $2.0 \mathrm{~m}$ and $3.0 \mathrm{~m}$ height. It was found that the wind speed values were significantly scattered distributed around the room. There was significant difference between the wind speed values related to managements A and AF, when compared to management F. Analyzing the creep floor temperature it was found significant difference between the managements used for the cooler days and the one used for the warmers days. The temperature distribution along the incandescent lamp heated creep floors presented higher spatial variation when compared to heat mat flooring. Analyzing the curtain management effect on the room temperature it was observed that the $\mathrm{F}$ management produced the highest average temperature as well the smallest relative humidity values. Regarding the sows skin temperature it was found that the curtain management $\mathrm{F}$ and $\mathrm{AF}$ led to highest average temperature values. For the piglets it was observed that higher skin temperature was found when comparing to the sows, however having direct influence of the curtain management. It was concluded that the curtain management in sows nursing room in industrial swine production influenced significantly the resulting thermal environment affecting the temperature distribution, as well as the relative humidity and wind speed. It also influenced the distribution of the heated creep floor surface temperature and the sows skin temperature. 


\section{INTRODUÇÃO}

A suinocultura é uma atividade que exige muita dedicação do criador para alcançar bons índices de produtividade e, em conseqüência, resultados econômicos satisfatórios. Fatores ambientais externos e o microclima dentro das instalações exercem efeitos diretos e indiretos sobre a produção de suínos, acarretando a redução da produtividade, com conseqüentes prejuízos econômicos à produção.

O Brasil é o único país da América do Sul entre os dez maiores produtores de carne suína (Tabela 1). Sua posição é crescente, ganhando posições ano após ano, e até o final desta década, deverá tornar-se membro do seleto grupo dos quatro maiores produtores mundiais.

Tabela 1. Principais produtores mundiais de carne suína (1995-2003), em milhões de toneladas

\begin{tabular}{lcccc}
\hline & $\mathbf{1 9 9 5}$ & $\mathbf{2 0 0 2}$ & Crescimento \% & $\mathbf{2 0 0 3}$ \\
\hline 1. China & 33,401 & 44,599 & 33,52 & 44.70 \\
2. Estados Unidos & 8,097 & 8,937 & 10,37 & 8.760 \\
3. Alemanha & 3,602 & 4,122 & 14,43 & 4.160 \\
4. Espanha & 2,174 & 2,985 & 37,30 & 3.080 \\
5. Brasil & 1,430 & 2,860 & 100,0 & 2.696 \\
6. França & 2,144 & 2,350 & 9,61 & 2.380 \\
7. Canadá & 1,275 & 1,835 & 43,92 & 1.865 \\
8. Dinamarca & 1,494 & 1,760 & 17,80 & 1.800 \\
9. Polônia & 1,962 & 1,710 & $-14,7$ & 1.640 \\
10. Rússia & 1,865 & 1,595 & $-16,9$ & 1.700 \\
Total 10 maiores & 57,444 & 72,753 & 26,6 & 72.198 \\
Total Mundial & 78,534 & 94,185 & 19,9 & - \\
10 maiores/Total & $73,1 \%$ & $77,2 \%$ & - & - \\
Mundial & & & & \\
\hline
\end{tabular}

Fonte: Anuário Pork World (2004). 
Analisando-se o período de 1995 a 2002, a carne suína ficou em segundo lugar no quesito consumo mundial de carnes, com um crescimento de 8,4 \%. Esses dados podem ser visualizados na Tabela 2.

Tabela 2. Evolução mundial do consumo de carnes, 1995 a 2002

\begin{tabular}{lccc}
\hline Carne & $\mathbf{1 9 9 5} \mathbf{( k g / \text { pessoa } )}$ & $\mathbf{2 0 0 2} \mathbf{( k g / \text { pessoa) }}$ & Crescimento \% \\
\hline Suíno & 13,89 & 15,06 & 8,42 \\
Frango & 9,66 & 11,80 & 22,15 \\
Bovino & 10,07 & 9,75 & $-3,28$ \\
Outros & 2,58 & 2,56 & $-0,78$ \\
Total & 36,20 & 39,17 & 8,20 \\
\hline
\end{tabular}

Fonte: Anuário Pork World (2004).

Uma das mudanças mais evidentes na suinocultura brasileira, e mundial, é a tendência linear observada na diminuição do número de sistemas de produção em funcionamento, paralela a um aumento no número de animais produzidos em cada um desses sistemas.

O comportamento cíclico do mercado de suínos exige que se busque êxito e lucratividade na produção, vinculado a variáveis como disponibilidade financeira, mão de obra especializada, qualidade produtiva e reprodutiva dos animais e manejo empregado. Cada uma das variáveis tem sua importância, sendo decisivo considerá-las de forma interdisciplinar. O fator econômico e principalmente o investimento inicial, é importante, podendo-se minimizá-lo com alternativa nas técnicas empregadas, que possibilitarão melhora no desempenho do plantel ao alcançarem-se melhores valores na relação custobenefício (Reis, 1995).

Na suinocultura, a maternidade é o setor mais detalhado e complexo a ser projetado, pois os leitões recém nascidos requerem altas temperaturas ambientais para prevenir excessivas perdas de calor dos seus corpos, porém temperaturas ambientais mais baixas são desejáveis para o conforto das matrizes. Portanto, é comum a adoção de práticas que 
promovam calor localizado para os leitões enquanto se mantêm temperaturas inferiores para as matrizes nas maternidades.

Uma das variáveis climáticas que exerce forte influência no ambiente térmico (umidade e temperatura), higiênico (gases, odores e renovação de oxigênio) e nas respostas fisiológicas e zootécnicas dos animais confinados em uma instalação é a ventilação. Sobre o aspecto de manejo da ventilação, outono e primavera são os períodos mais dificeis do ano, porque apresentam freqüentes mudanças significativas na temperatura, velocidade do ar e na umidade relativa (Knízková et al., 2002).

$\mathrm{O}$ ambiente interno das edificações, muitas vezes reflete as necessidades térmicas dos tratadores entrando em confronto com as necessidades térmicas dos animais confinados, que na maioria das vezes, são muito distintas. Em geral, a literatura sobre os sistemas de ventilação forçada é bastante detalhada e ampla, tanto na teoria como em aplicações a campo, entrando em contraste com o corpo de literatura sobre sistemas de ventilação natural, que é escasso e precariamente definido. Essa falta de informação sobre a ventilação natural, explica porque, freqüentemente, os tratadores interferem no manejo da ventilação natural nas instalações e como criam um microclima que pode ser inadequado aos animais.

Assim, considerando a necessidade de fornecer informações aos produtores e proporcionar aos leitões e as porcas um ambiente térmico adequado, o trabalho realizado teve como objetivo geral avaliar o efeito da ventilação natural no ambiente interno de salas de maternidade para suínos, através de mudanças microclimáticas induzidas por diferentes aberturas para entrada de ar.

E, como objetivos específicos:

1) Mapear as variáveis climáticas resultantes (temperatura, velocidade do ar e umidade relativa) de diferentes aberturas para entrada de ar em salas de maternidade para suínos;

2) Avaliar o efeito da ventilação natural em escamoteadores equipados por dois tipos de fontes de aquecimento: piso térmico e lâmpada incandescente;

3) Mensurar a variação das temperaturas de pele de matrizes e leitões, em relação às diferentes aberturas para entrada de ar. 


\section{REVISÃO DE LITERATURA}

\subsection{O ambiente térmico na maternidade}

Os suínos, por suas características fisiológicas, possuem dificuldades de se adaptar às flutuações térmicas ambientais e a faixa de temperatura para seu conforto varia com a idade. Conforme Comberg (1966) a temperatura ideal é de 32 a $30^{\circ} \mathrm{C}$ para leitões de zero a duas semanas de vida; de 28 a $25^{\circ} \mathrm{C}$ para leitões de três a quatro semanas; e 18 a $15^{\circ} \mathrm{C}$ para leitões com mais de quatro semanas de vida.

Há algumas alternativas para a minimização de efeitos negativos nas altas temperaturas da maternidade, para tanto é necessária uma atenção individualizada à matriz, de maneira a protegê-la da exposição às máximas temperaturas ambientais sem afetar os leitões (Nääs, 1999).

O leitão recém-nascido possui os sistemas de termorregulação e imunitário pouco desenvolvidos, tornando-se sensível às temperaturas ambientais baixas. Nestas condições o leitão reduz sua atividade motora e, conseqüentemente, diminui a ingestão de colostro, acarretando maior incidência de doenças, maior número de leitões esmagados e alta taxa de refugos na desmama, sendo necessário alguns cuidados especiais. A regra básica é fornecer aos leitões um ambiente limpo, desinfetado, seco e aquecido $\left(32^{\circ} \mathrm{C}\right)$. O que significa investir em piso adequado e sistemas de aquecimento (Perdomo, 1987).

Durante a vida uterina, a temperatura corporal do leitão é bastante alta e constante, em comparação com a vida extra uterina. Ao nascer, o leitão está neurologicamente bem desenvolvido, porém fisiologicamente ainda é considerado imaturo e sua capacidade de controlar eficientemente a temperatura corporal está pouco desenvolvida, não podendo 
compensar imediatamente a intensa perda de calor logo após o parto (Sobestiansky et al., 1998).

A temperatura corporal do recém-nascido cai de 1,7 a $6,7{ }^{\circ} \mathrm{C}$ (em média $2,2{ }^{\circ} \mathrm{C}$ ), logo após o parto. O tempo que o leitão leva para alcançar novamente valores fisiológicos normais de temperatura corporal depende diretamente da temperatura ambiente, de seu peso corporal e do momento em que começa a mamar (Bäckström \& Curtis, 1981).

\subsection{Fornecimento de calor suplementar aos leitões recém-nascidos}

Quando a temperatura ambiental é muito baixa, o recém-nascido perde calor e sua temperatura corporal cai rapidamente. Isso se deve, não só à incapacidade de regular eficientemente sua temperatura corporal, mas também ao fato de o leitão apresentar um revestimento de cerdas relativamente espaçadas, não podendo impedir o fluxo de calor através de piloereção, e por não possuir a camada de tecido gorduroso subcutâneo, que reduz o fluxo de calor desde os vasos sanguíneos até a superfície da pele (Simmons, 1976).

O aumento da taxa metabólica do leitão se deve ao fato do animal ter que usar grande parte de sua produção de energia para se manter aquecido, em vez de usá-la para o crescimento, piorando sua taxa de conversão. Além disso, essa perda no crescimento também limita o desenvolvimento da gordura, a qual, como camada subcutânea, aumenta o isolamento térmico do animal (Blair et al., 1976).

O frio contínuo ou intermitente aumenta a suscetibilidade dos leitões a infecções enterotoxigênicas de Escherichia coli e ao vírus da Gastroenterite Transmissível. Essa redução da resistência é causada, provavelmente, por mudanças na função imune induzidas pelo estresse. O aumento do cortisol no plasma, provocado por resfriamento, é um importante indicador fisiológico, podendo causar essas mudanças na resistência dos leitões às doenças infecciosas. Dependendo da intensidade da perda de calor, ocorre também morte por hipoglicemia ou predisposição à morte por esmagamento (Kelly, 1982). 
Como dito anteriormente, na maternidade o controle das condições ambientais é mais complexo que nas demais instalações. O projeto deve atender a microambientes específicos para as matrizes e para os leitões, além de protegê-los contra possível esmagamento. Para evitar o esmagamento, normalmente, são projetadas gaiolas, com proteções e delimitações de áreas destinadas aos leitões, que possibilitam pouco movimento à fêmea (Figura 1). Para o conforto térmico dos leitões, deve-se manter um abrigo (escamoteador), vedado e aquecido por meio de lâmpadas, resistências elétricas ou pisos térmicos, procurando manter no seu interior um ITGU (Índice de temperatura de globo e umidade) entre 82 e 84, enquanto que na maternidade o ITGU não deve ultrapassar a 72 (Nechoechea, 1996). No interior da maternidade, também é necessária uma adequada ventilação $\left(6 \mathrm{~m}^{3} \cdot \mathrm{s}^{-1}\right.$. animal $\left.{ }^{-1}\right)$ para uma velocidade do ar de $0,3 \mathrm{~m} \cdot \mathrm{s}^{-1}$, que possibilite: a) eliminar o excesso de umidade do ambiente, proveniente da água liberada pela respiração dos animais e dos dejetos; b) renovar o ar viciado, favorecendo a entrada de ar puro; c) eliminar a amônia que desprende dos dejetos; d) reduzir a temperatura ambiente; e) aumentar a dissipação de calor por radiação e convecção pelas matrizes (Morrison et al., 1976; Vaquero, 1981; Dividich \& Rinaldo, 1989; Scott et al., 1983).

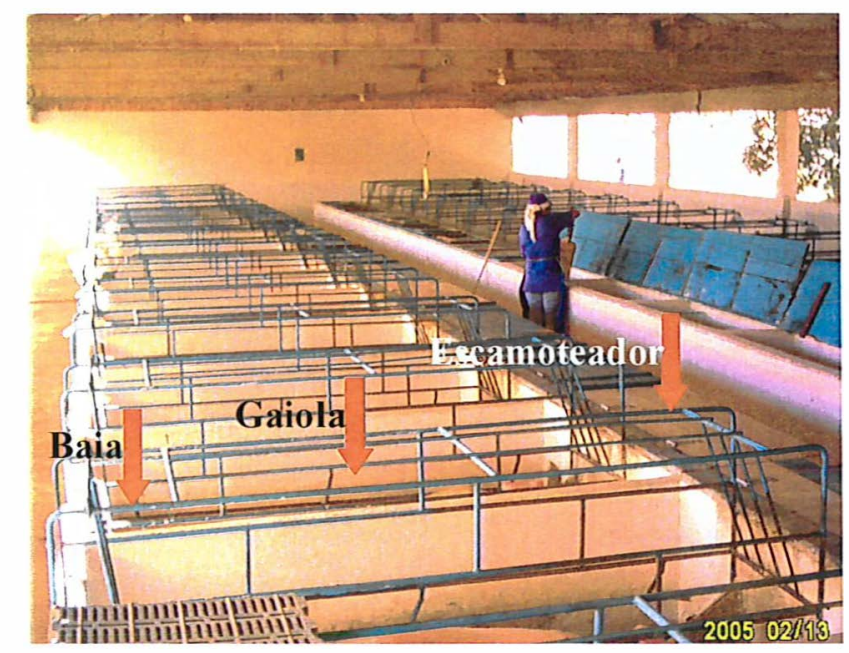

Figura 1 - Foto demonstrativa dos constituintes de uma sala de maternidade 
Desta forma o conhecimento sobre a movimentação de ar e transferência de calor convectivo dentro e ao redor do escamoteador é importante para a otimização da configuração desse microambiente.

\subsection{Produção de calor (termogênese)}

Um dos fatores mais importantes na variação da termogênese no suíno é a temperatura ambiente.

O suíno por ser homeotérmico mantém sua temperatura interna dentro dos limites estreitos de variações significativas de temperatura ambiente (Cossin \& Bowler, 1987). Esta manutenção da temperatura corporal mais ou menos constante é permitida pela termorregulação a qual assegura o equilíbrio dinâmico entre o calor produzido pelo organismo (produção de calor ou termogênese), e cedido ao meio ambiente (perdas de calor ou termólise).

Segundo Henken (1993), as condições climáticas exercem uma grande influência na produção de calor pelo animal, a qual é proveniente dos processos metabólicos associados à manutenção, crescimento e reprodução dos animais.

Conforme Holmes \& Close (1977), a produção de calor é expressa em relação à massa metabólica do animal. Mais recentemente, Sallvik \& Pedersen (1999) desenvolveram equações que expressam a produção total de calor para diferentes fases de criação de suínos, expressadas em relação à ingestão diária de energia pelos alimentos (W), dissipação total de calor do animal na instalação (W), dissipação de calor devido a mantença $(\mathrm{W})$, peso do animal $(\mathrm{kg})$ e coeficiente da eficiência do ganho de peso.

Nienaber \& Hahn (1988), estimaram a relação entre a produção de calor em suínos com peso vivo compreendido entre 40 e $90 \mathrm{~kg}$ e temperatura ambiente variando entre 5 e $30^{\circ} \mathrm{C}$.

Conforme Mount (1979) a produção de calor de suínos em fase de crescimento deve ser referida também à quantidade de alimento ingerido, sendo afetada pela ingestão de energia na zona de termoneutralidade. Abaixo desta zona, a produção de calor é determinada principalmente pela reação dos animais à temperatura ambiente. 


\subsection{Perdas de calor (termólise)}

A temperatura é o fator fundamental na determinação da taxa de perda de calor pelo suíno. Dentro da zona de termoneutralidade o plano nutricional tem um efeito importante, pois à medida que a ingestão alimentar aumenta, a produção de calor também aumenta e conseqüentemente as necessidades de dissipação de calor. Abaixo da zona de termoneutralidade, a temperatura ambiente é o fator primário, pois à medida que esta diminui, aumentam as perdas de calor (Close et al., 1971).

As perdas de calor, por sua vez, processam-se por duas vias: via sensível e via latente. Os mecanismos de transferência de calor sensível ocorrem em três processos: condução, convecção e radiação, que seguem as leis da física. Como o suíno não possui glândulas sudoríparas funcionais, recorre a dois processos básicos para a liberação de calor latente: a respiração ou passagem de água através da pele e a evaporação de água proveniente dos dejetos líquidos ou existente sobre os pavimentos em que se deitam. Para Ingram (1965), o suíno é uma das espécies que registram menores perdas de água através da pele, em situações de altas temperaturas ambientais, motivo pelo qual o ofego torna-se dominante na liberação de calor nestas condições de temperatura (Meneses, 1985).

Bruce \& Clark (1979), encontraram que em condições de termoneutralidade as perdas por radiação e por convecção são mais importantes. Quando a temperatura sobe acima da temperatura crítica superior, as perdas de calor latente aumentam com o incremento da temperatura ambiente, podendo, para valores baixos de temperatura ambiente, tornarem-se constantes.

As perdas de calor sensível dependem fundamentalmente do gradiente de temperatura entre a superfície do animal e o ambiente, a medida que estas temperaturas se aproximam por aumento da temperatura ambiente, o fluxo de calor sensível vai diminuindo. $\mathrm{O}$ animal no intuito de aumentar as suas perdas de calor, para manter sua temperatura corporal constante, passa a utilizar as vias evaporativas de perda de calor. 


\subsection{Tipos de sistemas de aquecimento}

Segundo Zhang \& Xin (2000), existem duas formas típicas de aquecimento localizado para os leitões, sendo elas o calor radiante (comumente gerado por lâmpadas) e o calor de superfície condutivo (obtido nos pisos térmicos). Embora a maioria dos produtores de suínos na América do Norte e do Sul utilizem sistemas de aquecimento por lâmpadas, o sistema de aquecimento por superfície, está ganhando maior aceitação atualmente.

Uma das vantagens do aquecimento por superficie é promover uma temperatura mais uniforme na área de descanso do suíno do que o aquecimento por energia radiante (lâmpadas), devido ao processo de condução piso-leitão, como pode ser observado pelas pesquisas realizadas por Zhang \& Xin (2001) e Pandorfi (2002).

Os pisos térmicos são construídos com materiais sólidos ou tábuas flexíveis com elementos de aquecimento embutidos. Foram considerados pela indústria de suínos na América do Norte e na Europa como uma alternativa eficiente de aquecimento. A fonte de calor para aquecer pisos térmicos é tipicamente formada por elementos de aquecimento elétricos embutidos ou circulação de água quente. Pisos térmicos elétricos são fáceis de instalar dentro de qualquer instalação já existente, para substituir as lâmpadas de aquecimento. Um tamanho comercial típico deste piso é de $0,3 \mathrm{~m} \times 1,2 \mathrm{~m}$ (depende do tamanho do escamoteador) e consome 60 a $125 \mathrm{~W} / \mathrm{h}$ de eletricidade, demonstrando um consumo de energia inferior ao sistema provido por lâmpadas de aquecimento (175 - 250 $\mathrm{W} / \mathrm{h})$.

O desempenho térmico dos pisos varia consideravelmente, dependendo da sua utilização (Zhang \& Xin, 2000). Há poucas informações na literatura sobre como projetar e utilizar pisos térmicos. Xin \& Zhang (1999) estudaram a preferência dos leitões por lâmpadas de aquecimento ou por pisos térmicos, quando submetidos a diferentes condições ambientais e revelaram que o piso térmico de maneira geral foi preferido pelos leitões. Resultados semelhantes foram obtidos por Pandorfi (2002).

Zhang \& Xin (2001) relataram que a temperatura de pele de leitões de 2 a 9 dias de vida deitados nos pisos térmicos foi $34,6^{\circ} \mathrm{C}$. Para um grupo de leitões de mesma idade, 
sobre idênticas condições ambientais, a temperatura da pele dos leitões foi de $39,5^{\circ} \mathrm{C}$ quando os leitões estavam deitados diretamente sob a lâmpada e $33,4^{\circ} \mathrm{C}$ quando deitados a $60 \mathrm{~cm}$ do centro da área de projeção da lâmpada. A temperatura da pele dos leitões decresceu rapidamente com a distância do centro da área de projeção da lâmpada nos primeiros $28 \mathrm{~cm}$.

\subsection{Variáveis ambientais e seu(s) efeito(s) nos suínos}

Estudos têm demonstrado que o desempenho térmico das instalações comumente utilizadas pelos produtores vem apresentando um quadro de desconforto ambiental, associado a altas temperaturas, altas umidades relativas e ventilação deficiente. Esse quadro torna-se responsável por uma queda na qualidade do ar, culminando em um aumento na incidência de doenças do rebanho e conseqüente queda na produtividade (Perdomo, 1995).

\subsubsection{Temperatura}

O ambiente térmico ótimo para um animal é denominado de zona de conforto térmico ou zona de termoneutralidade, a qual ocorre quando a produção de calor é transferida ao ambiente sem requerer ajustes dos mecanismos homeotérmicos do próprio animal (ASHRAE , 1985).

A temperatura crítica marca o limite da zona de termoneutralidade, abaixo ou acima da qual, o suíno precisa ganhar ou perder calor para manter-se em condições de termoneutralidade.

O suíno é uma espécie animal com mecanismos fisiológicos pouco eficientes para a eliminação do calor corporal. Turco, citado por Moura (1999), estudando os efeitos da temperatura desde 25 até $43^{\circ} \mathrm{C}$ com $50 \%$ de umidade relativa, sobre o desempenho de suínos em várias faixas de peso, desde 45 até $160 \mathrm{Kg}$, verificou que, quanto mais pesado o animal, maior sua sensibilidade ao calor, sendo assim, suínos em terminação exigem as menores temperaturas de conforto. As temperaturas ótimas para 
suínos na fase de acabamento podem ser consideradas de uma forma geral entre 12 a $21^{\circ} \mathrm{C}$ (Perdomo, 1995) e a umidade relativa por volta de $70 \%$. Já leitões recém-nascidos possuem uma temperatura crítica da ordem de $32^{\circ} \mathrm{C}$, de acordo com Svendsen \& Bille (1981).

De acordo com Lee \& Phillips (1948), os suínos são os mais sensíveis a altas temperaturas dentre os animais domésticos. Isso se deve ao seu metabolismo elevado, à capa de tecido adiposo que possuem, além de seu sistema termorregulatório pouco desenvolvido. Os suínos não suam, quando sua temperatura retal atinge $44,4^{\circ} \mathrm{C}$, eles morrem por hipertermia. A conversão alimentar e a taxa diária de ganho de peso para suínos em crescimento são afetadas pela temperatura do ar. Temperaturas entre $15 \mathrm{e}$ $21^{\circ} \mathrm{C}$ produzem as máximas taxas de ganho de peso. A conversão alimentar de suínos declina a partir de temperaturas maiores que $15^{\circ} \mathrm{C}$ (ASHRAE, 1985).

As faixas ideais de temperatura recomendadas para suínos em várias idades são mostradas na Tabela 3.

Tabela 3. Faixas ideais de variáveis climáticas recomendadas para cada fase de produção do suíno

\begin{tabular}{lccc}
\hline Fase de Produção & $\begin{array}{c}\text { Temperatura } \\
\left({ }^{\circ} \mathrm{C}\right)\end{array}$ & $\begin{array}{c}\text { Umidade Relativa } \\
(\%)\end{array}$ & $\begin{array}{c}\text { Entalpia } \\
(\mathrm{KJ} / \mathrm{kg} \mathrm{de} \text { ar seco })\end{array}$ \\
\hline Cobertura & $18-21$ & $50-70$ & $60,440-68,619$ \\
Gestação & $18-20$ & $50-70$ & $55,450-63,069$ \\
Maternidade & $16-18$ & $50-70$ & $46,424-55,450$ \\
Pré-creche & $22-25$ & $50-70$ & $71,551-81,040$ \\
Creche & $18-21$ & $50-70$ & $60,440-68,619$ \\
Terminação & $18-21$ & $50-70$ & $60,440-68,619$ \\
\hline
\end{tabular}

Fonte: Moura (1999). 


\subsubsection{Umidade relativa}

O limite de tolerância dos suínos à umidade está intimamente ligado à temperatura ambiental já que as taxas elevadas de umidade relativa, diminuem a capacidade de dissipação do calor corporal por meios evaporativos de suínos submetidos à altas temperaturas.

A umidade relativa também está associada com a viabilidade de agentes infecciosos nas partículas aerolizadas. Pesquisadores como Veit \& Troutt (1982), sugerem valores ótimos de umidade relativa entre 50 e $75 \%$.

De acordo com Morrison (1969), a umidade do ar influenciando nas perdas evaporativas de calor, particularmente pelos pulmões, afeta o ganho de peso dos animais quando a temperatura ambiente se encontra acima das temperaturas recomendadas aos suínos. A umidade afeta o consumo de alimentos em temperaturas altas, porém não afeta a eficiência alimentar exceto em condições extremas. O fator umidade possui pouca influência também na temperatura retal e na temperatura de pele em suínos.

\subsubsection{Ventilação}

A velocidade do vento exerce pouco efeito sobre a perda de calor dos suínos por convecção, quando a temperatura ambiente se encontra acima da temperatura de termoneutralidade, porém é favorecida a perda de calor metabólico na forma latente.

Em porcas gestantes, no final da gestação, quando expostas a temperaturas acima de $30^{\circ} \mathrm{C}$ com baixa ventilação (velocidades de vento da ordem de $1,5 \mathrm{~m} / \mathrm{s}$, por ventilação natural), tem a sua freqüência respiratória elevada em, aproximadamente, 20 vezes quando comparada com porcas em ambientes bem ventilados (velocidade do vento acima de $5 \mathrm{~m} / \mathrm{s}$ ). Embora no início da gestação não se apresentem resultados tão expressivos, há uma forte evidência que altas temperaturas ambientes resultam em aumento do número de leitões mumificados, ou mesmo na redução do número de nascidos vivos (Moura, 1999). 
De maneira geral, a recomendação para a velocidade que incide diretamente sobre os animais, é de 0,1 a $0,2 \mathrm{~m} / \mathrm{s}$ para leitões lactantes e de 0,1 a $0,3 \mathrm{~m} / \mathrm{s}$ para porcas em lactação. Porém a quantidade de ar que o sistema de ventilação deve introduzir ou extrair do galpão depende das condições meteorológicas e da idade dos animais. A capacidade de ventilação em metros cúbicos por segundo determina o ritmo de renovação do ar desejado.

Controlando-se convenientemente a entrada de calor na edificação, bem como facilitando a saída do calor produzido, a ventilação passa a ser uma complementação dos requisitos de conforto.

\subsubsection{Tipos de ventilação}

A ventilação proporciona a renovação do ar ambiente, sendo de grande importância para a higiene em geral e para o conforto térmico de verão em regiões de clima temperado e de clima quente e úmido. A ventilação é descrita em dois tipos: ventilação natural ou espontânea, que se divide em ventilação dinâmica e térmica e ventilação artificial, mecânica ou forçada, que se divide em pressão positiva (pressurização) e pressão negativa (exaustão).

\subsection{Ventilação natural ou espontânea}

A ventilação natural é o deslocamento do ar através do edificio, através de aberturas, umas funcionando como entrada e outras, como saída. Assim, as aberturas para ventilação deverão ser dimensionadas e posicionadas de modo a proporcionar um fluxo de ar adequado ao recinto. O fluxo de ar que entra ou sai do edifício depende da diferença de pressão do ar entre os ambientes internos e externos, da resistência ao fluxo de ar oferecida pelas aberturas, pelas obstruções internas e de uma série de implicações relativas à incidência do vento e forma do edificio (Frota \& Shiffer, 1995).

A ventilação natural permite alterações e controle da pureza do ar, provendo a instalação de oxigênio, eliminando amônia, $\mathrm{CO}_{2}$ e outros gases nocivos, excesso de 
umidade e odores (ventilação higiênica), possibilitando também, dentro de certos limites, controlar a temperatura e a umidade do ar nos ambientes habitados (ventilação térmica), de tal forma que o ar expelido, quente e úmido, seja substituído e assim aumente a perda calorífica por convecção.

A ocupação da edificação por pessoas, animais, máquinas e equipamentos e a exposição à radiação solar vão ocasionar, nos ambientes internos, temperaturas superiores às do ar externo. Esse acréscimo de temperaturas, no caso de inverno nos climas quentes ou no caso geral de climas frios, pode ser um fator positivo, porém, na época de verão dos climas temperados ou durante todo o ano em climas quentes certamente será um fator negativo, agravante das condições térmicas ambientais.

A ventilação natural pode ocorrer em razão das diferenças de pressão causadas pela ação dinâmica do vento (ventilação dinâmica) ou em razão das diferenças de temperatura entre dois meios considerados (ventilação térmica). Isto significa que as forças naturais disponíveis para mover o ar no entorno, através e dentro das construções

são as forças do vento e as diferenças de temperatura. Às vezes, os dois fatores podem agir em conjunto (Baêta \& Souza, 1997).

\section{a) Ventilação dinâmica}

O ar flui sempre de um ponto de alta pressão para um ponto de baixa pressão. A ação dos ventos, embora intermitente, ocasiona o escalonamento das pressões no sentido horizontal. Quando uma corrente de ar perde velocidade a pressão sobe. Quanto maior a diferença de pressão maior será a velocidade do ar (Abreu \& Abreu, 2005).

A ventilação dinâmica é intensificada por meio de aberturas, dispostas convenientemente em paredes opostas e na direção dos ventos dominantes. A taxa em que a ventilação natural ocorre depende da velocidade do vento, da sua direção, da proximidade e das dimensões de obstáculos, como árvores ou construções, da forma e localização das aberturas de entrada e saída do ar.

O modelo da movimentação do ar em uma edificação une o conhecimento entre o sistema de ventilação e o microclima ao redor da instalação. Um estudo realizado por 
Randall (2003), mostrou que um dos principais fatores governantes dos modelos de vazão de ar deriva de regras qualitativas pelas quais o modelo da movimentação do ar pode ser predito. Concluiu também que o ar se desloca em uma série de movimentos rotacionais produzido por obstáculos no caminho da entrada das correntes de ar e por correntes de convecção ao redor da instalação.

Conforme Van Wagnenberg \& Smolders (2000), em uma perfeita mistura do ar no interior de uma edificação, a eficácia da ventilação será igual em todos os pontos. Entretanto, na prática, todos os pontos de ventilação de ar mostram gradientes em algumas variáveis como temperatura, umidade, gases e poeira.

Como o ar se desloca dos pontos de maior para os de menor pressão, se existirem aberturas na edificação, a pressão positiva forçará a massa de ar a entrar pelas aberturas e a negativa a sair (Figura 2). Nada adianta ter aberturas em um mesmo plano já que as pressões, sendo iguais, não provocam a circulação do ar. Esse tipo de ventilação natural é conhecida como ventilação cruzada (Abreu \& Abreu, 2005).

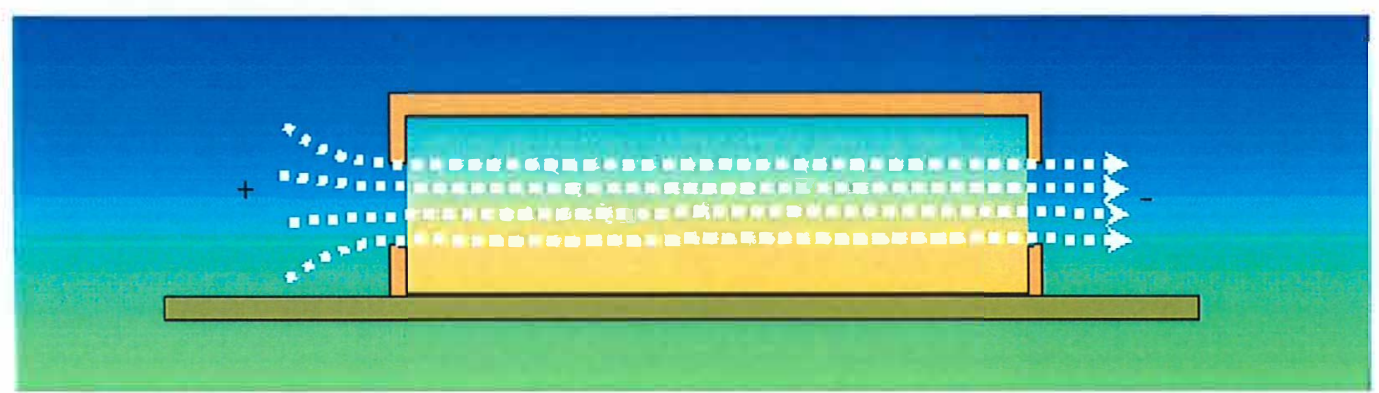

Figura 2 - Deslocamento da massa de ar através de aberturas (ventilação cruzada). Fonte: Abreu \& Abreu (2005)

Com a ventilação natural na edificação, mediante abertura da cumeeira e aberturas laterais, se a pressão negativa na cumeeira é maior que a pressão negativa no lado do sotavento, o ar flui desse último para a cumeeira aberta (Figura 3). 


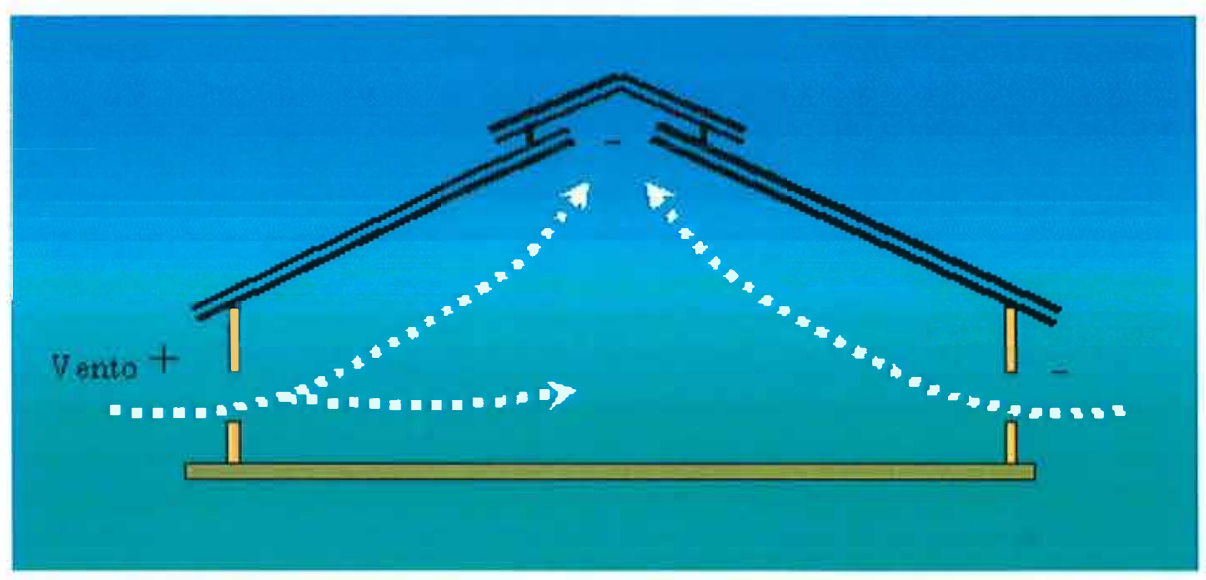

Figura 3 - Fluxo de ar mediante cumeeira e laterais abertas. Fonte: Abreu \& Abreu (2005)

Muitos pesquisadores têm apresentado um método simples para estimar a taxa de vazão de ar através da ventilação natural, o que pode ser visualizado na equação abaixo:

$$
Q=C_{V R E F} \cdot H_{0} \cdot \mu_{R E F}
$$

Onde:

$\mathrm{Q}=$ taxa de vazão de ar $\left(\mathrm{m}^{3} / \mathrm{s}\right)$;

$C_{V R E F}=$ coeficiente de ventilação;

$H_{\bullet}=$ altura da abertura da entrada de ar (m);

$\mu_{R E F}=$ velocidade referência do ar $(\mathrm{m} / \mathrm{s})$.

$C_{V R E F}$ é dependente da direção do vento e do modelo da edificação, incluindo as configurações das entradas e saídas de ar. Na literatura diferentes propostas para o valor deste coeficiente podem ser encontradas. ASHRAE (1981) propõe valores de 0,5 a 0,6, Choiniére (1991) 0,4 e Verlinde et al. (1998) 0,4 a 0,52. Uma das incertezas deste coeficiente é a forma com que os autores referem-se a velocidade de referência do ar $\left(\mu_{R E F}\right)$. Se a altura padrão da velocidade de referência do ar for conhecida, a velocidade 
do ar para a altura da entrada de ar em questão, pode ser calculada pelo perfil de velocidade do vento dado pela seguinte equação:

$$
v_{0}=\mu_{r e f} \cdot\left(\frac{h_{0}}{h_{r e f}}\right)^{n}
$$

Onde:

$v_{0}=$ velocidade do vento na abertura $(\mathrm{m} / \mathrm{s})$;

$\mu_{\text {ref }}=$ velocidade do vento de referência $(\mathrm{m} / \mathrm{s})$;

$h_{0}=$ altura atual do centro da abertura;

$h_{r e f}=$ altura de referência para medidas de ventilação;

$\mathrm{n}=$ expoente que expressa a topografia da região. Em áreas agrícolas, normalmente é utilizado $\mathrm{n}=0,1$ a 0,2 .

\section{b) Ventilação térmica}

$\mathrm{Na}$ ventilação térmica, as diferenças de temperatura provocam variações de densidade do ar no interior das edificações, que causam por efeito de tiragem ou termossifão diferenças de pressão, que se escalonam no sentido vertical. Essa diferença de pressão é função da diferença de temperatura do ar entre o interior das edificações e o exterior, do tamanho das aberturas de entrada e saída do ar pelo lanternim e, por fim, da diferença de nível entre essas aberturas. Esse efeito é também denominado de efeito chaminé e considerando uma cobertura, naturalmente ventilada, esse efeito existe independentemente da velocidade do ar externo (Abreu \& Abreu, 2005).

Se a edificação dispuser de aberturas, próximas ao piso e no telhado e se o ar do interior estiver a uma temperatura mais elevada que o ar do exterior, o ar mais quente, menos denso, tenderá a escapar pelas aberturas superiores. Ao mesmo tempo, o ar do exterior, mais frio, e por isso mais denso penetra pelas aberturas inferiores, causando fluxo constante no interior da instalação.

Vários outros fatores podem fazer variar a taxa mínima requerida para a ventilação natural térmica em instalações para animais, como produção e perda de calor pela 
construção, umidade relativa em seu interior, produção e perda de calor e de umidade pelos animais (Baêta \& Souza, 1997).

No inverno a ventilação deve ser basicamente higiênica, devendo retirar do galpão o excesso de gases, poeira e vapores produzidos, tendo então um caráter permanente. Já nos períodos mais quentes do ano, deve ser conjugada a ventilação higiênica com a térmica, numa tentativa de extrair da instalação o excesso de calor concentrado na mesma. A ventilação de verão passa a depender então das flutuações térmicas do ambiente.

Segundo Frota \& Shiffer (1995), a fórmula básica para o cálculo do fluxo de ar por efeito chaminé é:

$$
\begin{gathered}
\Phi_{C}=0,14 \cdot A \sqrt{H \cdot \Delta t_{1}} \\
\Delta t_{1}=(1-\mathrm{m}) \Delta t
\end{gathered}
$$

onde:

$\Phi_{C}=$ fluxo de ar por efeito chaminé $\left(\mathrm{m}^{3} / \mathrm{s}\right)$;

$\mathrm{A}$ = área da abertura, considerada a de entrada ou de saída $\left(\mathrm{m}^{2}\right)$;

$\mathrm{H}=$ altura da medida a partir da metade da altura da abertura de entrada de ar até a metade da abertura de saída do ar (m);

$\mathrm{m}=$ coeficiente de amortecimento da construção;

$\Delta t=$ diferença de temperatura interna e externa $\left({ }^{\circ} \mathrm{C}\right)$.

\section{c) Aberturas de ventilação}

As dimensões e a localização das aberturas, bem como a correta orientação das construções, são fatores importantes observados no controle da corrente do ar. A corrente de ar é normalmente ocasional e intermitente e pode ser manejada adequadamente por meio de aberturas dispostas convenientemente (Abreu \& Abreu, 2005).

Boon (1978) testou diferentes tipos de aberturas e configurações de ventilação em instalações para produção animal. Concluiu que na maioria das instalações estudadas, a 
velocidade do ar ao nível dos animais foi bastante afetada pela taxa de ventilação. Foram mensuradas variáveis climáticas como temperatura, umidade relativa, velocidade do vento, taxa de ventilação e movimentação do ar. Observou-se que as variações de temperatura do piso para a cobertura foram função da direção da movimentação do ar.

Jin \& Ogilvie (1992) também investigaram a direção e a velocidade do vento ao nível dos animais. Foram encontradas correlações entre a velocidade do ar em algumas regiões do piso das instalações com a configuração das entradas de ar, o que incluía tipo de abertura, dimensão e localização.

Um telhado dotado de grande inclinação motiva maior velocidade do ar sobre a cumeeira e como conseqüência, ocorre uma pressão negativa mais acentuada, sendo o ar mais rapidamente succionado para fora da dependência, o que é desejável. Uma forma de direcionar o fluxo de ar é localizar a abertura de saída de ar na cumeeira do telhado, pois, nesta região há sempre alguma pressão negativa.

Ventilação adequada é essencial para uma edificação assegurar que a qualidade do ar e condições térmicas são satisfatórias para animais e tratadores. Animais podem ocupar uma instalação por 24 horas diárias enquanto os tratadores podem permanecer 8 horas ou mais. Principalmente a velocidade do ar e a temperatura são conhecidas por afetar o conforto térmico dos animais. Vazão de ar e turbulência afetam a dispersão de gases e partículas poluentes que são nocivos a saúde e bem-estar tanto dos animais como dos tratadores. É importante compreender e quantificar os modelos de distribuição do ar e as características de turbulência das vazões do ar, tanto que pode-se distribuir ar renovado eficientemente sendo possível criar um saudável microclima ao redor de humanos e animais (Harral \& Boon, 1997).

Outro modo eficiente de reduzir a carga térmica em épocas quentes é a ventilação do ático, colchão de ar que se forma entre a cobertura e o forro (Figura 4). Essa técnica consiste em direcionar o fluxo de ar para o lanternim, por meio de aberturas feitas ao longo do beiral da construção, sendo indicada mesmo na existência de forro, nesse caso, é necessário distribuir, de forma adequada, algumas aberturas no mesmo (Baêta \& Souza, 1997). 


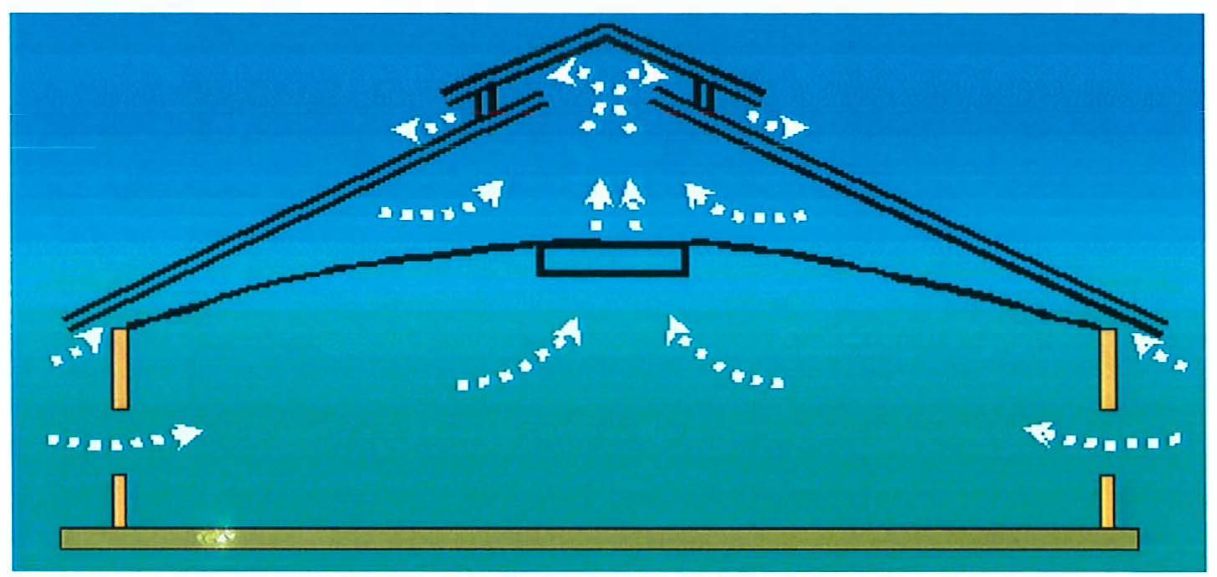

Figura 4 - Ventilação do ático. Fonte: Abreu \& Abreu (2005)

Abrindo-se as cortinas da instalação pode passar rapidamente um grande volume de ar exterior que se mistura com as condições do ar interno tendendo a se igualar com as condições exteriores. Portanto, a ventilação por abertura de cortinas é ideal quando a temperatura externa está próxima das exigências dos animais. A melhor ocasião para se usar a ventilação por meio de cortinas é quando a temperatura externa é igual ou inferior à da instalação. Quanto maior for esse gradiente de temperatura mais eficiente será a perda de calor por convecção.

Nas edificações com ventilação natural, aberturas laterais podem ser controladas automaticamente ou manualmente, por exemplo, por cortinas laterais. Em condições de excesso de ventos, o manejo de cortinas pode resultar em sérios problemas de deficiência de ventilação na área ocupada pelos animais. Para minimizar o problema de excesso de ventos, as aberturas são freqüentemente ajustadas para um mínimo, resultando em uma baixa de vazão de ar de entrada e conseqüentemente pior qualidade de ar no interior da edificação (Morsing et al., 2000).

O ambiente térmico dentro do escamoteador é resultado do calor gerado em seu interior e da convecção natural que ocorre em seu entorno. As trocas de ar diferem de outros tipos de instalações ventiladas naturalmente, pelos grandes gradientes de temperatura que ocorrem dentro do escamoteador. O tamanho e o tipo de abertura também podem influenciar no gradiente de temperatura e na movimentação de ar (Zhang et al., 2001). 
Métodos convencionais para projetar um sistema de ventilação natural são normalmente baseados na teoria da mistura perfeita de ar em espaços com distribuição uniforme da temperatura. Isto é válido quando a variação da temperatura vertical sobre uma abertura é muito menor do que as diferenças de temperaturas na horizontal. Entretanto, a convecção natural devido às trocas de calor aumenta a variação da temperatura nos escamoteadores e a variação da temperatura vertical pode ser maior que as variações na horizontal. Os escamoteadores dentro de instalações abertas é um caso típico de grandes gradientes de temperatura (Zhang et al.,2001).

Informações básicas sobre a movimentação do ar, assim como, o mapeamento de perfis da temperatura no interior de escamoteadores e das salas de maternidade, podem ser utilizados para melhorar o projeto dos sistemas de aquecimento, assegurando o bem-estar e a produção animal.

\subsection{Ventilação artificial, mecânica ou forçada}

A ventilação artificial é produzida por equipamentos especiais como exaustores e ventiladores. É utilizada sempre que as condições naturais de ventilação não proporcionam adequada movimentação do ar ou abaixamento de temperatura. Tem a vantagem de permitir filtragem, distribuição uniforme e suficiente do ar no aviário e ser independente das condições atmosféricas. Permite fácil controle da taxa de ventilação através do dimensionamento dos ventiladores, das entradas e saídas de ar. Porém o sistema por ventilação artificial não é adequado para salas de maternidade, pois a ventilação oferecida às porcas será prejudicial aos leitões, que além de sentirem muito frio, não apreciam correntes de vento.

Existem duas formas de se promover artificialmente a movimentação do ar:

- sistema de pressão negativa ou exaustão;

- sistema de pressão positiva ou pressurização.

Tanto no sistema de ventilação, por pressão negativa quanto por pressão positiva, atenção deve ser dada à pressão que está relacionada diretamente com a vazão e não com 
a velocidade do ar. Dessa forma, é importante o conhecimento de quanto de ar deve ser renovado por unidade de tempo. É comum encontrar em uma edificação zonas de pressão de baixa movimentação de ar, seja por pressão negativa ou positiva. Um dos fatores mais freqüentes para essa ocorrência é o mau dimensionamento e posicionamento dos equipamentos de ventilação.

Tolon (2002), avaliou a possibilidade de usar resfriamento adiabático e ventilação forçada na maternidade para suínos. Concluiu que o uso do sistema de resfriamento adiabático sobre as porcas diminuiu a temperatura de bulbo seco, entretanto não atingiu o valor de temperatura de termoneutralidade sugerido pela literatura. Diminuiu, também, a frequência respiratória, porém sem causar diferença fisiológica. Salientou-se que esse sistema deve ser usado de forma controlada, já que contribui para o aumento da umidade relativa do ar no local onde foi utilizado. O parâmetro de produtividade, ganho de peso médio e peso médio ao desmame não foram influenciados estatisticamente pelos dois sistemas, mas foi observada uma tendência de aumento no ganho de peso dos leitões cujas mães estavam submetidas a ventilação com resfriamento adiabático.

\subsection{Respostas Fisiológicas ao estresse térmico}

\subsubsection{Temperatura de pele}

A temperatura de pele depende da temperatura do ar (Terui et al., 1984; Chikamune, 1986; Gerken et al., 1998). Esta pode, entretanto, ser significativamente influenciada por outros fatores microclimáticos.

A medida da temperatura da pele foi adotada, por indicar mais rapidamente, e de modo prático, se os animais encontram-se fora da zona de conforto em uma amplitude que prejudique a produtividade dos mesmos. Sabe-se que a temperatura da pele sofre alterações mais rápidas, em razão da dissipação de calor, por convecção do fluxo 
sangüíneo, do interior do núcleo corporal para a periferia, o que permite decisões imediatas que impeçam queda no desempenho dos animais.

Carvalho et al. (2004), realizaram um experimento com o objetivo de avaliar os efeitos da nebulização e ventilação forçada sobre o desempenho e a temperatura de pele de suínos na fase de terminação. A temperatura da pele dos animais foi medida superficialmente, sem contato, utilizando-se termômetro digital, direcionado transversalmente aos locais da nuca, pernil dianteiro esquerdo e pernil traseiro esquerdo. Os resultados não demonstraram diferenças significativas entre os tratamentos utilizados para as variáveis ganho de peso médio diário, consumo de ração médio diário e conversão alimentar. Entretanto, a nebulização de água associada à ventilação forçada apresentou menores valores de temperatura da pele, indicando melhor conforto aos animais. Esse trabalho comprova que mudanças no ambiente térmico dos animais alteram suas temperaturas superficiais corporais.

Mitchell (1985), estudando o efeito da ventilação em aves de corte adultas, observou que a $20^{\circ} \mathrm{C}$ o aumento da velocidade do vento de 0,3 para $1,05 \mathrm{~m} / \mathrm{s}$, não promoveu nenhuma redução na temperatura de pele dos frangos. No entanto, aves submetidas a temperatura de $30^{\circ} \mathrm{C}$ tiveram uma redução em sua temperatura de pele de $0,6^{\circ} \mathrm{C}$ quando a velocidade do vento passou de 0,3 para $1,05 \mathrm{~m} / \mathrm{s}$, mostrando-se como uma forma efetiva de resfriar a ave, reduzindo a demanda por perdas evaporativas de calor, além de auxiliar na manutenção de sua temperatura corporal. Neste trabalho não houve menção à umidade relativa a que as aves estavam sendo submetidas.

Knízková et al. (2002), realizaram dois experimentos com 12 vacas em lactação para cada. $\mathrm{O}$ experimento foi realizado em apenas quatro dias de coleta de dados, sendo dois dias de verão e dois dias de outono. Os autores coletaram temperaturas superficiais corporais dos animais como medida de bem-estar e conforto térmico em função de mudanças no microclima da edificação através do manejo de cortinas (aberta $v s$ fechada), ou seja, modificando a taxa de ventilação natural fornecida aos animais. Os autores concluíram que quando a temperatura do ar estava entre a zona de termoneutralidade das vacas, estas respondiam ao excessivo aumento na velocidade do ar com uma redução em suas perdas de calor, que eram manifestadas por uma significante resposta vascular e por 
variações em suas temperaturas de pele. Por outro lado, uma subseqüente diminuição na velocidade do ar, fez as vacas aumentarem suas perdas de calor que foram manifestadas também por variações em suas temperaturas de pele. Esses resultados concordam com Burkjav (1986) e Oslon (1984), que afirmam que mudanças nas condições térmicas desencadeiam respostas vasculares na pele dos animais que resultam no aumento ou diminuição de suas perdas de calor. 


\section{MATERIAL E MÉTODOS}

O experimento foi realizado na Granja Querência, propriedade cuja principal atividade é a produção industrial de suínos, localizada no município de Elias Fausto, SP, apresentando latitude de $22^{\circ} 36^{\prime} \mathrm{S}$, longitude de $47^{\circ} 36 \mathrm{~W}$ ' e altitude de $532 \mathrm{~m}$. O clima da região é caracterizado como mesotérmico Cwa (tropical de altitude), com temperatura do mês mais frio entre -3 e $18^{\circ} \mathrm{C}$, com inverno seco e temperatura do mês mais quente maior que $22^{\circ} \mathrm{C}$.

A pesquisa foi desenvolvida na sala da maternidade desta Granja no período das 9:00 às 14:00 horas dos dias 14, 15, 29 e 30 de abril de 2005. Estudou-se e mensurou-se as variações, induzidas por diferentes aberturas de entrada de ar, nas seguintes variáveis: umidade relativa, temperatura de bulbo seco e velocidade do ar no interior do galpão; temperatura de bulbo seco, umidade relativa e temperatura superficial dos pisos dos escamoteadores equipados com diferentes fontes de aquecimento: lâmpadas incandescentes e pisos térmicos; e temperatura de pele das matrizes e leitões.

\subsection{Características das instalações estudadas}

Os abrigos escamoteadores possuíam as dimensões de 1,50 m de comprimento, $0,55 \mathrm{~m}$ de largura e $0,65 \mathrm{~m}$ de altura, totalizando uma área de $0,83 \mathrm{~m}^{2} \mathrm{e}$ um volume de $0,54 \mathrm{~m}^{3}$.

A sala da maternidade possuía as dimensões de 30,0 m de comprimento, $8,80 \mathrm{~m}$ de largura e pé direito de $3,0 \mathrm{~m}$. A cobertura era constituída com telhas cerâmicas do tipo francesa, com forro de placas de poliestireno. Ao longo da sala, a instalação apresentava oito janelas em cada lateral, com comprimento de 1,50 m e altura de 1,30 m, 
totalizando uma área de abertura de $31,2 \mathrm{~m}^{2}$. As duas laterais da instalação apresentavam cortinas plásticas de cor amarela que abrangiam toda a área de abertura das janelas.

$\mathrm{Na}$ sala foram alojadas 34 matrizes, em 34 gaiolas. As gaiolas possuíam dimensões de 2,40 $\mathrm{m}$ de comprimento, 0,60 $\mathrm{m}$ de largura e 1,10 $\mathrm{m}$ de altura, totalizando 1,44 $\mathrm{m}^{2}$ de área, localizadas no centro de cada baia. As baias possuíam dimensões de 1,7 $\mathrm{m}$ de largura, 3,10 $\mathrm{m}$ de comprimento e 0,65 $\mathrm{m}$ de altura, totalizando uma área de 5,27 $\mathrm{m}^{2}$. A área resultante da diferença da área ocupada pela gaiola (matriz) pela área total da baia é de $3,83 \mathrm{~m}^{2}$, sendo ocupada pelos leitões quando estes não se encontram no interior dos escamoteadores. A Figura 5 mostra o esquema da localização das seis baias utilizadas no estudo.

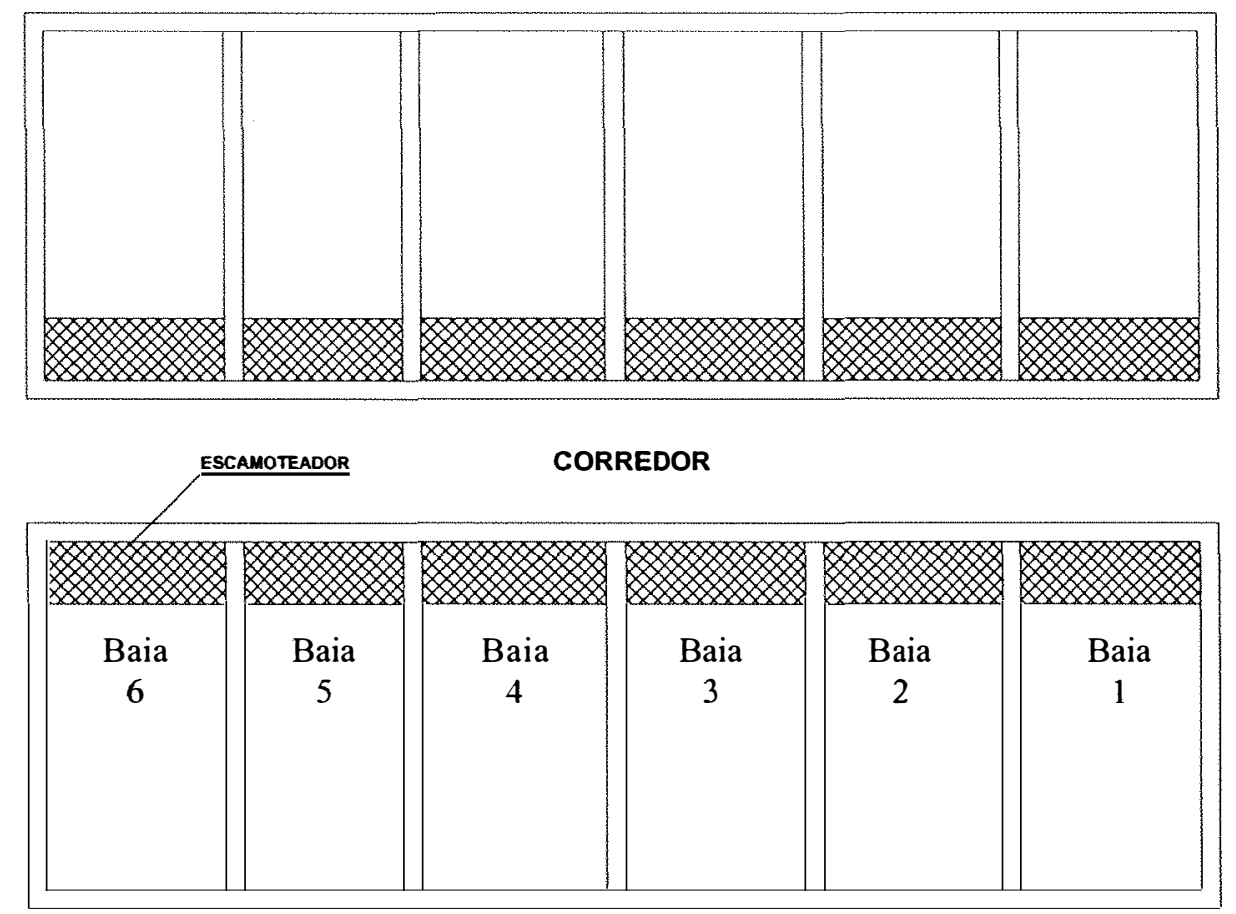

Figura 5. Esquema da localização das baias avaliadas no interior da sala de maternidade

\subsection{Animais do estudo}

O estudo foi realizado com animais híbridos Threecross (Landrace $\mathrm{x}$ Large White $\mathrm{x}$ Duroc). Os leitões que fizeram parte do estudo eram provenientes de matrizes de 
mesma ordem de parto, selecionadas com o objetivo de eliminar fatores de interferência, habilidade materna, número de leitões/leitegada. Cada baia possuía 10 leitões que, após os partos, foram remanejados por critério de peso e número de animais/leitegada.

\subsection{Condições de aberturas de entrada de ar avaliadas}

Durante o período experimental diurno, foram estudadas três condições distintas de aberturas de entrada de ar:

- Cortina lateral dos ventos dominantes totalmente aberta (Figura 6);

- Cortina lateral dos ventos dominantes semi-aberta (Figura 7);

- Cortina lateral do vento dominante totalmente fechada (Figura 8).

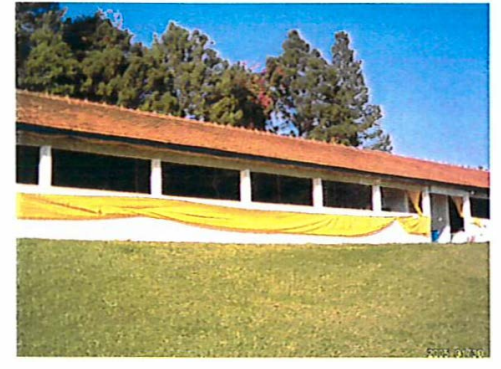

Figura 6 - Abertura lateral totalmente aberta (A)

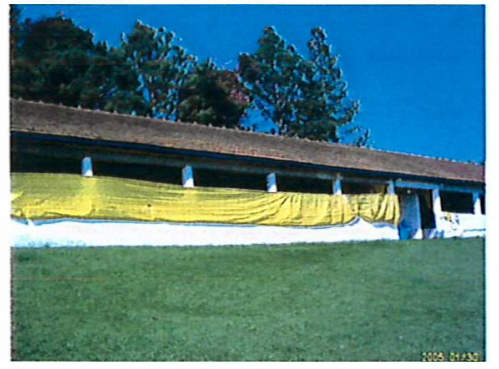

Figura 7 - Abertura lateral semi-aberta (AF)

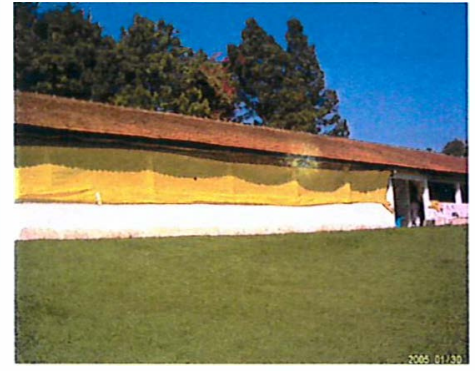

Figura 8 - Abertura lateral totalmente fechada $(F)$

A cortina lateral do lado oposto aos ventos dominantes permaneceu totalmente aberta no período diurno. Já no período noturno, ambas cortinas permaneceram totalmente fechadas. 


\subsection{Fontes de aquecimento estudadas}

Para as diferentes condições de abertura de entrada de ar, foram avaliadas as respostas térmicas de dois tipos distintos de fontes de calor no interior dos escamoteadores:

- Lâmpadas incandescentes;

- Pisos Térmicos.

\subsubsection{Lâmpadas Incandescentes}

Dos seis escamoteadores estudados, três foram equipados por lâmpadas incandescentes de 200 W. Utilizou-se uma lâmpada por escamoteador, cada qual protegida por uma grade metálica e instalada na parede lateral oposta a abertura de acesso dos leitões, a uma altura de 0,50 m do piso, conforme pode ser visto na Figura 9.

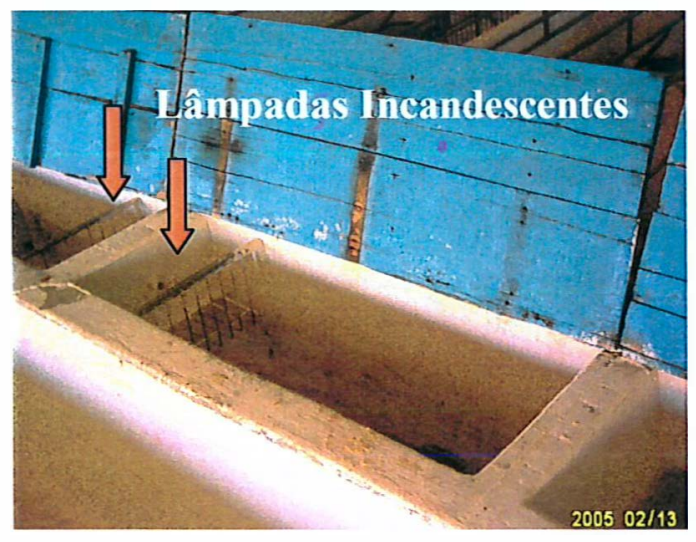

Figura 9 - Localização das lâmpadas incandescentes no interior dos escamoteadores

\subsubsection{Pisos térmicos}

Os três escamoteadores restantes foram equipados por pisos térmicos da marca Technisul®, construídos com dimensões próprias para os escamoteadores da Granja. Os 
pisos térmicos são constituídos de cabo de aço inox com liga níquel-cromo revestido com duas camadas de proteção de $0,8 \mathrm{~mm}$ de espessura cada; sendo a camada interna de polietileno reticulado (XLPE) e a externa de PVC. O processo de montagem dos pisos pode ser observado nas Figuras 10, 11, 12, e 13.

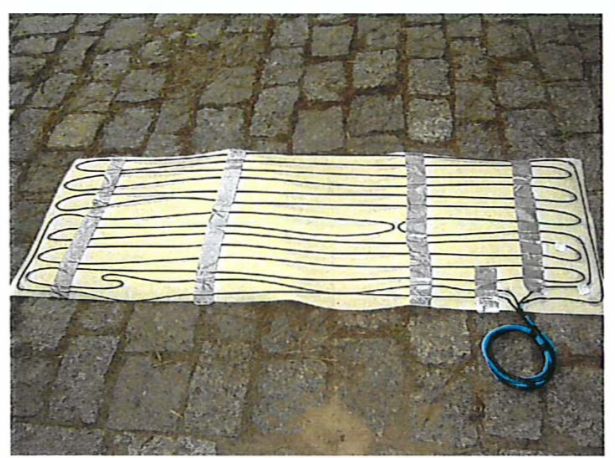

Figura 10 - Piso pronto para ser coberto por argamassa

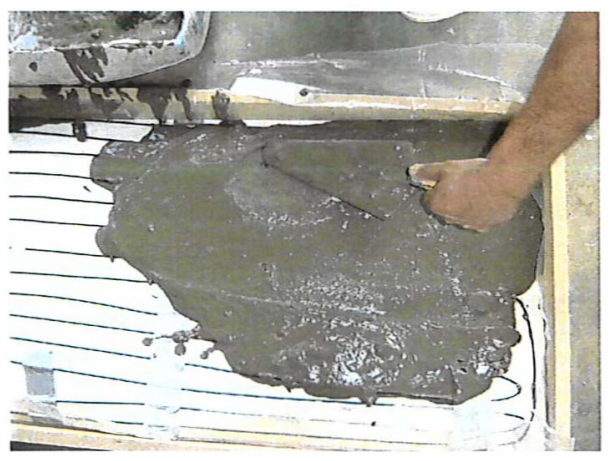

Figura 12 - Montagem do piso térmico

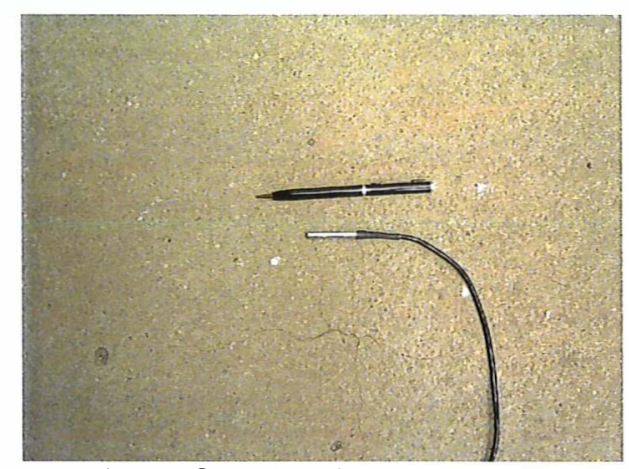

Figura 11 - Sensor de temperatura a ser embutido no piso

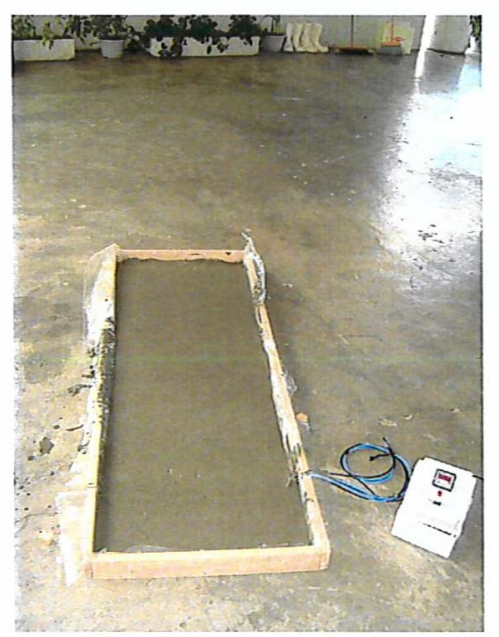

Figura 13 - Vista de um molde de piso térmico com o termostato 


\subsection{Coleta de dados}

\subsubsection{Variáveis climáticas mensuradas no interior da sala de maternidade}

a) Temperatura de bulbo seco e umidade relativa: ambas variáveis foram coletadas e armazenadas por um datalogger da marca Hobo com amplitude de -20 a $70^{\circ} \mathrm{C}$ e precisão de 0,7 a $21^{\circ} \mathrm{C}$ para a temperatura e amplitude de 25 a $95 \%$ com precisão de $5 \%$ para a umidade relativa. Os dados foram coletados a cada 15 minutos durante quatro dias não consecutivos no período de outono de 2005, segundo metodologia proposta por Knízková et al. (2002). A sala de maternidade foi dividida em oito quadrantes, sendo instalado um datalogger no centro de cada quadrante (ponto), a três metros do piso, como pode ser observado nas Figura 14 e 15.

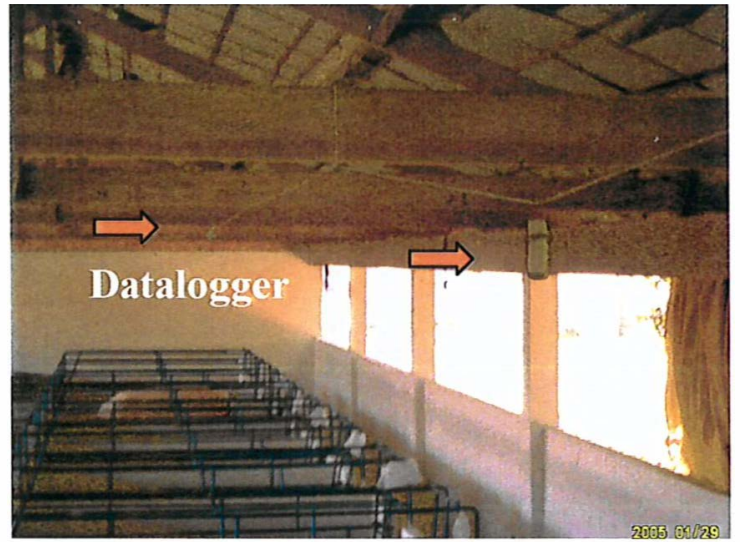

Figura 14 - Localização dos dataloggers no interior da sala de maternidade

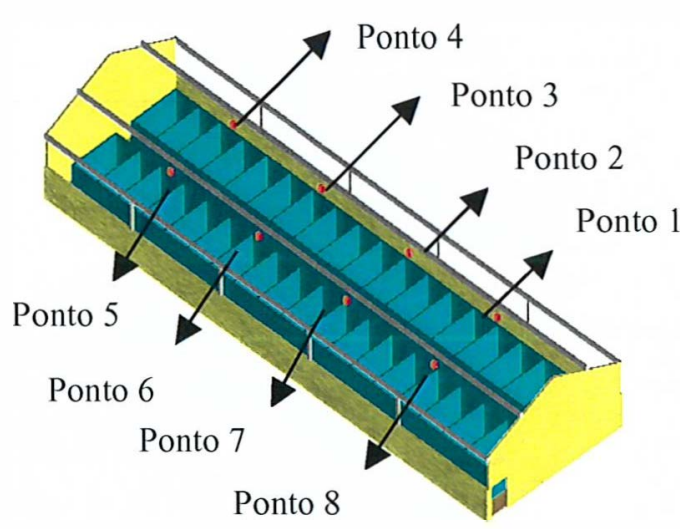

Figura 15 - Representação dos pontos de coleta onde foram instalados os dataloggers

b) Velocidade do Vento: a velocidade do vento foi coletada através de um termoanemômetro de fio quente e digital da marca Alnor (Figura 16). Os dados foram coletados em três alturas no centro dos quadrantes: um metro, dois metros e três metros do piso, no período das 9:00 às 11:00 horas, nos dias 29 e 30 de abril de 2005. Coletaram-se quatro 
repetições de velocidade do vento para cada uma das três diferentes aberturas de entrada de ar, das 9:00 às 14:00h em intervalos de 45 minutos para cada condição de abertura.

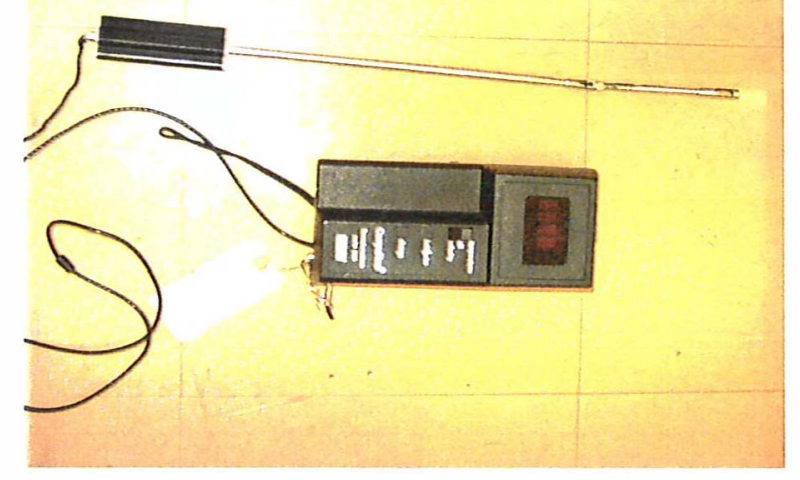

Figura 16 - Termo-anemômetro digital de fio quente

\subsubsection{Variáveis mensuradas no interior dos escamoteadores}

a) Temperatura de bulbo seco e umidade relativa: ambas variáveis foram coletadas e armazenadas também por um datalogger da marca Hobo, instalado na parte superior de cada um dos seis escamoteadores, como pode ser observado na Figura 17. Os dados foram coletados a cada 2 minutos durante os quatro dias de estudo.

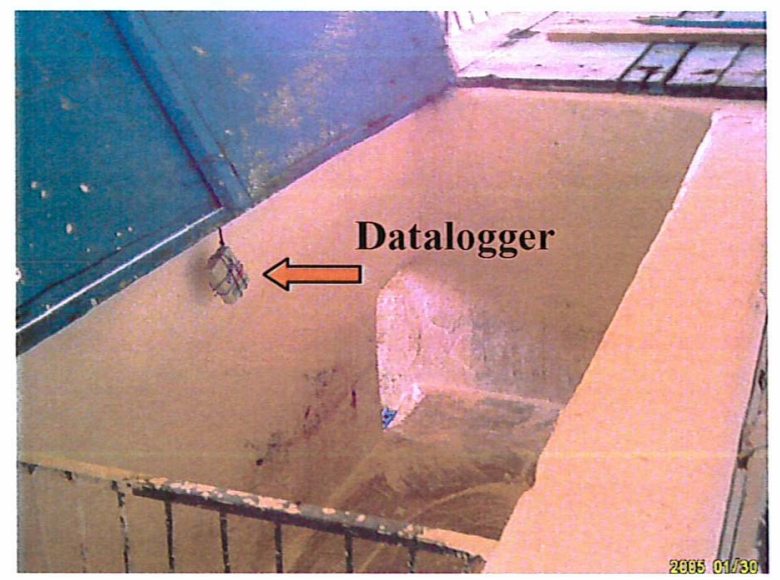

Figura 17 - Localização do datalogger no interior dos escamoteadores

b) Velocidade do Vento: a velocidade do vento foi coletada utilizando o mesmo termo-anemômetro de fio quente e digital. A coleta de dados foi realizada na abertura de 
acesso aos leitões, simultaneamente com a coleta da temperatura de superfície dos pisos dos escamoteadores. Os dados foram coletados das 9:00 às 14:00h em intervalos de 45 minutos para cada condição de abertura.

c) Temperatura da superficie do piso: a temperatura dos pisos dos escamoteadores foi coletada utilizando-se um Termômetro Infravermelho da marca Omega (Figura 18), com amplitude de $-18^{\circ} \mathrm{C}$ a $400^{\circ} \mathrm{C}$ e precisão de $2{ }^{\circ} \mathrm{C}$, sob temperaturas de 0 a $40^{\circ} \mathrm{C}$. A emissividade calibrada para a coleta de dados foi de 0,88 , referente ao concreto. Para a coleta de dados, os pisos foram divididos em 18 quadrantes, sendo coletados um total de 36 pontos. O esquema dos pontos de coleta de dados pode ser observado na Figura 19.

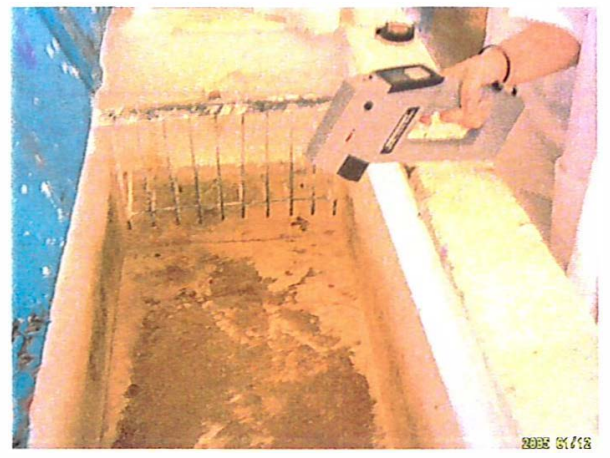

Figura 18 - Coleta das temperaturas superficiais com o Termômetro de Infravermelho

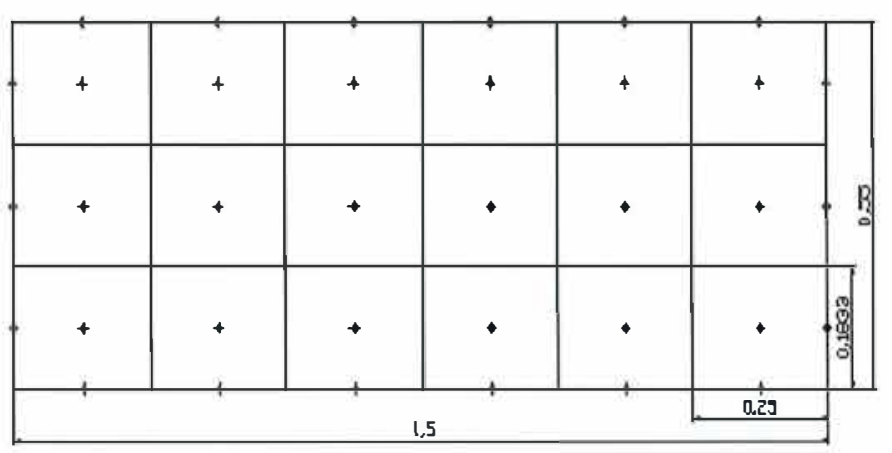

Figura 19 - Representação dos pontos de coleta da temperatura superficial dos pisos

\subsubsection{Variáveis climáticas externas à sala de maternidade}

a) Temperatura de bulbo seco e umidade relativa: ambas variáveis foram coletadas e armazenadas por um dos dataloggers da marca Hobo já mencionado. Os 
dados foram coletados a cada 15 minutos durante o período do estudo. A localização do datalogger pode ser observada na Figura 20.

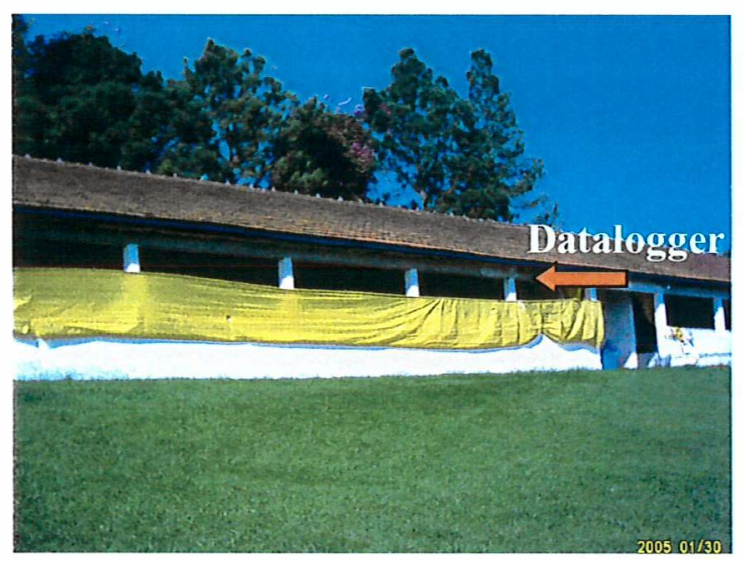

Figura 20 - Posicionamento do datalogger para coleta de dados externos

b) Velocidade do Vento: a velocidade do vento foi coletada através do termoanemômetro, já citado anteriormente. Os dados foram coletados simultaneamente com a coleta dos dados de velocidade dos ventos no interior da sala de maternidade.

\subsubsection{Variável fisiológica dos animais}

a) Temperatura de pele dos animais: para a coleta da temperatura de pele dos leitões e matrizes também se utilizou o Termômetro Infravermelho da marca Omega, porém calibrado com a emissividade usual para animais, 0,97. Nas matrizes, os pontos de coleta foram: pernil e nuca, conforme metodologia proposta por Carvalho et al. (2004). Nos leitões a temperatura de superfície foi coletada em um único ponto, no dorso dos animais. Foram realizadas quatro repetições de coleta de dados, sendo os dados coletados das 9:00 às 14:00h em intervalos de 45 minutos para cada condição de abertura estudada. 


\subsection{Análise de dados}

Todas as análises estatísticas foram realizadas utilizando-se os softwares Statistical Analysis System (SAS, 2002) e Minitab (12.1).

\subsubsection{Análise dos dados da velocidade do vento no interior da sala de maternidade}

Para a análise dos dados de velocidade do vento foi utilizado um delineamento com quatro fatores e uma covariável. Dos quatro fatores três são principais (altura de coleta, pontos de coleta e aberturas de entrada de ar) e um é fator de blocagem (dia de coleta dos dados). A covariável foi a velocidade externa do vento e a variável resposta, a velocidade interna do vento.

O fator altura de coleta possui três níveis (1,0, 2,0 e 3,0 metros do piso), o fator pontos de coleta, oito níveis, que correspondem aos pontos de coleta dos dados de acordo com a Figura 15 e o fator aberturas de entrada de ar (manejos da cortina), possui três níveis (totalmente aberta, semi-aberta e totalmente fechada). Houve três repetições para cada nível combinado entre os fatores apresentados.

Através da Análise de Covariância foi possível avaliar os efeitos dos níveis dos fatores e da covariável sobre a ventilação interna, demonstrando assim, como esta variou no interior da sala de maternidade.

\subsubsection{Análise dos dados de temperatura superficial dos pisos dos escamoteadores}

Para a análise dos dados de temperatura superficial dos pisos foi utilizado um delineamento com quatro fatores (tipo de aquecimento, escamoteador (baia), manejos da cortina e dia de coleta) e três covariáveis (temperatura, umidade relativa e velocidade do vento no interior do escamoteador). A variável resposta foi a temperatura superficial dos pisos.

O fator tipo de aquecimento possui dois níveis (lâmpada incandescente e piso térmico), o fator escamoteador possui seis níveis que correspondem as seis baias 
utilizadas no estudo conforme Figura 5, o fator manejo da cortina possui três níveis (totalmente aberta, semi-aberta e totalmente fechada) e o fator dia de coleta, quatro níveis.

Através da Análise de Covariância foi possível avaliar os efeitos dos níveis dos fatores e das covariáveis sobre a temperatura superficial dos pisos.

\subsubsection{Análise dos dados de temperatura no interior da sala}

Para a análise dos dados da temperatura de bulbo seco do interior da sala foi utilizado um delineamento com três fatores principais (dia de coleta, pontos de coleta e manejos da cortina) e duas covariáveis (velocidade externa do vento e umidade relativa). $\mathrm{O}$ fator dia de coleta possui quatro níveis, o fator pontos de coleta, oito níveis e o fator manejo da cortina possui três níveis (totalmente aberta, semi-aberta e totalmente fechada). A variável resposta foi a temperatura interna da sala de maternidade.

Através da Análise de Covariância foi possível avaliar os efeitos dos níveis dos fatores e das covariáveis sobre a temperatura no interior da sala de maternidade.

\subsubsection{Análise dos dados de umidade relativa do interior da sala}

Para a análise dos dados da umidade relativa foi utilizado um delineamento com três fatores principais (dia de coleta, pontos de coleta e manejos da cortina) e duas covariáveis (velocidade externa do vento e temperatura interna). $\mathrm{O}$ fator dia de coleta possui quatro níveis, o fator pontos de coleta, oito níveis e o fator manejo da cortina possui três níveis (totalmente aberta, semi-aberta e totalmente fechada). A variável resposta foi a umidade relativa no interior da sala de maternidade.

Através da Análise de Covariância foi possível avaliar os efeitos dos níveis dos fatores e das covariáveis sobre a umidade no interior da sala de maternidade. 


\subsubsection{Análise dos dados da temperatura de pele das matrizes e leitões}

Para a análise dos dados da temperatura de pele dos animais foi utilizado um delineamento com dois fatores principais (manejos da cortina e baias) e quatro covariáveis (velocidade externa do vento, velocidade no interior da baia, umidade relativa e temperatura externas ao galpão). $\mathrm{O}$ fator manejo da cortina possui três níveis (totalmente aberta, semi-aberta e totalmente fechada) e as baias, seis níveis que correspondem as seis baias utilizadas no estudo. A variável resposta foi a temperatura de pele das matrizes e dos leitões. Houve quatro repetições para cada nível combinado entre os fatores apresentados.

Através da Análise de Covariância foi possível avaliar os efeitos dos níveis dos fatores e das covariáveis sobre a temperatura de pele dos animais. 


\section{RESUlTADOS E DISCUSSÃO}

\subsection{Análise dos dados da velocidade do vento no interior da sala de maternidade}

\subsubsection{Análise descritiva}

A análise descritiva tem por objetivo documentar resumidamente as informações obtidas dos dados coletados, facilitando a formalização das hipóteses a serem construídas com o auxílio de uma futura análise exploratória. Nas Tabelas 4, 5, 6 e 7, apresenta-se os resultados da análise descritiva para o fator dia de coleta, altura de coleta, pontos de coleta e manejo da cortina, respectivamente.

Tabela 4. Resultado da análise descritiva dos dias de coleta para a velocidade do vento no interior da sala de maternidade

\begin{tabular}{lccccccccc}
\hline Variável & Data & $\mathbf{N}$ & \multicolumn{1}{c}{ Média } & Mediana & Desv. Padrão & Min. Máx. & Q1 & Q3 \\
\hline Velocidade & $29 / a b r$ & 287 & 0,12698 & 0,13 & 0,06491 & 0 & 0,3 & 0,1 & 0,16 \\
do vento (m/s) & $30 / a b r$ & 284 & 0,1525 & 0,15 & 0,04818 & 0 & 0,29 & 0,12 & 0,18 \\
\hline
\end{tabular}

Tabela 5. Resultado da análise das alturas de coleta para a velocidade do vento no interior da sala de maternidade

\begin{tabular}{lccccccccc}
\hline Variável & Pontos & $\mathbf{N}$ & Média & \multicolumn{1}{c}{ Mediana } & Desv.Padrão & Min. & Max. & Q1 & Q3 \\
\hline \multirow{3}{*}{ Velocidade } & 1 & 191 & 0,12649 & 0,13 & 0,05696 & 0 & 0,28 & 0,1 & 0,16 \\
do vento $(\mathrm{m} / \mathrm{s})$ & 2 & 188 & 0,14816 & 0,15 & 0,06032 & 0 & 0,3 & 0,12 & 0,19 \\
\hline
\end{tabular}


Tabela 6. Resultado da análise dos pontos de coleta para a velocidade do vento no interior da sala de maternidade

\begin{tabular}{lccccccccc}
\hline Variável & Pontos & $\mathbf{N}$ & \multicolumn{2}{c}{ Média } & Mediana Desv.Padrão & Min. & Max. & Q1 & Q3 \\
\hline & 1 & 71 & 0,1569 & 0,15 & 0,05087 & 0 & 0,3 & 0,12 & 0,19 \\
& 2 & 71 & 0,14197 & 0,14 & 0,05285 & 0 & 0,28 & 0,12 & 0,17 \\
& 3 & 71 & 0,12344 & 0,13 & 0,05788 & 0 & 0,25 & 0,09 & 0,16 \\
Velocidade & 4 & 71 & 0,14042 & 0,14 & 0,06156 & 0 & 0,28 & 0,11 & 0,18 \\
do vento & 5 & 71 & 0,12493 & 0,13 & 0,06380 & 0 & 0,3 & 0,1 & 0,16 \\
$(\mathrm{~m} / \mathrm{s})$ & 6 & 72 & 0,14139 & 0,15 & 0,06372 & 0 & 0,3 & 0,1 & 0,18 \\
& 7 & 72 & 0,14181 & 0,14 & 0,05047 & 0 & 0,28 & 0,12 & 0,16 \\
& 8 & 72 & 0,14639 & 0,15 & 0,06110 & 0 & 0,25 & 0,12 & 0,19 \\
\hline
\end{tabular}

Tabela 7. Resultado da análise dos manejos da cortina para a velocidade do vento no interior da sala de maternidade

\begin{tabular}{lccccccccc}
\hline Variável & Manejo & N & \multicolumn{2}{c}{ Média } & Mediana Desv.Padrão & Min. & Max. Q1 & Q3 \\
\hline & A & 187 & 0,16852 & 0,16 & 0,0531 & 0,014 & 0,3 & 0,12 & 0,2 \\
Velocidade & AF & 192 & 0,15839 & 0,15 & 0,03922 & 0 & 0,29 & 0,13 & 0,18 \\
do vento (m/s) & F & 192 & 0,09286 & 0,1 & 0,05081 & 0 & 0,25 & 0,07 & 0,13 \\
\hline
\end{tabular}

\subsection{Análise Exploratória}

A análise exploratória é a avaliação preliminar dos dados, levantando e formalizando previamente as hipóteses que serão testadas na análise confirmatória (Análise de Covariância).

Nesse estudo, basicamente, a análise exploratória se estabeleceu através da análise dos gráficos (boxplots). O boxplot é uma figura que representa sumariamente a distribuição dos dados. A caixa central é delimitada pelos quartis - o primeiro quartil está no limite inferior e o terceiro quartil, no limite superior - a linha central do interior da caixa representa a mediana dos dados (segundo quartil). Dessa forma, a caixa por 
completo representa a totalidade de $50 \%$ dos dados. As linhas verticais revelam os limites que são funções dos quartis. Valores além desses limites estabelecidos são considerados outliers (pontos discrepantes), simbolizados pelo asterisco.

De maneira geral a análise comparativa dos boxsplots se dá através de suas respectivas disposições (posicionamento e forma). Quanto ao posicionamento (nivelamento), pode-se concluir sobre a tendência de haver diferença entre as magnitudes dos dados frente as condições avaliáveis. Quanto à forma, pode-se avaliar individualmente as dispersões dos dados estudados.

Nas Figuras 21, 22, 23 e 24, pode-se visualizar o gráfico boxplot para a velocidade do vento no interior da sala perante os diferentes dias, alturas e pontos de coleta e manejos da cortina, respectivamente.

Através da Figura 21, observa-se a presença de outliers para ambos os dias estudados. Observa-se, também, um nivelamento dos dados levemente diferenciado e dispersões bem similares entre os boxplots.

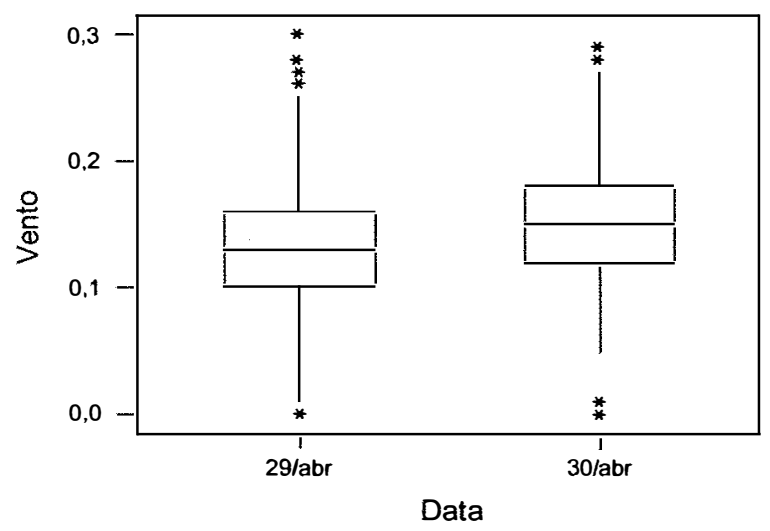

Figura 21 - Gráfico boxplot comparativo para a velocidade do vento $(\mathrm{m} / \mathrm{s})$ perante os diferentes dias de coleta

Através da Figura 22, observa-se a presença de outliers para ambas as alturas estudadas. Os nivelamentos são diferentes o que sugere para a altura de $1 \mathrm{~m}$ uma 
tendência de haver menor velocidade de vento, o que será posteriormente confirmado na análise exploratória. Já as dispersões entre os boxplots são bem similares.

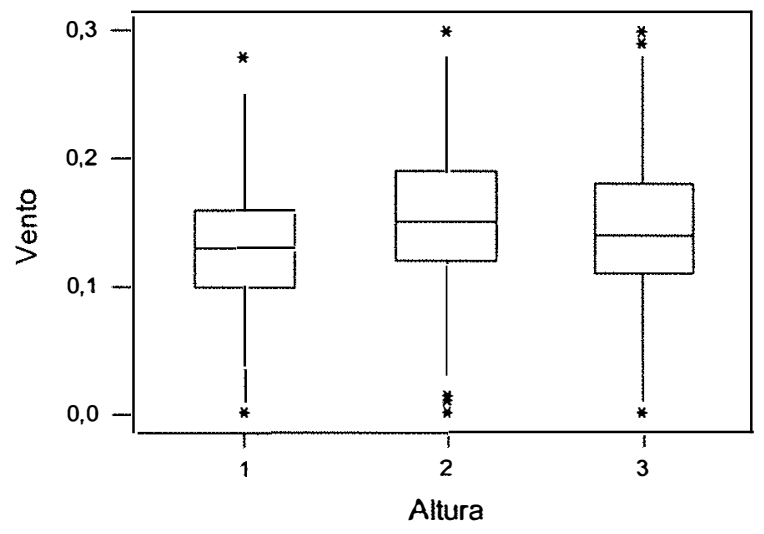

Figura 22 - Gráfico boxplot comparativo para a velocidade do vento $(\mathrm{m} / \mathrm{s})$ perante as diferentes alturas $(\mathrm{m})$

Através da Figura 23 observa-se a presença de outliers para os pontos de coleta estudados. Os nivelamentos são diferentes o que sugere uma diferenciação da magnitude da velocidade do vento para as diferentes localizações. As dispersões entre os boxplots apresentam-se ligeiramente diferentes.

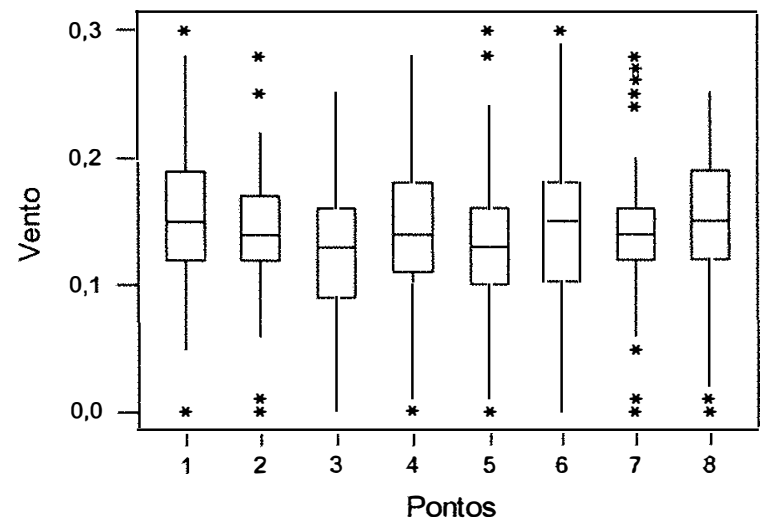

Figura 23 - Gráfico boxplot comparativo para a velocidade do vento $(\mathrm{m} / \mathrm{s})$ perante os diferentes pontos de coleta 


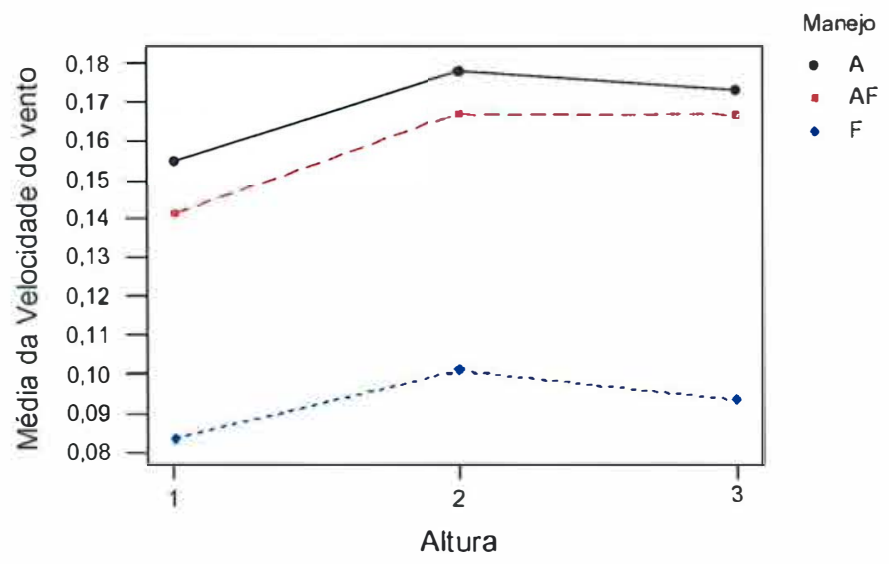

Figura 25 - Interação entre os fatores manejo e altura (m) para as médias de velocidade do vento $(\mathrm{m} / \mathrm{s})$

\subsection{Análise confirmatória}

A análise confirmatória tem o objetivo de averiguar e confirmar hipóteses levantadas sob o delineamento experimental, bem como os levantamentos feitos nas análises exploratórias. Através da Análise de Covariância avaliou-se a influência dos fatores principais sobre a variável resposta (velocidade do vento), durante os dias de coleta, considerando a ventilação externa.

Como pode-se observar na Tabela 8 , a covariável vento externo, mostrou-se significativa $(p=0,007)$ para explicar a variação da velocidade do vento interno. Os dias $(p=0,001)$, altura $(p=0,000)$ e pontos de coleta $(p=0,000)$ e os manejos da cortina $(p$ $=0,000)$, também se mostraram fontes significativas de variação na velocidade do vento interno.

De acordo com os valores p presentes na Tabela 8, ao nível de significância de $5 \%$, não houve qualquer interação entre os fatores principais. O Quadrado Médio do Erro (estimativa da variância combinada do modelo), assumiu o valor de 0,982842 .

Sabendo-se da existência de influências significativas dos fatores sobre a variável resposta e da não interação entre os fatores, cabe então, realizar o teste de 
Através da Figura 24 observa-se a presença de outliers para os diferentes manejos da cortina estudados. Os nivelamentos são diferentes o que demonstra uma diferenciação da magnitude da velocidade do vento para os diferentes manejos da cortina. Observa-se a tendência do manejo da cortina $(F)$ apresentar menor velocidade do vento em comparação com os demais. As dispersões entre eles apresentam-se ligeiramente diferentes.

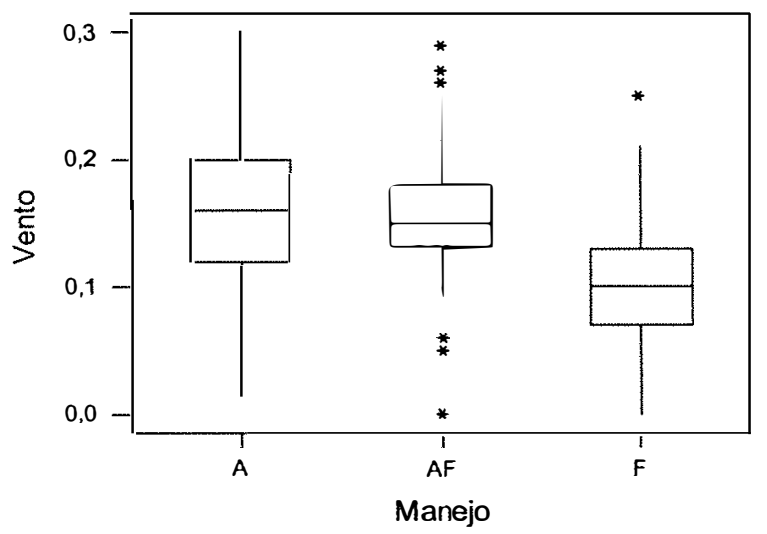

Figura 24 - Gráfico boxplot comparativo para a velocidade do vento $(\mathrm{m} / \mathrm{s})$ perante os diferentes manejos da cortina: (A) totalmente aberta, (AF) semi-aberta e (F) totalmente fechada

Através da Figura 25 observa-se um perfil de paralelismo, ou seja, de forma geral, observa-se que as linhas formadas pelos diferentes manejos da cortina são similares, porém niveladas de formas diferentes. Essa característica é padrão para o caso de não haver interação entre fatores manejo e altura para as médias de velocidade do vento. 
comparações múltiplas identificando e quantificando as diferenças. Para tal objetivo foi realizado o teste de Tukey.

Tabela 8. Análise de Covariância para a velocidade do vento

\begin{tabular}{lccccc}
\hline Fonte & GL & SQ & QM & F & P \\
\hline Vento externo $(\mathrm{m} / \mathrm{s})$ & 1 & 0,014397 & 0,014397 & 7,28 & 0,007 \\
Data & 1 & 0,022243 & 0,022243 & 11,25 & 0,001 \\
Altura $(\mathrm{m})$ & 2 & 0,050717 & 0,025358 & 12,82 & 0,000 \\
Pontos & 7 & 0,058956 & 0,008422 & 4,26 & 0,000 \\
Manejo & 2 & 0,577363 & 0,288682 & 145,98 & 0,000 \\
Altura*Manejo & 4 & 0,003779 & 0,000945 & 0,48 & 0,752 \\
Pontos*Manejo & 14 & 0,04694 & 0,003353 & 1,7 & 0,053 \\
Altura*Pontos & 14 & 0,01389 & 0,000992 & 0,5 & 0,932 \\
Altura*Pontos*Manejo & 28 & 0,043314 & 0,001547 & 0,78 & 0,782 \\
Erro & 497 & 0,982842 & 0,001978 & & \\
Total & 570 & & & & \\
\hline
\end{tabular}

Nas Tabelas 9, 10, 11 e 12, observa-se os valores médios de velocidade do vento para os níveis do fator dia, altura de coleta, pontos de coleta e manejo da cortina, respectivamente. Mostra-se ainda, a significância da diferença entre as médias através da codificação ordenada por letras. As letras em ordem crescente do alfabeto correspondem à magnitude das médias em ordem crescente. Médias com mesmas letras não são significativamente diferentes. Conforme o resultado apresentado na Tabela 9, o dia 30/abril apresentou maior média de velocidade do vento significativamente diferente da média de velocidade do vento do dia 29/abril, comprovando o exposto pela Figura 21. 
Tabela 9. Comparação das médias da velocidade do vento para os dias de coleta, através do teste de Tukey

\begin{tabular}{lll}
\hline Data & Média & N \\
\hline 30/abr & $0,151626 \mathrm{a}$ & 289 \\
29/abr & $0,126983 \mathrm{~b}$ & 287 \\
\hline
\end{tabular}

A Tabela 10 evidencia maiores médias de velocidade do vento para as alturas de 3,0 e 2,0 m, não sendo diferenciadas significativamente entre si. Isso se explica pelas dimensões das aberturas laterais (janelas) da sala de maternidade que abrangem a altura de 1,5 até 3,0 m do piso, ou seja, essas duas alturas de coleta recebem o vento externo diretamente sem percorrer qualquer obstáculo, concordando com Abreu \& Abreu (2005), que afirmam que para ter-se ventilação verdadeiramente efetiva as aberturas devem estar em paredes opostas e com o mínimo de obstáculos em seu caminho.

A altura de $1,0 \mathrm{~m}$ apresentou a menor média de velocidade do vento, significativamente diferente dos outras duas alturas de coleta e, mesmo assim, em conformidade com Moura (1999), que recomenda a velocidade incidente diretamente sobre os leitões na faixa de 0,1 a $0,2 \mathrm{~m} / \mathrm{s}$ e sobre as matrizes na faixa de 0,1 a $0,3 \mathrm{~m} / \mathrm{s}$. Esse resultado da altura de $1,0 \mathrm{~m}$ apresentar a menor média e significativamente diferente das demais é totalmente justificável, pois acima da altura de $1,0 \mathrm{~m}$ se encontram os muros das laterais da instalação e as baias onde ficam alojados os animais. $\mathrm{O}$ ajuste das aberturas para a entrada de ar através do manejo das cortinas, de acordo com Morsing et al. (2000), pode prejudicar a ventilação e renovação de ar na altura dos animais, justamente pelo fato do excesso de vento na altura do tratador sugerir a necessidade do fechamento das cortinas. 
Tabela 10. Comparação das médias da velocidade do vento para as alturas de coleta, através do teste de Tukey

\begin{tabular}{cll}
\hline Altura (m) & Média & N \\
\hline 2,0 & $0,148160 \mathrm{a}$ & 188 \\
3,0 & $0,143401 \mathrm{a}$ & 197 \\
1,0 & $0,126492 \mathrm{~b}$ & 191 \\
\hline
\end{tabular}

Na Figura 26, podem-se visualizar essas variações em função da altura de coleta dos dados de velocidade do vento no corte longitudinal da instalação, na condição de manejo da cortina totalmente aberta. Percebe-se que na altura de $1 \mathrm{~m}$ do piso, devido à velocidade do vento ser menor, a região é mais escura podendo ser interpretada por uma zona de maior desconforto térmico e menor renovação de ar. Enquanto que nas alturas de 2,0 e 3,0 m, observam-se regiões mais claras indicando velocidades de vento maiores.
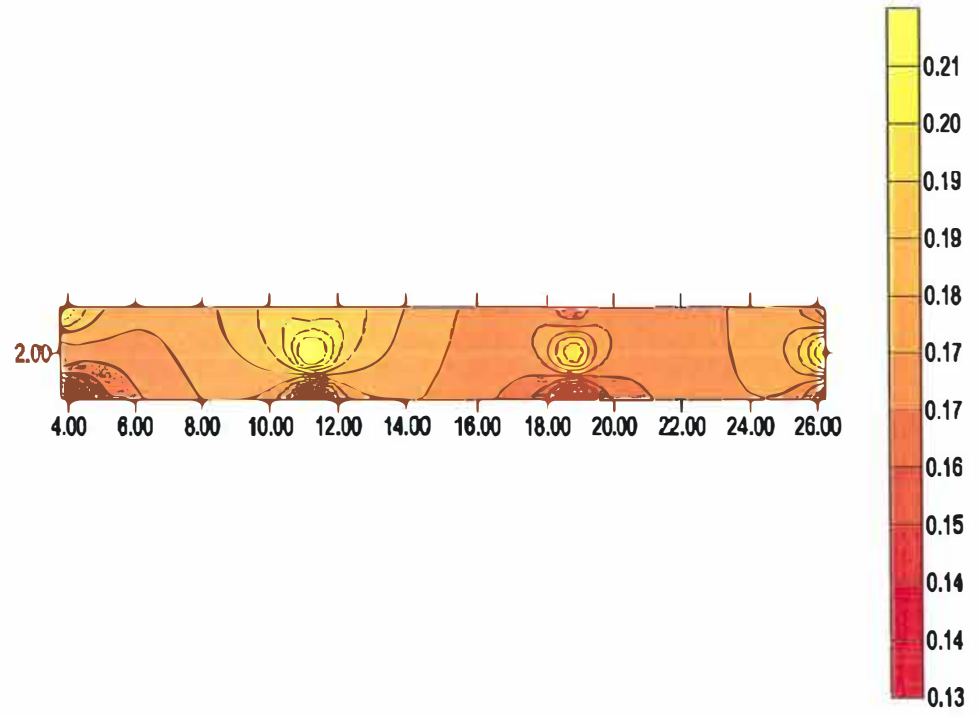

Figura 26 - Perfil do corte longitudinal da distribuição da velocidade do vento na instalação, sobre a condição de manejo da cortina (A)

A Tabela 11 mostra que houve diferença significativa da média da velocidade do vento entre alguns pontos de coleta no interior da instalação, como demonstrou a Figura 23, comprovando haver diferenciação local do efeito da ventilação natural, ou seja, que 
esta não se distribui homogeneamente na sala de maternidade. Avaliação semelhante foi realizada por Miragliotta (2004) em galpões para produção de frangos, onde foram detectadas distribuições não homogêneas de temperatura, umidade, luminosidade e vento, neste caso, utilizando a geoestatística como ferramenta de análise dos dados climáticos obtidos.

Através das Figuras 27 e 28, pode-se visualizar melhor a distribuição e o comportamento do vento no interior da sala. Na Figura 27, para a condição de manejo (AF), observa-se uma maior velocidade do vento próxima à abertura de entrada dos ventos dominantes como era esperado. $\mathrm{O}$ vento então se distribui homogeneamente no interior da sala diminuindo sua velocidade em direção à abertura oposta. Na Figura 28, para a condição de manejo $(\mathrm{F})$, percebe-se uma distribuição menos homogênea do vento com maior velocidade na lateral oposta, que está aberta.

Tabela 11. Comparação das médias da velocidade do vento para os pontos de coleta, através do teste de Tukey

\begin{tabular}{cll}
\hline Pontos & Média & N \\
\hline 1 & $0,156901 \mathrm{a}$ & 71 \\
8 & $0,146164 \mathrm{~b} \mathrm{a}$ & 73 \\
2 & $0,141972 \mathrm{~b} \mathrm{a} \mathrm{c}$ & 71 \\
7 & $0,141507 \mathrm{~b} \mathrm{a} \mathrm{c}$ & 73 \\
6 & $0,140685 \mathrm{~b} \mathrm{a} \mathrm{c}$ & 73 \\
4 & $0,140139 \mathrm{~b} \mathrm{a} \mathrm{c}$ & 72 \\
5 & $0,123889 \mathrm{~b} \mathrm{c}$ & 72 \\
3 & $0,123437 \mathrm{c}$ & 71 \\
\hline
\end{tabular}



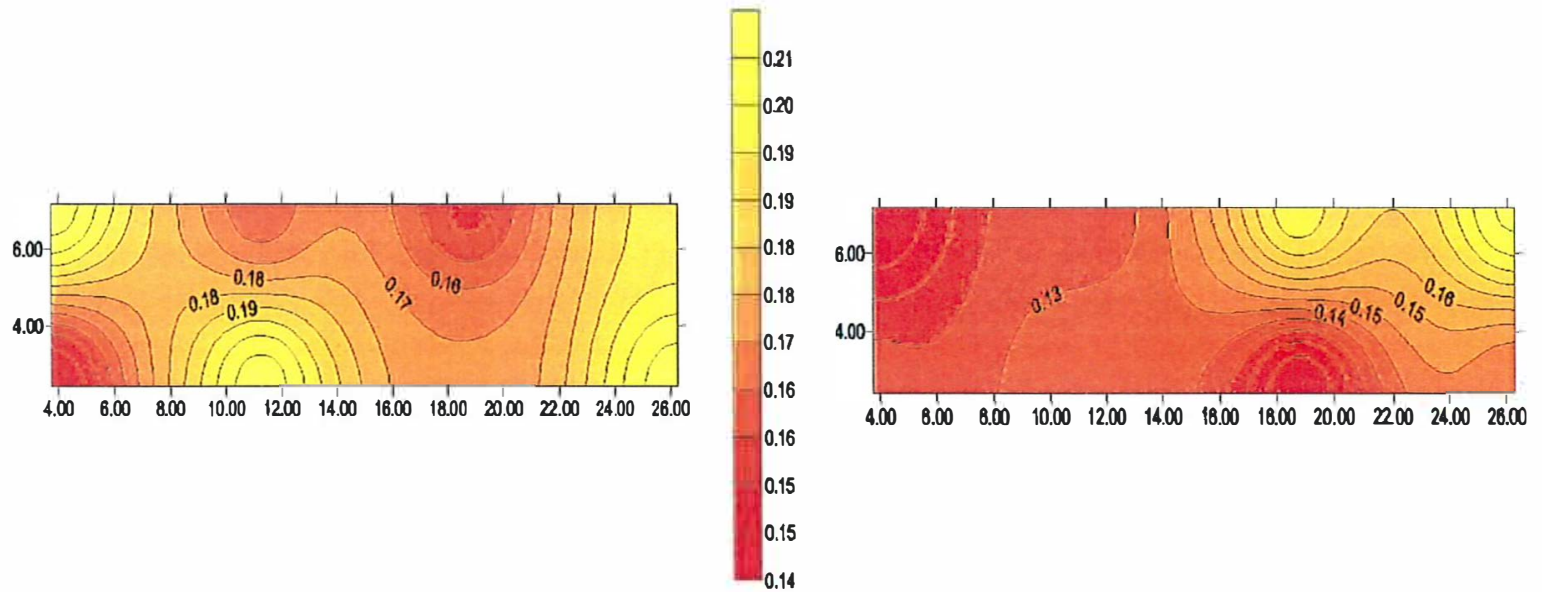

Figura 27 - Perfil horizontal de distribuição da velocidade do vento na altura

Figura $28-$ Perfil horizontal de distribuição da de 2,0m, para a condição de velocidade do vento manejo da cortina (AF) na altura de 2,0m, para a condição de manejo da cortina $(\mathrm{F})$

Por fim, a Tabela 12, demonstra diferença significativa entre os manejos da cortina estudados, conforme apresentou a Figura 24. A sala da maternidade sob a condição de manejo totalmente aberta apresentou as maiores médias de velocidade do vento e significativamente diferente da condição de manejo totalmente fechada, como esperado. Essa diferença pode ser melhor visualizada pela Figura 30, juntamente com a Figura 26 anterior, onde percebe-se um perfil mais claro para a condição de manejo (A) e mais escuro para a condição de manejo (F). Observa-se, também, que esta última condição apresenta regiões com maior velocidade do vento no canto esquerdo, devido a presença de uma abertura de acesso aos funcionários e aos animais e, mesmo assim, a média da velocidade do vento não atingiu a faixa ideal proposta por Moura (1999).

Comparando a Figura 26 com a Figura 29, observa-se uma semelhança que foi comprovada na Tabela 12, onde não houve diferença significativa entre a condição de manejo (A) e (AF). Isso pode ser explicado, pelo aumento de vazão que a o manejo (AF) ocasiona devido a redução da área de abertura para entrada do vento. 
Tabela 12. Comparação das médias da velocidade do vento para os manejos da cortina, através do teste de Tukey

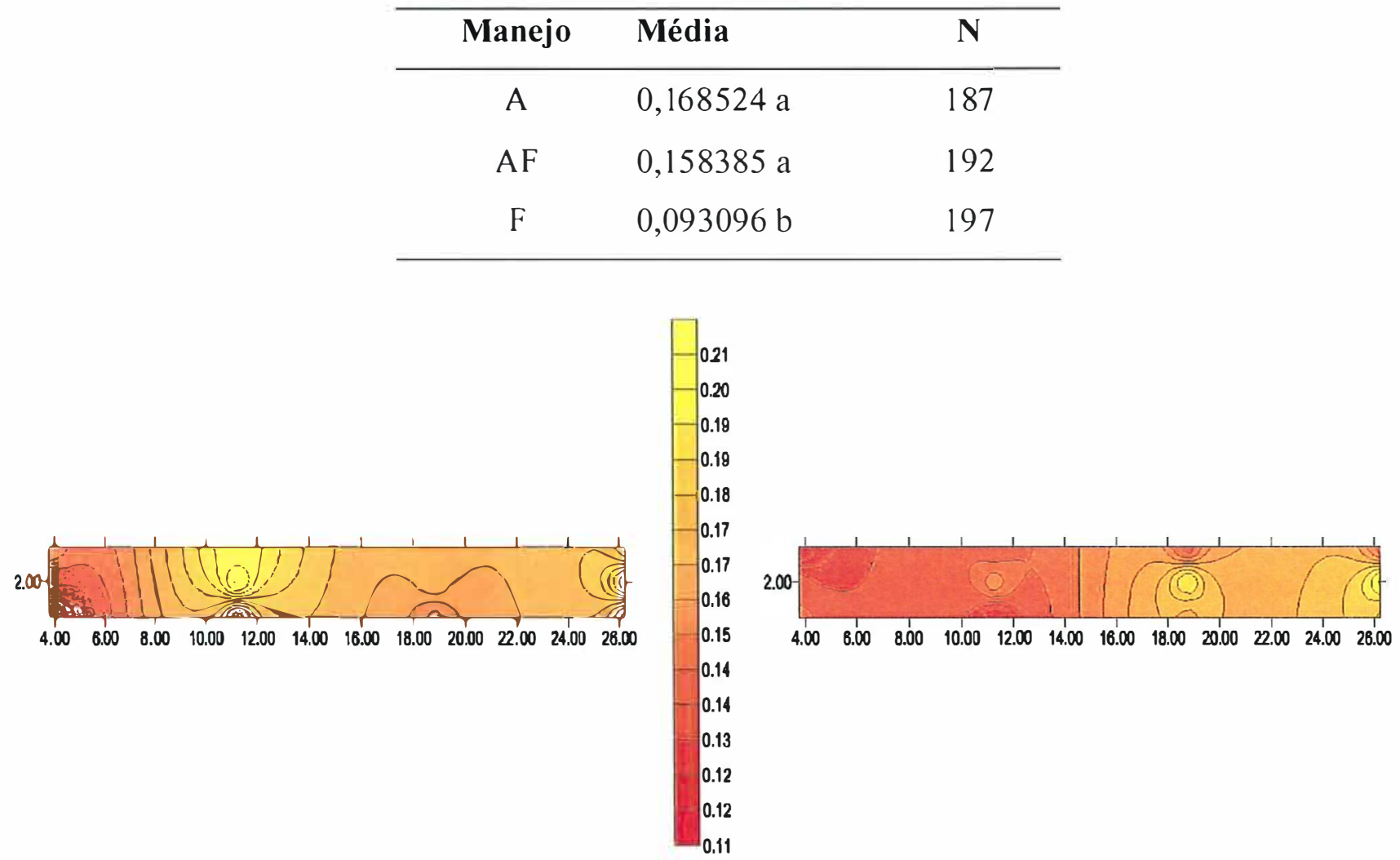

Figura 29 - Perfil do corte longitudinal de Figura 30 - Perfil do corte longitudinal de distribuição da velocidade do vento na instalação sobre a condição de manejo da cortina (AF) distribuição da velocidade do vento na instalação sobre a condição de manejo da cortina (F)

\subsection{Análise dos dados da temperatura superficial dos pisos dos escamoteadores}

\subsubsection{Análise descritiva}

Nas Tabelas 13, 14 e 15, apresenta-se a análise descritiva para o fator tipo de aquecimento, manejo da cortina e dia de coleta, respectivamente. 
Tabela 13. Resultado da análise descritiva dos tipos de aquecimento: piso térmico (P) e lâmpada incandescente (L), para a temperatura superficial dos pisos

\begin{tabular}{lccccccccc}
\hline Variável & Aquec. & $\mathbf{N}$ & \multicolumn{1}{c}{ Média } & Mediana & Desv.Padrão Min. & Máx. & Q1 & Q3 \\
Temperatura & $\mathrm{L}$ & 1296 & 25,738 & 26 & 2,007 & 22 & 31 & 24 & 27 \\
do piso $\left({ }^{\circ} \mathrm{C}\right)$ & $\mathrm{P}$ & 1296 & 26,269 & 26 & 2,423 & 22 & 36 & 24 & 28 \\
\hline
\end{tabular}

Tabela 14. Resultado da análise descritiva dos manejos da cortina: totalmente aberto (A), semi-aberto (AF) e totalmente fechado (F), para a temperatura superficial dos pisos

\begin{tabular}{lccccccccc}
\hline Variável & Manejo & N & Média & Mediana Desv.Padrão & Mín. & Máx. & Q1 & Q3 \\
\hline Temperatura & $\mathrm{A}$ & 864 & 26,572 & 27 & 2,329 & 22 & 34 & 25 & 28 \\
do piso $\left({ }^{\circ} \mathrm{C}\right)$ & $\mathrm{AF}$ & 864 & 25,84 & 26 & 2,191 & 22 & 36 & 24 & 27 \\
& $\mathrm{~F}$ & 864 & 25,598 & 26 & 2,08 & 22 & 33 & 24 & 27 \\
\hline
\end{tabular}

Tabela 15. Resultado da análise descritiva dos dias de coleta dos dados, para a temperatura superficial dos pisos

\begin{tabular}{lccccccccc}
\hline Variável & Dia & N & Média & Mediana & Desv.Padrão & Mín. Máx. Q1 & Q3 \\
\hline Temperatura & 14/abr & 648 & 25,833 & 26 & 1,783 & 22 & 31 & 24 & 27 \\
do piso $\left({ }^{\circ} \mathrm{C}\right)$ & $15 / a b r$ & 648 & 27,099 & 27 & 2,201 & 22 & 36 & 26 & 28 \\
& 29/abr & 648 & 26,423 & 27 & 2,349 & 22 & 34 & 24 & 28 \\
& $30 / a b r$ & 648 & 24,659 & 24 & 1,828 & 22 & 32 & 23 & 26 \\
\hline
\end{tabular}

\subsubsection{Análise exploratória}

Observa-se na Figura 31 que apenas no dia 30/abril a temperatura superficial dos pisos permaneceu mais quente para a condição de manejo da cortina $(\mathrm{F})$ do que para a condição de manejo (A) e (AF). Nos demais dias, a temperatura superficial dos pisos permaneceu mais quente para a condição de manejo (A) do que para a condição de manejo $(\mathrm{AF})$ e $(\mathrm{F})$. Isso pode ser explicado pela influência da temperatura ambiente 


\subsubsection{Análise confirmatória}

\subsubsection{Análise para o dia mais frio}

Analisando os dados da Figura 33, observa-se que em dias mais frios ocorre uma perda de calor entre a superficie do piso e o ar. Já em dias mais quentes ocorre o inverso, um acréscimo na temperatura superficial dos pisos devido ao ar estar mais quente. Esses resultados concordam com os obtidos por Zhang et al. (2001), que afirmaram que a convecção natural devido às trocas de calor interfere na variação da temperatura no interior dos escamoteadores, afetando os gradientes de temperatura nesse local.

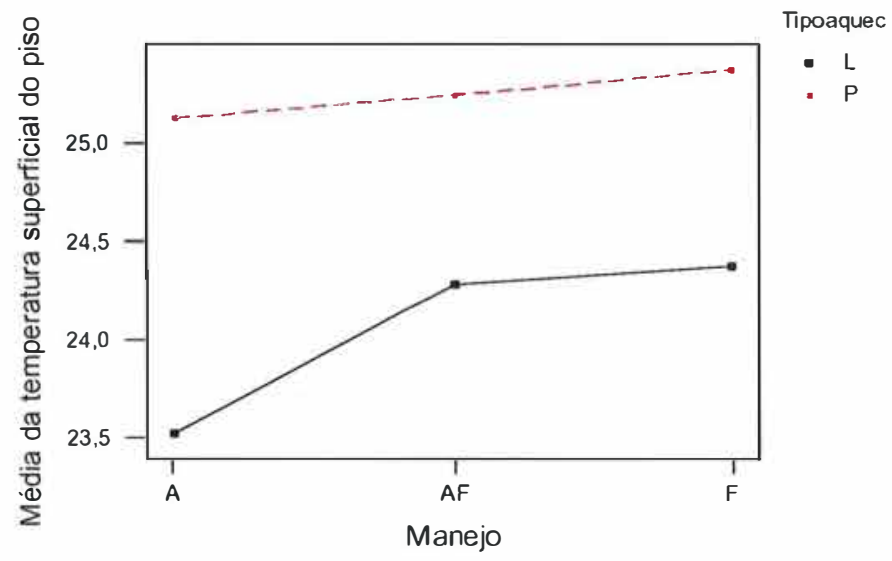

Figura 33 - Interação dos diferentes manejos da cortina com os tipos de aquecimento (L = lâmpada e $\mathrm{P}=$ Piso térmico) na temperatura superficial dos pisos $\left({ }^{\circ} \mathrm{C}\right)$ para o dia mais frio

Conforme pode ser observado na Tabela 16, houve interação significativa entre os fatores tipos de aquecimento e os diferentes manejos da cortina $(p=0,000)$. Na Figura 33, onde se encontra a representação gráfica desta interação na temperatura superficial dos pisos para o dia mais frio (30/abril), observa-se que a superfície dos pisos dos escamoteadores aquecidos pelo sistema de piso térmico permaneceu mais estável que os pisos dos escamoteadores aquecidos por lâmpadas incandescentes. 
externa nos dias avaliados, conforme pode ser observado na Figura 32.

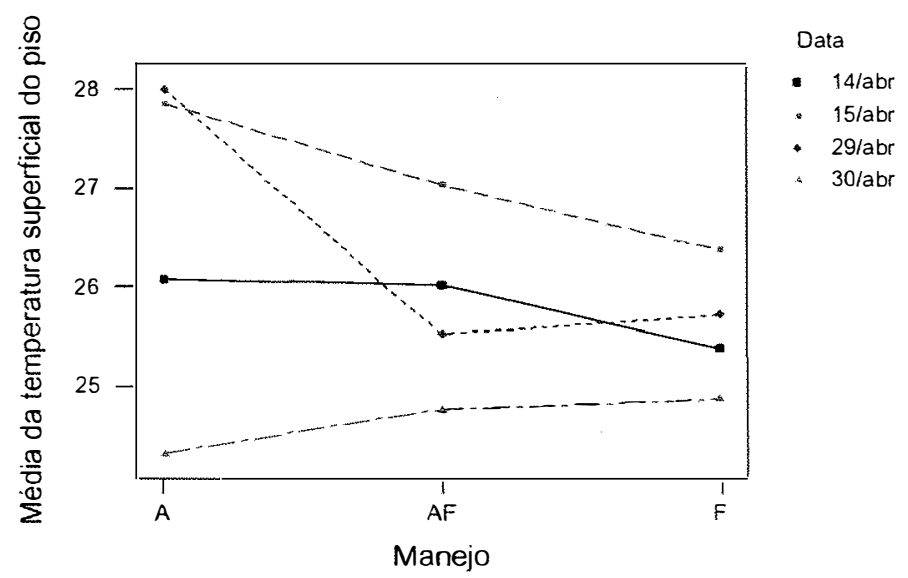

Figura 31 - Interação dos diferentes manejos da cortina com os dias de coleta na média da temperatura superficial dos pisos $\left({ }^{\circ} \mathrm{C}\right)$

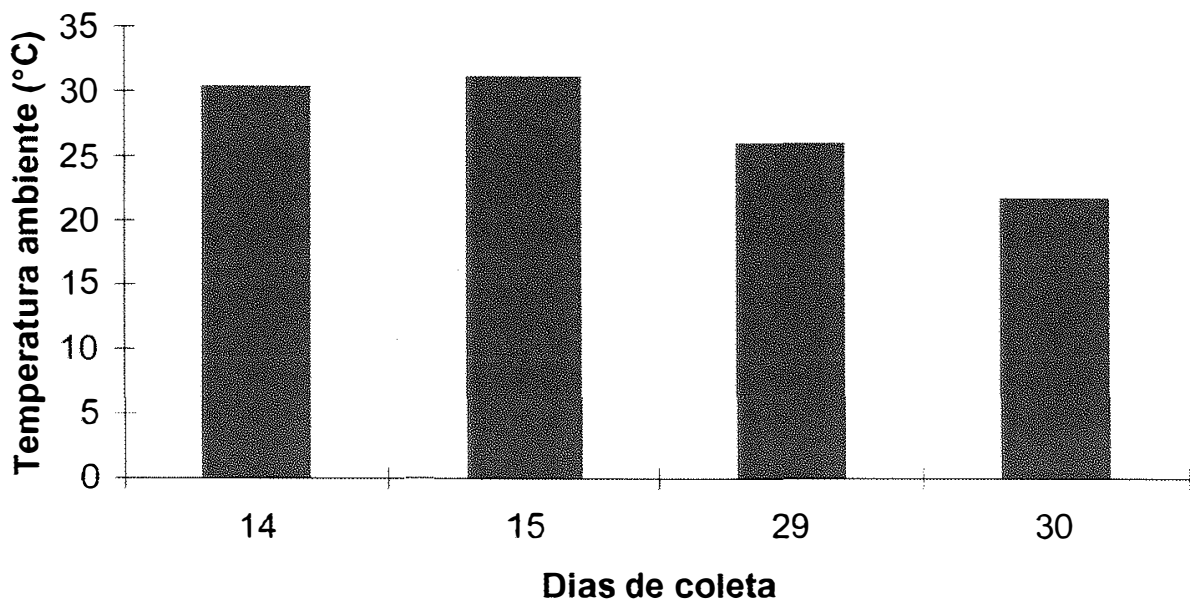

Figura 32 - Representação gráfica da temperatura ambiente externa para as diversas datas avaliadas

Essas análises prévias sugerem uma certa precaução no estudo das trocas térmicas para os diferentes tipos de manejos e sistemas de aquecimento em função da temperatura do dia. Desta forma, será analisado a interação do manejo da cortina e do tipo de aquecimento para os dias de temperaturas extremas. 
Isso pode ser comprovado pelo resultado do teste de Tukey, apresentado na Tabela 17, onde demonstra-se não haver diferença significativa nas médias da temperatura superficial dos pisos dos escamoteadores aquecidos por pisos térmicos com qualquer uma das condições de manejos da cortina. O mesmo não acontece com as médias da temperatura superficial dos pisos dos escamoteadores aquecidos por lâmpadas, onde comprova-se haver diferença significativa para as condições de manejo da cortina (F) com (A) e (AF) com (A).

Tabela 16. Resultado da Análise de Covariância para a temperatura superficial do piso

\begin{tabular}{lccccc}
\hline Fonte & GL & SQ & QM & F & P \\
\hline Vento $(\mathrm{m} / \mathrm{s})$ & 1 & 9,725 & 9,725 & 3,45 & 0,064 \\
Temperatura $\left({ }^{\circ} \mathrm{C}\right)$ & 1 & 11,022 & 11,022 & 3,91 & 0,048 \\
UR (\%) & 1 & 64,778 & 64,778 & 23,01 & 0,000 \\
Tipo aquecimento & 1 & 91,107 & 91,107 & 32,36 & 0,000 \\
Manejo & 1 & 112,023 & 56,012 & 19,89 & 0,000 \\
Tipoaque*Manejo & 1 & 66,443 & 33,221 & 11,8 & 0,000 \\
Erro & 639 & 1799,134 & 2,816 & & \\
Total & 647 & & & & \\
\hline
\end{tabular}

Tabela 17. Comparação das médias da temperatura superficial dos pisos para a interação dos manejos da cortina com os tipos de aquecimento, através do teste de Tukey

\begin{tabular}{cll}
\hline Manejo & Média & N \\
\hline PF & $25,3796 \mathrm{a}$ & 108 \\
PAF & $25,2500 \mathrm{a}$ & 108 \\
PA & $25,1296 \mathrm{a}$ & 108 \\
LF & $24,3796 \mathrm{~b}$ & 108 \\
LAF & $24,2870 \mathrm{~b}$ & 108 \\
LA & $23,5278 \mathrm{c}$ & 108 \\
\hline
\end{tabular}




\subsubsection{Análise para o dia mais quente}

Conforme pode ser observado na Tabela 18, houve interação significativa entre os fatores tipos de aquecimento e os diferentes manejos da cortina $(p=0,008)$. Na Figura 34, onde se encontra a representação gráfica desta interação na temperatura superficial dos pisos para o dia mais quente (15/abril), observa-se uma similaridade de comportamento entre os dois tipos de aquecimento.

Isso pode ser comprovado pelo resultado do teste de Tukey, apresentado na Tabela 19, onde demonstra-se haver diferença significativa nas médias da temperatura superficial dos pisos de escamoteadores aquecidos por pisos térmicos entre as condição de manejo (A) e $(F)$ e $(A)$ e $(A F)$. Menores diferenças significativas ocorrem para as médias de temperatura superficial dos pisos dos escamoteadores aquecidos por lâmpadas onde apenas ocorrem entre as condições de manejo (F) e (A).

Tabela 18. Análise da Covariância para a temperatura do piso

\begin{tabular}{lccccc}
\hline Fonte & GL & SQ & QM & F & P \\
\hline Vento (m/s) & 1 & 78,98 & 78,98 & 28,42 & 0,000 \\
Temperatura $\left({ }^{\circ} \mathrm{C}\right)$ & 1 & 158,24 & 158,24 & 56,94 & 0,000 \\
UR (\%) & 1 & 14,92 & 14,92 & 5,37 & 0,021 \\
Tipo aquecimento & 1 & 654,4 & 654,4 & 235,46 & 0,000 \\
Manejo & 2 & 184,53 & 92,27 & 33,2 & 0,000 \\
Tipoaque*Manejo & 2 & 26,73 & 13,36 & 4,81 & 0,008 \\
Erro & 639 & 1775,91 & 2,78 & & \\
Total & 647 & & & & \\
\hline
\end{tabular}




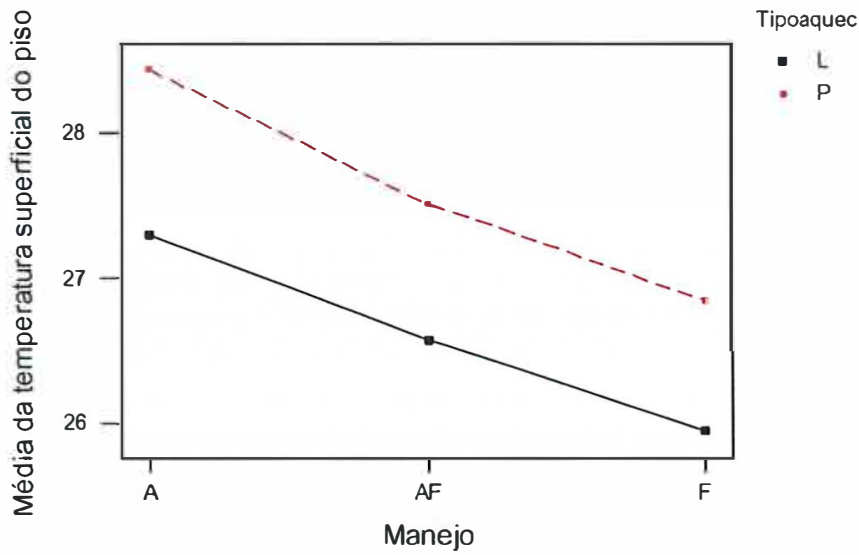

Figura 34 - Interação dos diferentes manejos da cortina com os tipos de aquecimentos na temperatura superficial dos pisos $\left({ }^{\circ} \mathrm{C}\right)$ para o dia mais quente

Tabela 19. Comparação das médias da temperatura superficial dos pisos para a interação dos manejos da cortina com os tipos de aquecimento, através do teste de Tukey

\begin{tabular}{cll}
\hline Manejo & Média & N \\
\hline PA & $28,4352 \mathrm{a}$ & 108 \\
PAF & $27,5093 \mathrm{~b}$ & 108 \\
LA & $27,2963 \mathrm{c} \mathrm{b}$ & 108 \\
PF & $26,8426 \mathrm{c} \mathrm{b}$ & 108 \\
LAF & $26,5648 \mathrm{c} \mathrm{d}$ & 108 \\
LF & $25,9444 \mathrm{~d}$ & 108 \\
\hline
\end{tabular}

Pode-se concluir, então, que o sistema de aquecimento por piso térmico sofre menor influência (perde menos calor) em função da ventilação externa em comparação com o sistema de aquecimento por lâmpadas em dias mais frios. Porém em temperaturas mais altas, no período diurno em que o sistema de aquecimento não é tão requisitado, o escamoteador aquecido por pisos térmicos sofre maior influência que o sistema de aquecimento por lâmpadas, ou seja, ganha mais calor em função da ventilação natural. Isso pode ser facilmente controlado pelo reajuste do termostato do piso térmico para uma faixa de temperatura inferior. 
Explicam-se esses resultados pela diferente forma de transferência de calor entre os dois sistemas de aquecimento. Os pisos térmicos fornecem calor através da condução enquanto as lâmpadas incandescentes, através da convecção e irradiação.

\subsubsection{Teste não-paramétrico para a locação (teste para medianas) da distribuição da temperatura superficial nos pisos}

Realizou-se o teste para medianas para avaliar a homogeneidade da distribuição da temperatura superficial dos pisos, para os dois sistemas de aquecimento. Esse teste simplifica consideravelmente a informação, ao verificar apenas, se uma observação está abaixo ou acima da mediana geral. O intervalo de confiança para a homogeneidade ao nível de significância de $95 \%$ é $-1,96<Z<1,96$, ou seja, os quadrantes com valores entre esse intervalo são considerados homogêneos. As medianas da temperatura superficial do piso nos quadrantes que ultrapassam o limite inferior ou superior de homogeneidade, se encontram destacadas pelo asterisco. Nas Tabelas 20 e 21, observase os resultados do teste de Kruskal-Wallis para o sistema de aquecimento por piso térmico e por lâmpadas, respectivamente. 
Tabela 20. Resultados do teste de Kruskal-Wallis para a distribuição da temperatura superficial $\left({ }^{\circ} \mathrm{C}\right)$ nos pisos dos escamoteadores aquecidos por piso térmico

\begin{tabular}{|c|c|c|c|c|}
\hline Quadrante & $\mathbf{N}$ & Mediana & Posto Médio & $\mathbf{Z}$ \\
\hline Q1 & 108 & 26 & 582,7 & $-1,91$ \\
\hline Q10 & 72 & 25 & 499,2 & $-3,48 *$ \\
\hline Q11 & 36 & 27 & 823,2 & $2,84^{*}$ \\
\hline Q12 & 72 & 27 & 725,4 & 1,79 \\
\hline Q13 & 72 & 26 & 562,9 & $-2,00 *$ \\
\hline Q14 & 36 & 27 & 832,7 & $3,00^{*}$ \\
\hline Q15 & 72 & 26,5 & 688,4 & 0,93 \\
\hline Q16 & 108 & 25 & 483,6 & $-4,78^{*}$ \\
\hline Q17 & 72 & 26 & 696,9 & 1,13 \\
\hline Q18 & 108 & 26 & 601,1 & $-1,38$ \\
\hline Q2 & 72 & 27 & 802,4 & $3,59 *$ \\
\hline Q3 & 108 & 26 & 696,1 & 1,38 \\
\hline Q4 & 72 & 25 & 555,2 & $-2,18^{*}$ \\
\hline Q5 & 36 & 27 & 820,6 & $2,80 *$ \\
\hline Q6 & 72 & 27 & 749,4 & $2,35^{*}$ \\
\hline Q7 & 72 & 25 & 499,4 & $-3,48^{*}$ \\
\hline Q8 & 36 & 27 & 776,8 & $2,09 *$ \\
\hline Q9 & 72 & 27 & 722 & 1,71 \\
\hline Overall & 1296 & 648,5 & & \\
\hline
\end{tabular}


Tabela 21. Resultado do teste de Kruskal-Wallis para a distribuição da temperatura nos pisos $\left({ }^{\circ} \mathrm{C}\right)$ dos escamoteadores aquecidos por lâmpadas

\begin{tabular}{ccccc}
\hline Quadrante & N & Mediana & Posto Médio & Z \\
\hline Q1 & 108 & 25 & 556,2 & $-2,68^{*}$ \\
Q10 & 72 & 26 & 623,7 & $-0,58$ \\
Q11 & 36 & 26,5 & 747,8 & 1,61 \\
Q12 & 72 & 25,5 & 603 & $-1,06$ \\
Q13 & 72 & 26 & 655,6 & 0,17 \\
Q14 & 36 & 27 & 787,1 & $2,25 *$ \\
Q15 & 72 & 26 & 653 & 0,11 \\
Q16 & 108 & 27 & 747,5 & $2,87^{*}$ \\
Q17 & 72 & 27 & 844,6 & $4,58^{*}$ \\
Q18 & 108 & 26 & 738,8 & $2,62^{*}$ \\
Q2 & 72 & 26 & 674,3 & 0,6 \\
Q3 & 108 & 26 & 624,1 & $-0,71$ \\
Q4 & 72 & 25 & 533,4 & $-2,69^{*}$ \\
Q5 & 36 & 26 & 651,8 & 0,05 \\
Q6 & 72 & 25 & 543,8 & $-2,44^{*}$ \\
Q7 & 72 & 25 & 546,1 & $-2,39 *$ \\
Q8 & 36 & 26 & 687,1 & 0,63 \\
Q9 & 72 & 25 & 558,8 & $-2,09^{*}$ \\
Overall & 1296 & 648,5 & & \\
\hline & & & &
\end{tabular}

O teste para os pisos térmicos resultou em 11 quadrantes discrepantes e o teste para as lâmpadas incandescentes, 9 quadrantes. Para verificar se houve diferença significativa na magnitude de heterogeneidade entre esses dois sistemas de aquecimento, realizou-se o teste para diferentes proporções.

Conforme pode ser observado na Tabela 22, não houve diferença significativa na heterogeneidade da distribuição da temperatura superficial dos pisos dos escamoteadores 
aquecidos por lâmpadas e por pisos térmicos, ou seja, ambos foram igualmente heterogêneos. Os pisos dos escamoteadores aquecidos por lâmpadas apresentam, conforme pode ser visualizado na Figura 35, uma maior estratificação na distribuição da temperatura superficial, pois o aquecimento é fornecido de um único local (extremidade) onde a região permanece mais quente. Já os pisos dos escamoteadores equipados por piso térmico apresentam, conforme pode ser visualizado na Figura 36, uma diferença de temperatura superficial em determinados pontos, podendo ser explicada pela presença de urina e/ou dejetos e na região próxima a abertura de acesso aos leitões.

Resultados semelhantes foram obtidos por Xin \& Zhang (1999), Zhang \& Xin (2001) e Pandorfi (2002), onde obteve-se o mesmo perfil de temperatura quando comparados escamoteadores aquecidos por lâmpadas (perfil mais estratificado) com escamoteadores aquecidos por pisos térmicos (perfil mais homogêneo). Esse perfil de estratificação dos pisos dos escamoteadores aquecidos por pisos térmicos e por lâmpadas, pode ser visualizado na Figura 37.

Na Figura 37 (a) observa-se que a temperatura da superficie do piso do escamoteador aquecido por lâmpada varia ao longo do piso, indicando que o aquecimento por lâmpadas possui uma pequena área embaixo da lâmpada bem aquecida, e que, conforme se afasta desta área, o aquecimento é reduzido. Enquanto que na Figura 37 (b), observa-se que a temperatura do piso do escamoteador aquecido por piso térmico também varia em função da distância, mas não devido ao provimento de calor localizado e sim, pela influência do vento que entra pela abertura de acesso dos leitões.

Ł̀ importante salientar que as temperaturas obtidas neste estudo foram influenciadas pela necessidade de se abrir o escamoteador para que fosse possível mensurar as temperaturas do piso com o termômetro infravermelho, o que reduziu em alguns casos, as temperaturas a níveis mais baixos do que os recomendados por Perdomo (1987), $32^{\circ} \mathrm{C}$. 
Tabela 22. Resultado do teste para diferentes proporções $(\mathrm{L}=$ lâmpada e $\mathrm{P}=$ piso térmico)

\begin{tabular}{cccc}
\hline Aquecimento & N & Amostra & P \\
\hline L & 9 & 18 & 0,5 \\
P & 11 & 18 & 0,611 \\
\hline
\end{tabular}

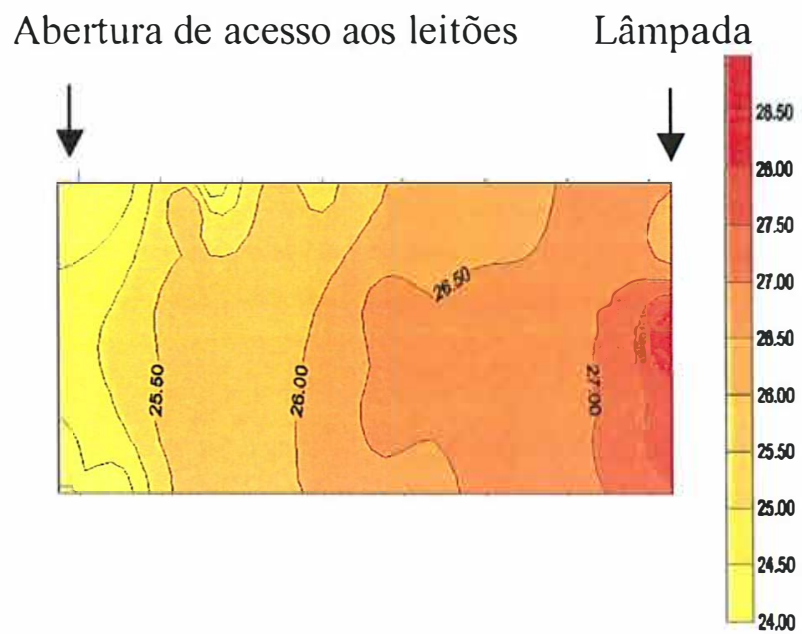

Abertura de acesso aos leitões

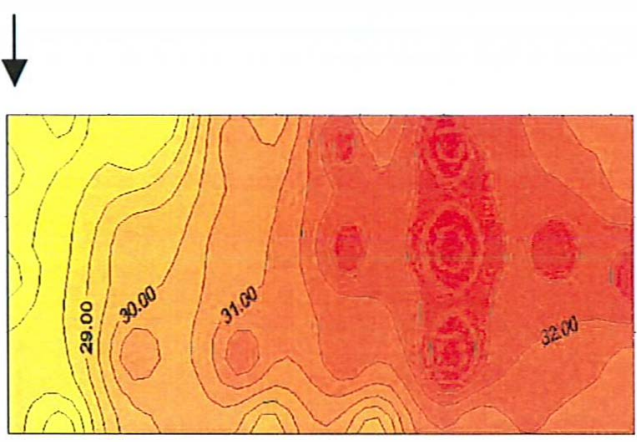

Figura 35 - Representação das isotermas do Figura 36 - Representação das isotermas piso do escamoteador aquecido por lâmpada

do piso do escamoteador aquecido por piso térmico

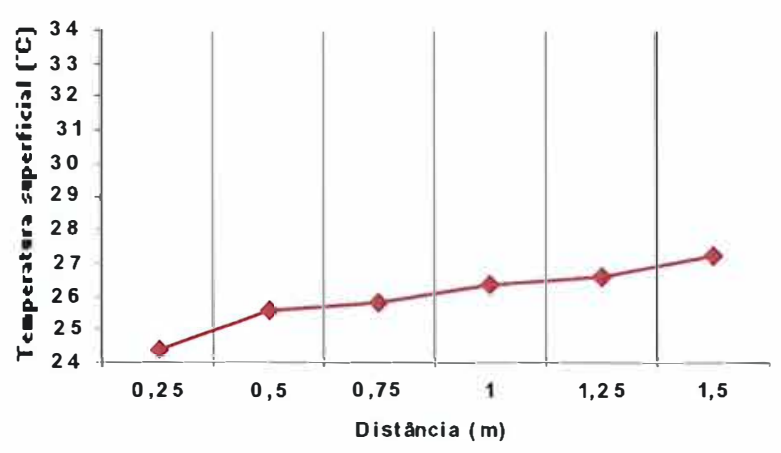

(a)

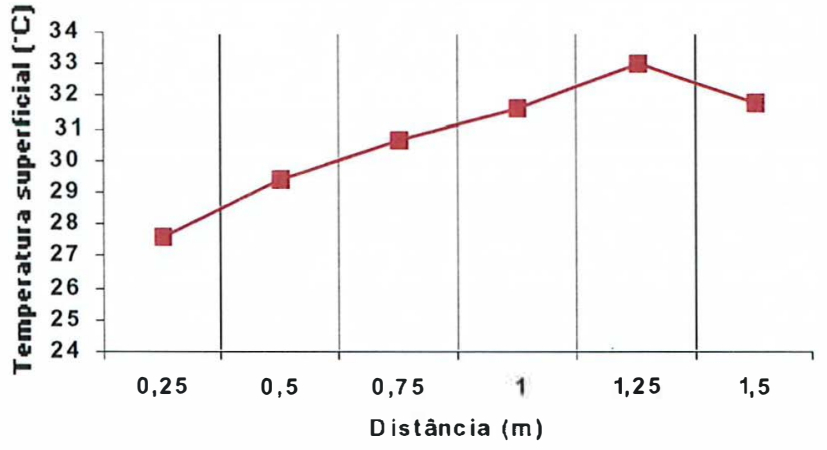

(b)

Figura 37 - Variação da temperatura superficial em função da distância para lâmpadas incandescentes (a) e para pisos térmicos (b) 


\subsection{Análise dos dados de temperatura no interior da sala}

\subsubsection{Análise descritiva}

Nas Tabelas 23, 24 e 25, apresenta-se a análise descritiva para o fator dias de coleta, pontos de coleta e manejos da cortina, respectivamente.

Tabela 23. Resultado da análise descritiva dos dias de coleta para a temperatura interna da sala

\begin{tabular}{lccccccccc}
\hline Variável & Data & N & Média & Mediana & Desv.Padrão & Mín. & Máx. & Q1 & Q3 \\
\hline Temperatura & 29/abr & 24 & 24,773 & 25,56 & 1,488 & 22,09 & 26,34 & 23,025 & 25,95 \\
$\left({ }^{\circ} \mathrm{C}\right)$ & $30 / \mathrm{abr}$ & 24 & 21,724 & 20,95 & 1,398 & 20,19 & 25,17 & 20,57 & 23,18
\end{tabular}

Tabela 24. Resultado da análise descritiva dos pontos de coleta para a temperatura interna da sala

\begin{tabular}{lccccccccc}
\hline Variável & Ponto & $\mathbf{N}$ & Média & Mediana & Desv.Padrão & Mín. & Máx. & Q1 & Q3 \\
\hline Temperatura & 1 & 6 & 24,21 & 24,21 & 1,37 & 22,48 & 25,56 & 23,05 & 25,56 \\
$\left({ }^{\circ} \mathrm{C}\right)$ & 2 & 6 & 22,94 & 22,67 & 2,42 & 20,19 & 25,95 & 20,48 & 25,66 \\
& 3 & 6 & 22,94 & 22,67 & 2,42 & 20,19 & 25,95 & 20,48 & 25,66 \\
& 4 & 6 & 23,13 & 23,05 & 2,34 & 20,19 & 25,95 & 20,76 & 25,66 \\
& 5 & 6 & 23,13 & 23,05 & 2,32 & 20,20 & 26,00 & 20,80 & 25,63 \\
& 6 & 6 & 23,21 & 23,12 & 2,25 & 20,57 & 26,10 & 20,86 & 25,58 \\
& 7 & 6 & 23,19 & 22,67 & 2,32 & 20,95 & 26,34 & 20,95 & 25,76 \\
& 8 & 6 & 23,25 & 22,86 & 2,28 & 20,95 & 26,34 & 20,95 & 25,76 \\
\hline
\end{tabular}


Tabela 25. Resultado da análise descritiva dos diferentes manejos da cortina para a temperatura interna da sala

\begin{tabular}{lccccccccc}
\hline Variável & Manejo & N & Média & Mediana & Desv.Padrão & Mín. & Máx. & Q1 & Q3 \\
\hline Temperatura & $\mathrm{A}$ & 16 & 21,79 & 22,29 & 1,26 & 20,19 & 23,24 & 20,29 & 22,97 \\
$\left({ }^{\circ} \mathrm{C}\right)$ & $\mathrm{AF}$ & 16 & 23,49 & 25,29 & 2,41 & 20,57 & 25,95 & 20,95 & 25,56 \\
& $\mathrm{~F}$ & 16 & 24,47 & 24,40 & 1,58 & 22,48 & 26,34 & 23,06 & 25,99 \\
\hline
\end{tabular}

\subsubsection{Análise exploratória}

Nas Figuras 38, 39 e 40, pode-se visualizar o gráfico boxplot para a temperatura no interior da sala perante os diferentes dias, pontos de coleta e manejos da cortina, respectivamente.

Através da Figura 38 não se observa a presença de outliers para ambos os dias estudados, porém observa-se um desnivelamento dos dados e dispersões bem similares entre os boxplots.

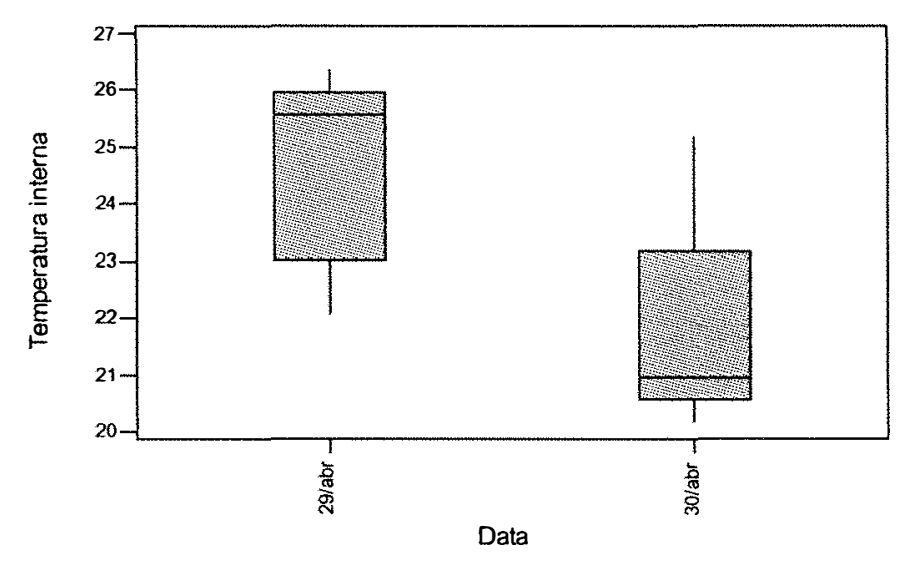

Figura 38- Gráfico boxplot comparativo para a temperatura interna em função dos diferentes dias de coleta 
Através da Figura 39, não se observa a presença de outliers para ambos os pontos de coleta estudados, porém observa-se um desnivelamento dos dados e dispersões levemente diferenciadas entre os boxplots.

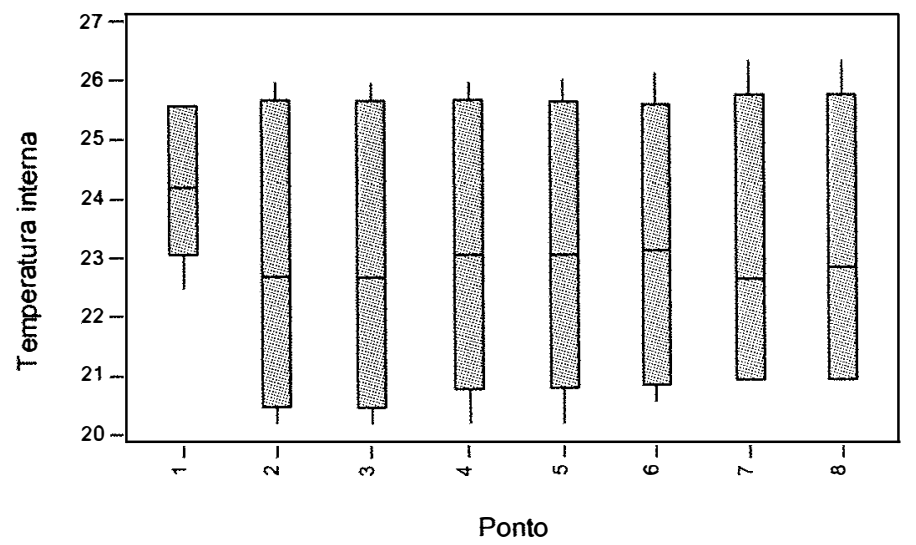

Figura 39 - Gráfico boxplot comparativo para a temperatura interna $\left({ }^{\circ} \mathrm{C}\right)$ em função dos diferentes pontos de coleta

Através da Figura 40, não se observa a presença de outliers para ambos os pontos de coleta estudados, porém observa-se um acentuado desnivelamento dos dados e dispersões diferenciadas entre os boxplots.

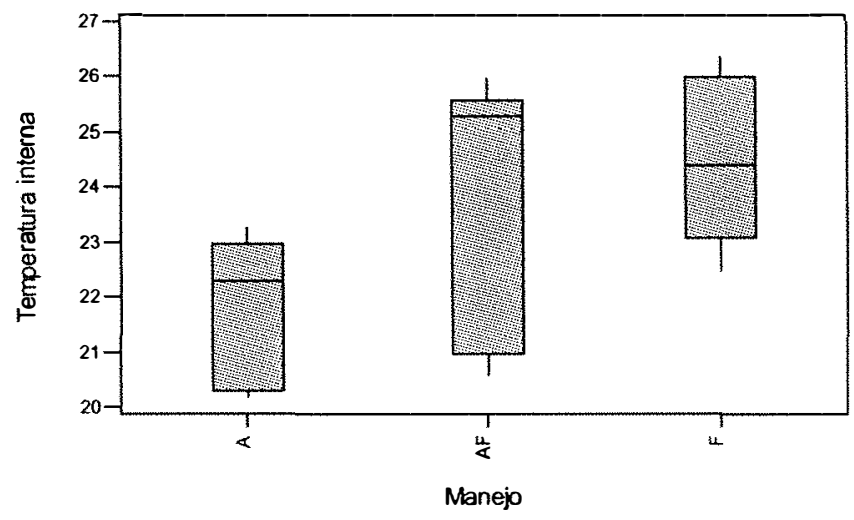

Figura 40 - Gráfico boxplot comparativo para a temperatura interna $\left({ }^{\circ} \mathrm{C}\right)$ em função dos diferentes manejos da cortina 
Através da Figura 41, pode-se observar que a média de temperatura encontrada no ponto 1 de coleta foi maior (em média $1,5^{\circ} \mathrm{C}$ ) que as médias obtidas nos outros pontos de coleta. Este fato pode ser explicado pelo posicionamento do ponto 1 que recebe ventilação de três aberturas simultaneamente: porta e as duas aberturas laterais.

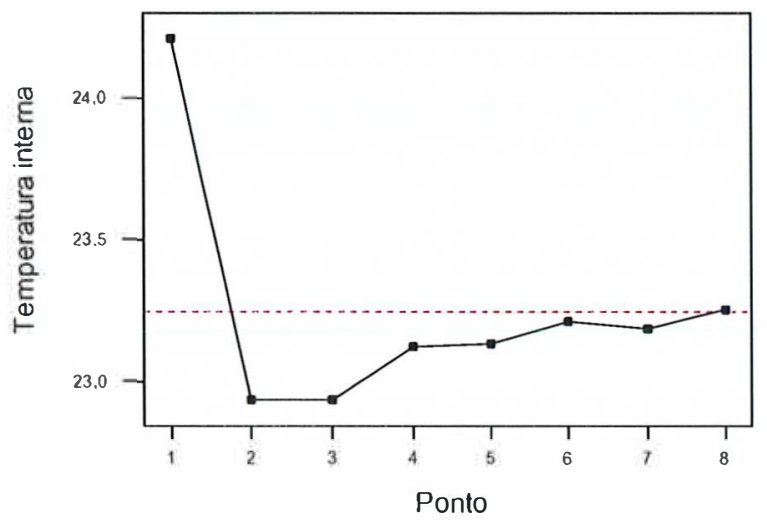

Figura 41 - Distribuição da temperatura $\left({ }^{\circ} \mathrm{C}\right)$ ao longo dos pontos da sala de maternidade

A Figura 42 permite analisar o comportamento da temperatura ao longo dos pontos para os diferentes manejos da cortina. Há uma tendência do manejo $(F)$ provocar maior estabilidade na temperatura ao longo dos pontos, ou seja, aparentemente, o manejo da cortina (F) minimiza a influência do ambiente externo no comportamento da temperatura ao longo da sala de maternidade. Nesta Figura observa-se que o ponto 1, não recebendo a ventilação das três aberturas anteriormente citadas, quando na condição $\mathrm{F}$, apresenta uma temperatura bem mais próxima dos demais pontos, o que não ocorre nas condições $\mathrm{AF}$ e $\mathrm{A}$. 


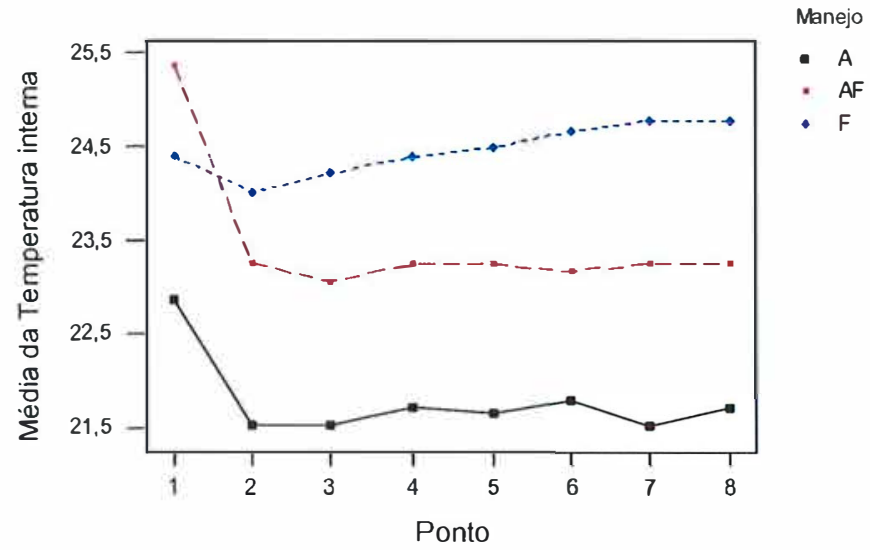

Figura 42 - Gráfico da interação dos fatores manejos da cortina e pontos de coleta para a temperatura interna $\left({ }^{\circ} \mathrm{C}\right)$

\subsubsection{Análise confirmatória}

Conforme pode ser observado na Tabela 26, houve interação significativa entre os fatores dia de coleta e os diferentes manejos da cortina $(p=0,028)$ e entre os fatores pontos de coleta e manejos da cortina $(\mathrm{p}=0,040)$. O fato de haver interação significativa conforme indicado pelo Teste $\mathrm{F}$ da Análise de Covariância da respectiva Tabela, mostra que o comportamento da temperatura ao longo dos pontos se diferencia para os diferentes manejos da cortina. Na Tabela 27, através do resultado do teste de Tukey comprova-se essa variação da temperatura ao longo dos diferentes pontos.

Esses resultados estão de acordo com os de Van Wagenberg et al. (2004), que trabalharam com medidas e simulações das condições climáticas dentro do que se denomina zona ocupada pelos animais (ZOA) em uma sala de maternidade suinícola, ventilada naturalmente e observaram variação da temperatura ambiente em função do posicionamento das baias ao longo da sala.

Experimentos realizados por Smith et al. (1999), trabalhando com o efeito da ventilação em instalações para produção de suínos observou que os animais confinados na instalação influenciaram a movimentação do ar devido as variações térmicas no ambiente. Os autores sugerem que os ocupantes de uma instalação ventilada naturalmente afetam a movimentação do ar por atuarem como defletores da vazão do ar, causando turbulência, e 
por gerarem calor, produzindo movimentações do ar por convecção. Em situações de baixa velocidade do ar a convecção induzida pelo calor dos animais pode ser um fator determinante nos modelos de distribuição do ar nas instalações.

Tabela 26. Resultado da Análise da Covariância para as médias da temperatura interna $\left({ }^{\circ} \mathrm{C}\right)$

\begin{tabular}{lccccc}
\hline Fonte & DF & SQ & QM & F & P \\
\hline UR $(\%)$ & 1 & 2,90 & 2,90 & 33,69 & 0,00 \\
Vento $(\mathrm{m} / \mathrm{s})$ & 1 & 0,21 & 0,21 & 2,39 & 0,15 \\
Data & 1 & 51,94 & 51,94 & 602,63 & 0,00 \\
Ponto & 7 & 4,15 & 0,59 & 6,88 & 0,00 \\
Manejo & 2 & 2,14 & 1,07 & 12,43 & 0,00 \\
Data*Ponto & 7 & 0,72 & 0,10 & 1,19 & 0,38 \\
Data*Manejo & 2 & 0,84 & 0,42 & 4,87 & 0,03 \\
Ponto*Manejo & 14 & 3,39 & 0,24 & 2,81 & 0,04 \\
Erro & 12 & 1,03 & 0,09 & & \\
Total & 47 & & & & \\
\hline
\end{tabular}

Analisando a Tabela 27, observa-se que apesar de não significativo, as maiores médias de temperatura foram obtidas nos manejos (F), com exceção do ponto 1 (AF) e 1 (A) que não se diferenciaram significativamente de todos os pontos com manejo (F). Isto se explica, já citado anteriormente, pelo fato do ponto 1 estar localizado junto às 3 aberturas da sala: porta e duas aberturas laterais sendo mais susceptível ao ambiente externo.

As temperaturas obtidas ao longo da sala estiveram acima do recomendado pela literatura, $21^{\circ} \mathrm{C}$. Porém muita controvérsia existe entre os valores de temperatura termoneutra recomendados para a nova genética presente na produção atual de suínos. Neste caso a recomendação está por volta de $26^{\circ} \mathrm{C}$, o que indicaria que as matrizes alojadas nesta sala estariam em conforto térmico nos três manejos da cortina avaliados. 
Tabela 27. Resultado do teste de Tukey para as médias de temperatura interna $\left({ }^{\circ} \mathrm{C}\right) \mathrm{da}$ combinação ponto-manejo

\begin{tabular}{|c|c|c|}
\hline Ponto-manejo & Média & $\mathbf{N}$ \\
\hline $1 \mathrm{AF}$ & $25,3650 \mathrm{a}$ & 2 \\
\hline $7 F$ & $24,7900 \mathrm{~b} a$ & 2 \\
\hline $8 \mathrm{~F}$ & $24,7900 \mathrm{~b} a$ & 2 \\
\hline $6 \mathrm{~F}$ & $24,6700 \mathrm{~b} \mathrm{a}$ & 2 \\
\hline $5 \mathrm{~F}$ & $24,5000 \mathrm{~b} \mathrm{a}$ & 2 \\
\hline $4 \mathrm{~F}$ & $24,4050 \mathrm{~b} a$ & 2 \\
\hline $1 \mathrm{~F}$ & $244000 \mathrm{~b} \mathrm{a}$ & 2 \\
\hline $3 F$ & $24,2150 \mathrm{~b} \mathrm{a}$ & 2 \\
\hline $2 \mathrm{~F}$ & $24,0200 \mathrm{~b} a$ & 2 \\
\hline $2 \mathrm{AF}$ & $23,2600 \mathrm{~b} a$ & 2 \\
\hline $4 \mathrm{AF}$ & $23,2550 \mathrm{~b} \mathrm{a}$ & 2 \\
\hline $7 \mathrm{AF}$ & $23,2550 \mathrm{~b} a$ & 2 \\
\hline $8 \mathrm{AF}$ & $23,2550 \mathrm{~b} \mathrm{a}$ & 2 \\
\hline $5 \mathrm{AF}$ & $23,2500 \mathrm{~b} \mathrm{a}$ & 2 \\
\hline $6 \mathrm{AF}$ & $23,1750 \mathrm{~b} a$ & 2 \\
\hline $3 \mathrm{AF}$ & $23,0650 \mathrm{~b} a$ & 2 \\
\hline $1 \mathrm{~A}$ & $22,8600 \mathrm{~b} a$ & 2 \\
\hline $6 \mathrm{~A}$ & $21,7850 \mathrm{~b}$ & 2 \\
\hline $4 \mathrm{~A}$ & $21,7150 \mathrm{~b}$ & 2 \\
\hline $8 \mathrm{~A}$ & $21,7150 \mathrm{~b}$ & 2 \\
\hline $5 \mathrm{~A}$ & $21,6500 \mathrm{~b}$ & 2 \\
\hline $3 \mathrm{~A}$ & $21,5250 \mathrm{~b}$ & 2 \\
\hline $2 \mathrm{~A}$ & $21,5250 \mathrm{~b}$ & 2 \\
\hline $7 \mathrm{~A}$ & $21,5200 \mathrm{~b}$ & 2 \\
\hline
\end{tabular}




\subsection{Análise dos dados de umidade relativa do interior da sala}

\subsubsection{Análise descritiva}

Nas Tabelas 28, 29 e 30, apresenta-se a análise descritiva para o fator dias de coleta, pontos de coleta e manejos da cortina, respectivamente.

Tabela 28. Resultado da análise descritiva dos dias de coleta para a umidade relativa interna da sala $(\%)$

\begin{tabular}{lccccccccc}
\hline Variável & Manejo & N & Média & Mediana & Desv.Padrão & Mín. & Máx. & Q1 & Q3 \\
\hline UR (\%) & 29/abr & 24,00 & 60,54 & 60,55 & 5,84 & 50,70 & 68,30 & 54,80 & 67,28 \\
& 30/abr & 24,00 & 61,85 & 62,50 & 6,07 & 52,20 & 70,90 & 56,52 & 67,25 \\
\hline
\end{tabular}

Tabela 29. Resultado da análise descritiva dos pontos de coleta para a umidade relativa interna da sala $(\%)$

\begin{tabular}{lccccccccc}
\hline Variável & Manejo & N & Média & Mediana & Desv.Padrão & Mín. & Máx. & Q1 & Q3 \\
\hline UR (\%) & 1 & 6,00 & 59,10 & 56,75 & 5,14 & 54,8 & 68,3 & 55,7 & 63,58 \\
& 2 & 6,00 & 61,88 & 63,00 & 5,44 & 55,1 & 67,7 & 56 & 66,57 \\
& 3 & 6,00 & 62,45 & 63,55 & 6,32 & 53,8 & 69,8 & 56,05 & 67,85 \\
& 4 & 6,00 & 63,13 & 64,80 & 6,25 & 54,7 & 69,8 & 56,43 & 68,22 \\
& 5 & 6,00 & 62,57 & 63,50 & 6,37 & 54,2 & 70 & 55,92 & 68,27 \\
& 6 & 6,00 & 62,23 & 62,75 & 6,81 & 54 & 70,9 & 55,05 & 68,42 \\
& 7 & 6,00 & 58,90 & 59,45 & 6,69 & 50,7 & 67,9 & 51,83 & 64,75 \\
& 8 & 6,00 & 59,32 & 59,85 & 6,12 & 52,3 & 67,3 & 52,45 & 64,9 \\
\hline
\end{tabular}


Tabela 30. Resultado da análise descritiva dos diferentes manejos da cortina para a umidade relativa interna da sala (\%)

\begin{tabular}{lccccccccc}
\hline Variável & Manejo & N & Média & Mediana & Desv.Padrão & Mín. & Máx. & Q1 & Q3 \\
\hline UR (\%) & A & 16,00 & 67,03 & 67,70 & 3,39 & 56,60 & 70,90 & 66,45 & 69,43 \\
& AF & 16,00 & 62,04 & 61,30 & 3,25 & 56,90 & 67,60 & 60,20 & 65,68 \\
& F & 16,00 & 54,52 & 54,75 & 1,86 & 50,70 & 57,00 & 52,83 & 56,23 \\
\hline
\end{tabular}

\subsubsection{Análise exploratória}

Nas Figuras 43 e 44, pode-se visualizar o gráfico boxplot para a umidade no interior da sala perante os diferentes pontos de coleta e manejos da cortina, respectivamente.

Através da Figura 43, não se observa a presença de outliers para ambos os dias estudados, porém observa-se um desnivelamento dos dados e dispersões bem similares entre os boxplots.

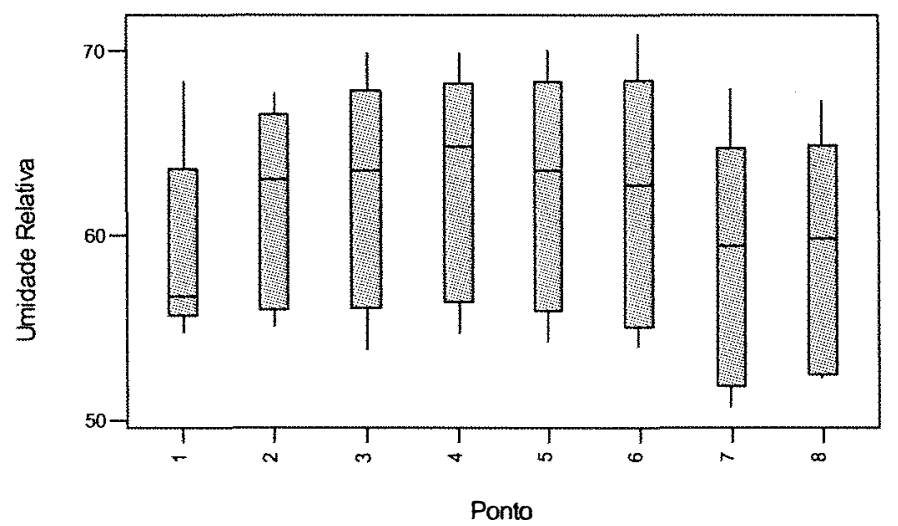

Figura 43 - Gráfico boxplot comparativo para a umidade relativa (\%) em função dos diferentes pontos de coleta

Através da Figura 43, observa-se a presença de outliers apenas para o manjo da cortina (A), um acentuado desnivelamento dos dados e dispersões diferenciadas entre os boxplots. 


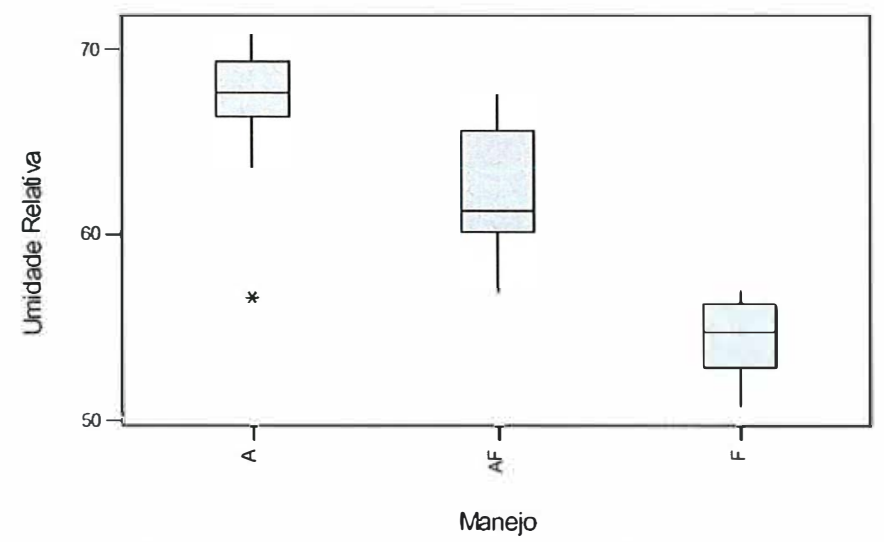

Figura 44 - Gráfico boxplot comparativo para a umidade relativa (\%) em função dos diferentes manejos da cortina

A Figura 45 permite analisar o comportamento da umidade relativa (UR) ao longo dos pontos para os diferentes manejos. Observa-se uma tendência do manejo da cortina (F) provocar maior estabilidade na UR ao longo da sala de maternidade.

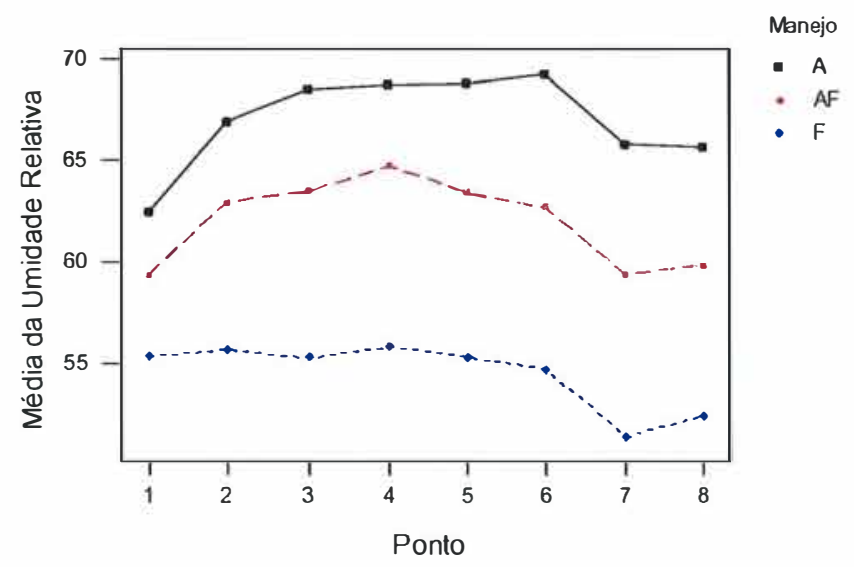

Figura 45 - Interação dos fatores manejos da cortina e pontos de coleta para a umidade relativa $(\%)$

\subsubsection{Análise confirmatória}

Conforme pode ser observado na Tabela 31, houve interação significativa entre os fatores pontos de coleta e manejos da cortina $(p=0,034)$. O fato de haver interação significativa conforme indicado pelo Teste $\mathrm{F}$ da Análise de Covariância da respectiva Tabela, mostra que o comportamento da UR ao longo dos pontos se diferencia para os 
diferentes manejos da cortina. Na Tabela 32, através do resultado do teste de Tukey comprova-se essa variação da UR ao longo dos diferentes pontos.

Tabela 31. Resultado da Análise da Covariância para as médias da UR (\%)

\begin{tabular}{lccccc}
\hline Fonte & GL & SQ & QM & F & P \\
\hline Temperatura $\left({ }^{\circ} \mathrm{C}\right)$ & 1 & 24,05 & 24,05 & 33,69 & 0,000 \\
Vento $(\mathrm{m} / \mathrm{s})$ & 1 & 1,54 & 1,54 & 2,15 & 0,168 \\
Data & 1 & 16,07 & 16,07 & 22,52 & 0,000 \\
Ponto & 7 & 88,33 & 12,62 & 17,68 & 0,000 \\
Manejo & 2 & 20,09 & 10,04 & 14,07 & 0,001 \\
Data*Ponto & 7 & 7,58 & 1,08 & 1,52 & 0,251 \\
Data*Manejo & 2 & 0,84 & 0,42 & 0,59 & 0,571 \\
Ponto*Manejo & 14 & 29,53 & 2,11 & 2,96 & 0,034 \\
Erro & 12 & 8,56 & 0,71 & & \\
Total & 47 & & & & \\
\hline
\end{tabular}


Tabela 32. Resultado do teste de Tukey para as médias de umidade relativa (\%) no interior da sala na combinação ponto-manejo

\begin{tabular}{lcc}
\hline Média & N & Ponto-manejo \\
\hline 69,250 a & 2 & $6 \mathrm{~A}$ \\
68,850 a & 2 & $5 \mathrm{~A}$ \\
68,750 a & 2 & $4 \mathrm{~A}$ \\
68,500 a & 2 & $3 \mathrm{~A}$ \\
66,950 b a & 2 & $2 \mathrm{~A}$ \\
65,800 b a c & 2 & $7 \mathrm{~A}$ \\
65,700 b a c & 2 & $8 \mathrm{~A}$ \\
64,800 b a c & 2 & $4 \mathrm{AF}$ \\
63,550 b d a c & 2 & $3 \mathrm{AF}$ \\
63,500 b d a c & 2 & $5 \mathrm{AF}$ \\
63,000 e b d a c & 2 & $2 \mathrm{AF}$ \\
62,750 e b d a c & 2 & $6 \mathrm{AF}$ \\
62,450 e b d a c & 2 & $1 \mathrm{~A}$ \\
59,850 e b d a c & 2 & $8 \mathrm{AF}$ \\
59,450 e b d a c & 2 & $1 \mathrm{AF}$ \\
59,450 e b d a c & 2 & $7 \mathrm{AF}$ \\
55,850 e b d c & 2 & $4 \mathrm{~F}$ \\
55,700 e b d c & 2 & $2 \mathrm{~F}$ \\
55,400 e b d c & 2 & $1 \mathrm{~F}$ \\
55,350 e b d c & 2 & $5 \mathrm{~F}$ \\
55,300 e b d c & 2 & $3 \mathrm{~F}$ \\
54,700 e d c & 2 & $6 \mathrm{~F}$ \\
52,400 e d & 2 & $8 \mathrm{~F}$ \\
51,450 e & 2 & $7 \mathrm{~F}$ \\
\hline
\end{tabular}

Analisando a Tabela 32, observa-se que a UR decai a medida que se fecham as cortinas. Isto ocorre, pois a temperatura aumenta quando se faz esse manejo, como era 
esperado. Em todos os manejos estudados e em todos os pontos avaliados a UR permaneceu dentro da faixa recomendada para matrizes e leitões: 50 a $75 \%$ (Veit \& Troutt, 1982).

Esses resultados encontrados em termos de variação da UR e da temperatura ao longo da sala de maternidade concordam com os obtidos por Boon (1978) e Jin \& Olgive (1992), que observaram que as variações de temperatura e UR no perfil horizontal e vertical das instalações são função dos tipos de aberturas e configurações da ventilação.

\subsection{Análise dos dados da temperatura de pele das matrizes e leitões}

\subsubsection{Análise descritiva}

Nas Tabelas 33 e 34, apresenta-se a análise descritiva para a combinação baiamanejo na variável temperatura de pele dos leitões e matrizes, respectivamente. 
Tabela 33. Resultado da análise descritiva da interação baia-manejo para a temperatura de pele dos leitões $\left({ }^{\circ} \mathrm{C}\right)$

\begin{tabular}{lccccccccc}
\hline Variável & Dia & N & Média & Mediana & Desv.Padr. & Mín. & Máx. & Q1 & Q3 \\
\hline Temperatura & 1A & 4 & 34,558 & 34,115 & 1,749 & 33 & 37 & 33,168 & 36,39 \\
De pele & 1A/F & 4 & 33,113 & 32,89 & 1,134 & 32 & 34,67 & 32,168 & 34,28 \\
$\left({ }^{\circ} \mathrm{C}\right)$ & 1F & 4 & 33,998 & 34,165 & 0,471 & 33,33 & 34,33 & 33,498 & 34,33 \\
& 2A & 4 & 35,002 & 34,835 & 0,471 & 34,67 & 35,67 & 34,67 & 35,503 \\
& 2A/F & 4 & 35,998 & 35,665 & 0,943 & 35,33 & 37,33 & 35,33 & 36,998 \\
& 2F & 4 & 35,78 & 35,725 & 0,954 & 34,67 & 37 & 34,92 & 36,695 \\
& 3A & 4 & 32,89 & 32,945 & 0,156 & 32,67 & 33 & 32,725 & 33 \\
& 3A/F & 4 & 36,223 & 36,445 & 0,632 & 35,33 & 36,67 & 35,552 & 36,67 \\
& 3F & 4 & 35,33 & 35,33 & 0,816 & 34,33 & 36,33 & 34,58 & 36,08 \\
& 4A & 4 & 32 & 32,165 & 0,979 & 30,67 & 33 & 31,002 & 32,833 \\
& 4A/F & 4 & 34,668 & 34,67 & 1,09 & 33,33 & 36 & 33,665 & 35,668 \\
& 4F & 4 & 34,112 & 34,39 & 1,029 & 32,67 & 35 & 33,03 & 34,918 \\
& 5A & 4 & 32,78 & 32,725 & 0,156 & 32,67 & 33 & 32,67 & 32,945 \\
& 5A/F & 4 & 34,778 & 34,89 & 0,565 & 34 & 35,33 & 34,195 & 35,248 \\
& 5F & 4 & 34 & 33,5 & 1,908 & 32,33 & 36,67 & 32,498 & 36,003 \\
& $6 \mathrm{~A}$ & 4 & 33,443 & 33,72 & 0,787 & 32,33 & 34 & 32,608 & 34 \\
& $6 \mathrm{~A} / \mathrm{F}$ & 4 & 33,558 & 33,445 & 0,832 & 32,67 & 34,67 & 32,835 & 34,393 \\
6F & 4 & 34,558 & 34,78 & 0,627 & 33,67 & 35 & 33,892 & 35 \\
\hline
\end{tabular}


Tabela 34. Resultado da análise descritiva da interação baia-manejo para a temperatura de pele das matrizes $\left({ }^{\circ} \mathrm{C}\right)$

\begin{tabular}{lccccccccc}
\hline Variável & \multicolumn{1}{c}{ Baia-manej } & Média & Mediana & Desv.Padr. & Mín. Max. & Q1 & Q3 \\
\hline Temperatura & $1 \mathrm{~A}$ & 4 & 32 & 31,75 & 0,707 & 31,5 & 33 & 31,5 & 32,75 \\
da matriz & $1 \mathrm{~A} / \mathrm{F}$ & 4 & 33,333 & 33,415 & 0,624 & 32,5 & 34 & 32,70 & 33,87 \\
$\left({ }^{\circ} \mathrm{C}\right)$ & $1 \mathrm{~F}$ & 4 & 33,832 & 33,915 & 0,236 & 33,5 & 34 & 33,58 & 34,00 \\
& $2 \mathrm{~A}$ & 4 & 33,168 & 33,335 & 0,85 & 32 & 34 & 32,29 & 33,87 \\
& 2A/F & 4 & 33,668 & 33,335 & 0,943 & 33 & 35 & 33 & 34,66 \\
& 2F & 4 & 34 & 33,75 & 0,707 & 33,5 & 35 & 33,5 & 34,75 \\
& 3A & 4 & 32,5 & 32,75 & 1,08 & 31 & 33,5 & 31,37 & 33,37 \\
& $3 \mathrm{~A} / \mathrm{F}$ & 4 & 34,168 & 34,085 & 0,624 & 33,5 & 35 & 33,62 & 34,79 \\
& 3F & 4 & 34,668 & 34,585 & 0,236 & 34,5 & 35 & 34,5 & 34,91 \\
& $4 \mathrm{~A}$ & 4 & 31,832 & 31,665 & 0,85 & 31 & 33 & 31,12 & 32,70 \\
& $4 \mathrm{~A} / \mathrm{F}$ & 4 & 34,668 & 34,835 & 0,85 & 33,5 & 35,5 & 33,79 & 35,37 \\
& $4 \mathrm{~F}$ & 4 & 35,168 & 35,335 & 0,471 & 34,5 & 35,5 & 34,66 & 35,50 \\
& $5 \mathrm{~A}$ & 4 & 30,832 & 30,665 & 0,471 & 30,5 & 31,5 & 30,5 & 31,33 \\
& $5 \mathrm{~A} / \mathrm{F}$ & 4 & 33,668 & 33,585 & 0,236 & 33,5 & 34 & 33,5 & 33,91 \\
& $5 \mathrm{~F}$ & 4 & 34,168 & 33,835 & 0,943 & 33,5 & 35,5 & 33,5 & 35,16 \\
& $6 \mathrm{~A}$ & 4 & 30,832 & 30,665 & 0,471 & 30,5 & 31,5 & 30,5 & 31,33 \\
& $6 \mathrm{~A} / \mathrm{F}$ & 4 & 32,668 & 32,585 & 0,236 & 32,5 & 33 & 32,5 & 32,91 \\
$6 \mathrm{~F}$ & 4 & 34,332 & 34,165 & 0,471 & 34 & 35 & 34 & 34,83 \\
\hline
\end{tabular}

\subsubsection{Análise exploratória}

Através das Figuras 46 e 47, observa-se um perfil de não paralelismo entre os níveis de manejo da cortina para as diferentes baias, ou seja, de forma geral, observa-se que as linhas formadas pelos diferentes manejos são cruzadas. Essa característica é padrão para o caso de haver interação entre fatores manejo e posição da baia para as médias de 
temperatura de pele dos leitões e das matrizes. Como, aparentemente, houve interação cabe analisar a combinação dos níveis dos fatores baia e manejo.

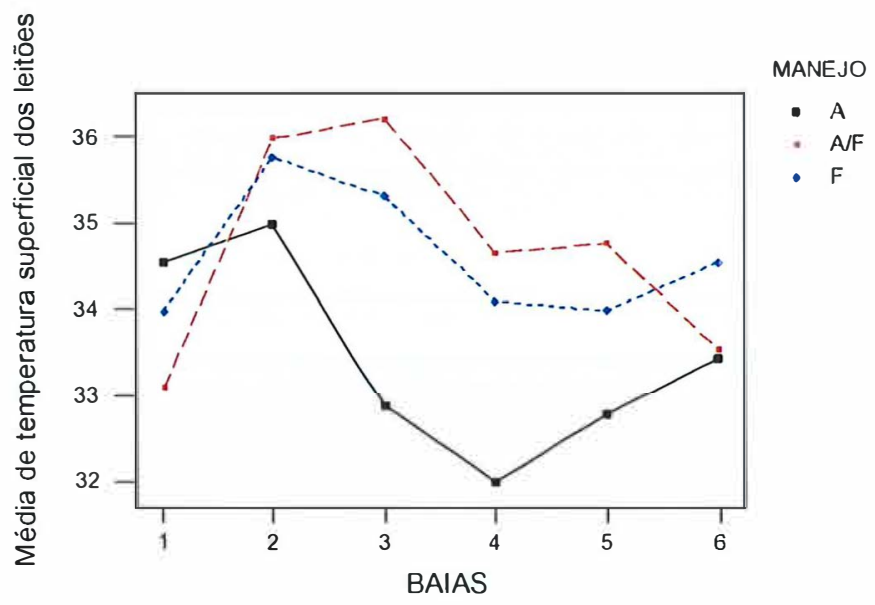

Figura 46 - Interação entre baias e manejos para as médias de temperatura de pele dos leitões $\left({ }^{\circ} \mathrm{C}\right)$

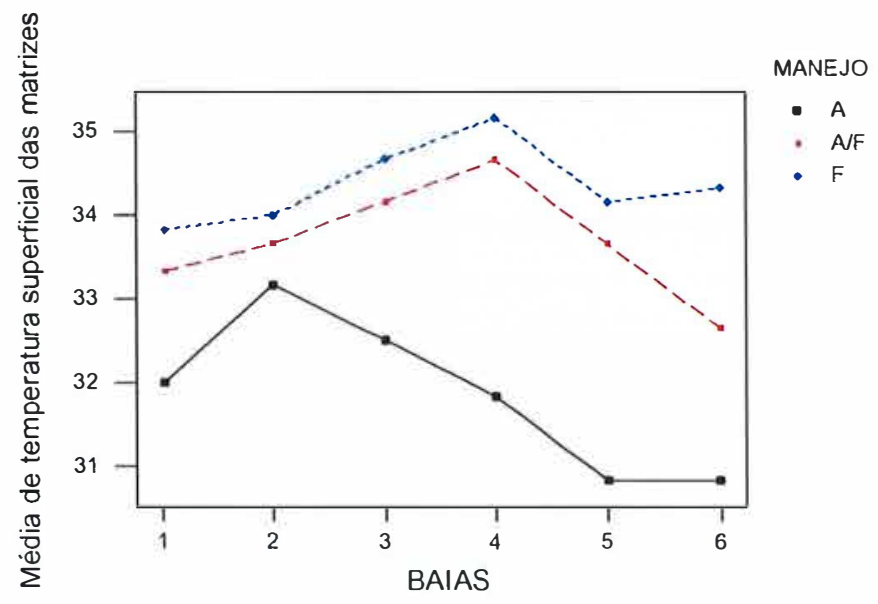

Figura 47 - Interação entre baias e manejos para as médias de temperatura de pele das matrizes $\left({ }^{\circ} \mathrm{C}\right)$

Tanto na Figura 48 como na Figura 49, onde se apresentam os gráficos boxplots para as combinações baia-manejo para a temperatura de pele dos leitões e das porcas, 
respectivamente, não se observa a presença de outliers para as diferentes combinações avaliadas. Os nivelamentos dos boxplots são diferentes, o que demonstra uma diferenciação da magnitude da temperatura de pele dos animais para os níveis combinados. Observa-se, também, variações das dispersões entre os boxplots.

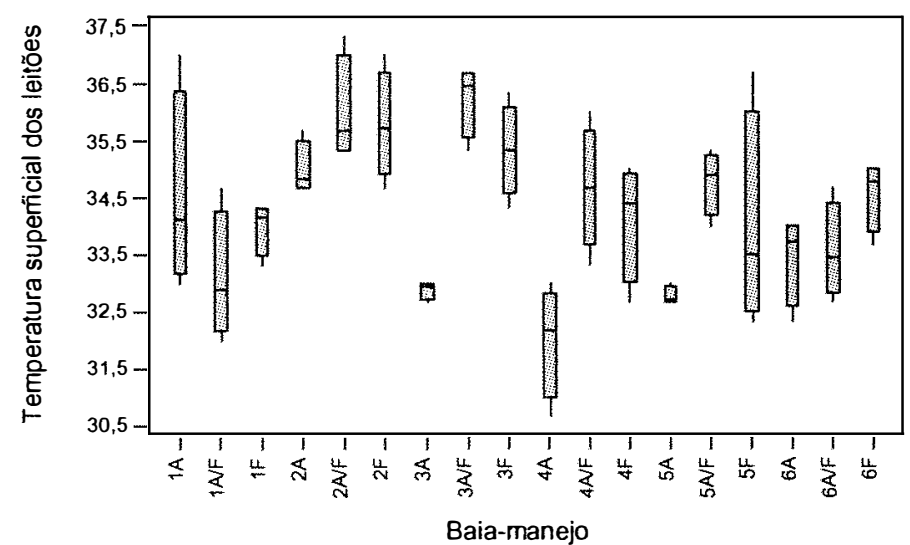

Figura 48 - Gráfico boxplot comparativo para a temperatura de pele dos leitões $\left({ }^{\circ} \mathrm{C}\right)$ perante as diferentes combinações baia-manejo

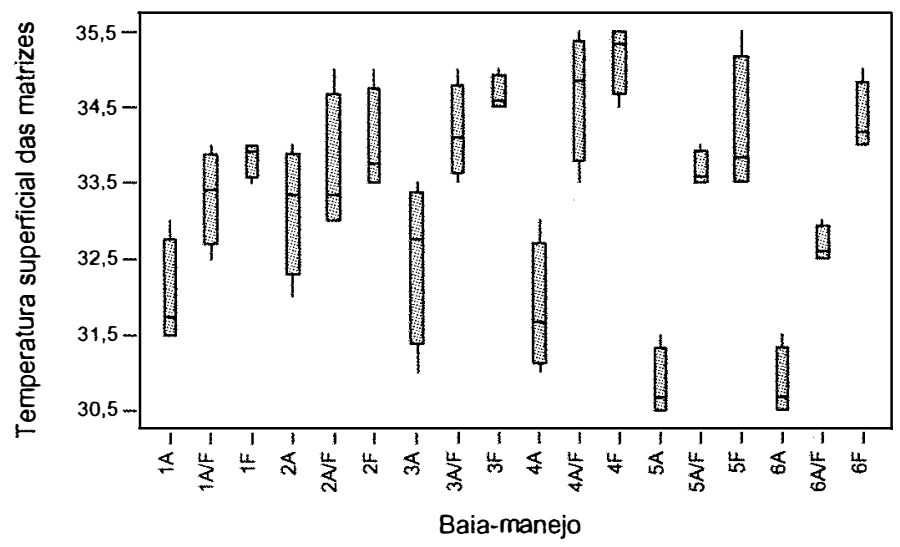

Figura 49 - Gráfico boxplot comparativo para a temperatura de pele das matrizes $\left({ }^{\circ} \mathrm{C}\right)$ perante as diferentes combinações baia-manejo 


\subsubsection{Análise confirmatória}

Nas Tabelas 35 e 36, apresenta-se o resultado da Análise da Covariância para as médias da temperatura de pele dos leitões e das matrizes, respectivamente. Tanto para as médias de temperatura de pele das matrizes como dos leitões, comprovou-se haver interação significativa do fator baia com o fator manejo da cortina, conforme demonstrado na Figura 46. Isso mostra, que a variação na temperatura de pele dos animais foi afetada pelo manejo e pela locação na baia, conjuntamente.

Nas Tabelas 37 e 38, apresenta-se o resultado do teste de Tukey para as médias da temperatura de pele dos leitões e das matrizes, respectivamente. Tanto para os leitões como para as matrizes, observa-se uma grande e significativa variação em função da condição do manejo da cortina adotado e da localização da baia, o que pode ser melhor visualizado na Figura 50. Esses resultados concordam com pesquisas realizadas por Carvalho et al. (2004), Tolon (2002) e Souza (2002), que encontraram diferenças significativas na temperatura de pele de suínos na fase de terminação, lactação e gestação, respectivamente, quando submetidos a diferentes condições de ventilação e resfriamento evaporativo.

Observa-se, também, que em média, as temperaturas superficiais dos leitões são maiores que a das matrizes, devido ao intenso metabolismo dos animais jovens, acarretando em maiores perdas de calor de seus corpos. Esse resultado está de acordo com Blair et al. (1976), que afirmaram que o aumento da taxa metabólica do leitão se deve ao fato do animal ter que usar grande parte de sua produção de energia para se manter aquecido.

Para as matrizes, em média, as condições de manejo (F) e (AF) foram as que apresentaram os maiores valores de temperatura de pele, como era esperado. O mesmo não ocorreu com os leitões, que apresentam exigências térmicas totalmente distintas das matrizes.

Conforme Lee \& Phillips (1948), os suínos são os mais sensíveis a altas temperaturas dentre os animais domésticos e com o resultado da análise anterior sobre a heterogeneidade de distribuição de temperatura e umidade relativa ao longo da sala, 
explica-se o motivo de haver influência das posições das baias nas temperaturas de pele dos animais. Explica-se, também, a variabilidade existente nas temperaturas médias de pele dos animais, nas diferentes possíveis reações individuais que os animais possam apresentar perante as condições térmicas impostas pelo ambiente.

Tabela 35. Resultado da Análise da Covariância para as médias da temperatura de pele dos leitões $\left({ }^{\circ} \mathrm{C}\right)$

\begin{tabular}{lccccc}
\hline Fonte & GL & SQ & QM & F & P \\
\hline Vento-Baia $(\mathrm{m} / \mathrm{s})$ & 1 & 1,0057 & 1,0057 & 1,07 & 0,306 \\
Vento externo $(\mathrm{m} / \mathrm{s})$ & 1 & 1,5979 & 1,5979 & 1,7 & 0,199 \\
Temperatura $\left({ }^{\circ} \mathrm{C}\right)$ & 1 & 0,1235 & 0,1235 & 0,13 & 0,719 \\
UR $(\%)$ & 1 & 0,446 & 0,446 & 0,47 & 0,494 \\
Baia & 5 & 33,5692 & 6,7138 & 7,13 & 0 \\
Manejo & 2 & 1,5233 & 0,7617 & 0,81 & 0,451 \\
Baia*Manejo & 10 & 32,0769 & 3,2077 & 3,41 & 0,002 \\
Erro & 50 & 47,077 & 0,9415 & & \\
Total & 71 & & & & \\
\hline
\end{tabular}

Tabela 36. Resultado da Análise da Covariância para as médias da temperatura de pele das matrizes $\left({ }^{\circ} \mathrm{C}\right)$

\begin{tabular}{lccccc}
\hline Fonte & GL & SQ & QM & F & P \\
\hline Vento-baia $(\mathrm{m} / \mathrm{s})$ & 1 & 0,0178 & 0,0178 & 0,04 & 0,836 \\
Vento externo $(\mathrm{m} / \mathrm{s})$ & 1 & 0,0886 & 0,0886 & 0,22 & 0,644 \\
Temperatura $\left({ }^{\circ} \mathrm{C}\right)$ & 1 & 1,3991 & 1,3991 & 3,41 & 0,071 \\
UR $(\%)$ & 1 & 0,0078 & 0,0078 & 0,02 & 0,891 \\
Baia & 5 & 15,7711 & 3,1542 & 7,69 & 0,000 \\
Manejo & 2 & 10,4278 & 5,2139 & 12,71 & 0,000 \\
Baia*Manejo & 10 & 15,1849 & 1,5185 & 3,7 & 0,001 \\
Erro & 50 & 20,506 & 0,4101 & & \\
Total & 71 & & & & \\
\hline
\end{tabular}


Tabela 37. Resultado do teste de Tukey para a interação das médias baia-manejo da temperatura de pele dos leitões $\left({ }^{\circ} \mathrm{C}\right)$

\begin{tabular}{cll}
\hline Baia-manejo Média & N \\
\hline 3AF & 36,2225 a & 4 \\
2AF & 35,9975 b a & 4 \\
2F & 35,7800 b a c & 4 \\
3F & 35,3300 b d a c & 4 \\
2A & 35,0025 e b d a c & 4 \\
5AF & 34,7775 e b d a c & 4 \\
$4 \mathrm{AF}$ & 34,6675 e b d a c & 4 \\
1A & 34,5575 e b d a c & 4 \\
6F & 34,5575 e b d a c & 4 \\
$4 \mathrm{~F}$ & 34,1125 e b d a c f & 4 \\
5F & 34,0000 e b d a c f & 4 \\
1F & 33,9975 e b d a c f & 4 \\
$6 \mathrm{AF}$ & 33,5575 e b d c f & 4 \\
6A & 33,4425 e d c f & 4 \\
1AF & 33,1125 e d f & 4 \\
3A & 32,8900 e d f & 4 \\
$5 \mathrm{~A}$ & 32,7800 e f & 4 \\
\hline
\end{tabular}


Tabela 38. Resultado do teste de Tukey para a temperatura de pele das matrizes $\left({ }^{\circ} \mathrm{C}\right)$

\begin{tabular}{cll}
\hline Baia-Manejo Média & N \\
\hline 4F & $35,1675 \mathrm{a}$ & 4 \\
3F & $34,6675 \mathrm{~b} \mathrm{a}$ & 4 \\
4AF & $34,6675 \mathrm{~b} \mathrm{a}$ & 4 \\
6F & $34,3325 \mathrm{~b} \mathrm{a} \mathrm{c}$ & 4 \\
5F & $34,1675 \mathrm{~b} \mathrm{~d} \mathrm{a} \mathrm{c}$ & 4 \\
3AF & $34,1675 \mathrm{~b} \mathrm{~d} \mathrm{a} \mathrm{c}$ & 4 \\
2F & $34,0000 \mathrm{~b} \mathrm{~d} \mathrm{a} \mathrm{c}$ & 4 \\
1F & $33,8325 \mathrm{~b} \mathrm{~d} \mathrm{a} \mathrm{c}$ & 4 \\
2AF & $33,6675 \mathrm{e} \mathrm{b} \mathrm{d} \mathrm{a}$ & 4 \\
5AF & $33,6675 \mathrm{e} \mathrm{b} \mathrm{d} \mathrm{a}$ & 4 \\
1 AF & $33,3325 \mathrm{e} \mathrm{b} \mathrm{d} \mathrm{f}$ & 4 \\
2A & 33,1675 e b d f & 4 \\
$6 \mathrm{AF}$ & $32,6675 \mathrm{e} \mathrm{d} \mathrm{f} \mathrm{c}$ & 4 \\
1A & $32,0000 \mathrm{e} \mathrm{g} \mathrm{f}$ & 4 \\
$4 \mathrm{~A}$ & $31,8325 \mathrm{~g} \mathrm{f}$ & 4 \\
$5 \mathrm{~A}$ & $30,8325 \mathrm{~g}$ & 4 \\
$6 \mathrm{~A}$ & $30,8325 \mathrm{~g}$ & 4 \\
\hline
\end{tabular}

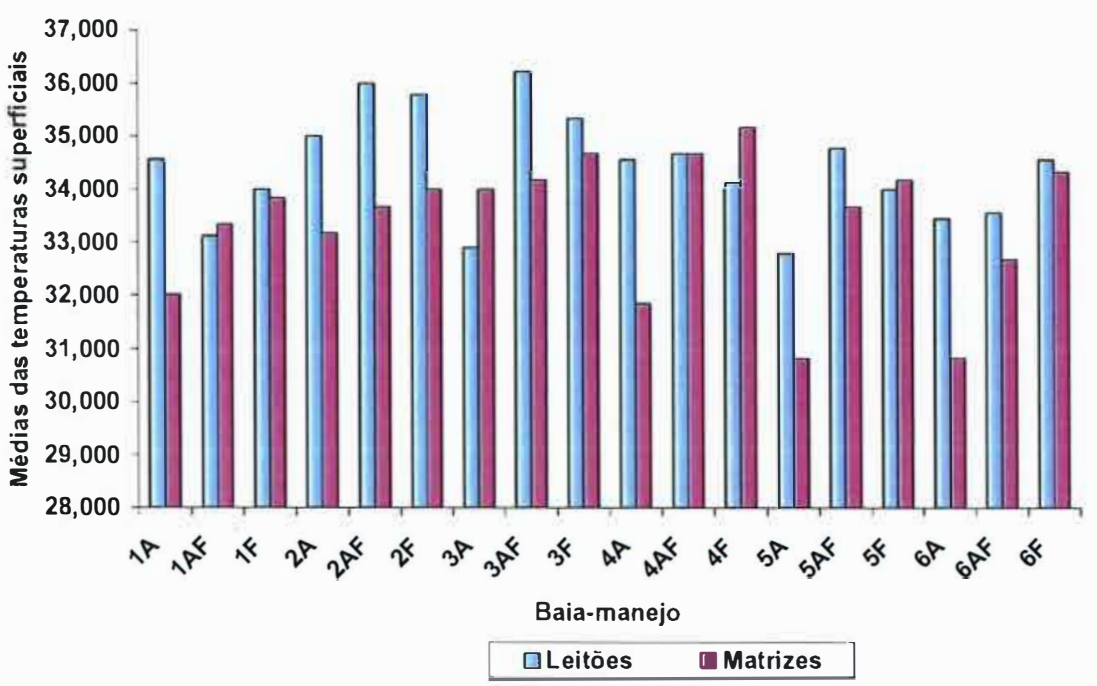

Figura 50 - Interações baia-manejo na temperatura de pele dos leitões e das matrizes $\left({ }^{\circ} \mathrm{C}\right)$ 


\section{CONCLUSÕES GERAIS}

O manejo das aberturas para a entrada de ar em salas de maternidade para produção intensiva de suínos, influencia significativamente o ambiente térmico resultante afetando a distribuição da temperatura, umidade relativa e velocidade do vento no interior da sala de maternidade.

O manejo da ventilação natural afeta a distribuição da temperatura de superficie dos pisos dos escamoteadores aquecidos por pisos térmicos e lâmpadas incandescentes. A magnitude deste efeito é influenciada pela condição externa de temperatura, pela condição de manejo da cortina e pelo tipo de aquecimento.

Os escamoteadores aquecidos por pisos térmicos mostraram uma distribuição de temperatura superficial mais homogênea independentemente do manejo da cortina adotado.

A temperatura de pele das matrizes foi afetada significativamente pela condição de manejo da cortina adotada. Já para os leitões, esse efeito não foi observado.

Os sistemas de aquecimento para leitões na maternidade são altamente afetados pela ventilação natural, proveniente dos diferentes manejos da cortina, sugerindo a necessidade de um controle conjugado de ventilação natural com o sistema de aquecimento adotado. 


\section{REFERÊNCIAS BIBLIOGRÁFICAS}

ABREU, P.G.; ABREU, V.M.N. Maximização dos sistemas de ventilação na avicultura. Concórdia: EMBRAPA, CNPSA, 2005. 15p.

\section{ANUÁRIO PORK WORLD - 2003, n.17, p.92, 2004.}

AMERICAN SOCIETY OF HEATING AND REFRIGERATION AND AIR (ASHRAE) - Conditioning Engineers. Handbook of fundamentals. Atlanta, 1985.

\section{AMERICAN SOCIETY OF HEATING AND REFRIGERATION AND AIR} (ASHRAE) - Conditioning Engineers. Handbook of fundamentals. Atlanta, 1997.

BÄCKSTRÖM, L.; CURTIS, S.E. Housing and environmental influences on production. In: LEMAN, A.D. Diseases of swine. Ames: Iowa State University Press, 1981. p.737-753.

BAÊTA, F.C.; SOUZA, C.F. Ambiência em edificações rurais: conforto animal. Viçosa: UFV, 1997. 246p.

BLAIR, L.A.; FJELD, H., STROKAPPE, J.A.; REDDSON, A. Swine production and management. Canada Agriculture, v.1442, p. 1-20, 1976.

BOON, C.R. Airflow patterns and temperature distribution in an experimental piggery. Journal of Agricultural Engineering Research, v.23, p.129-139, 1978. 
BRUCE, J.M.; CLARCK, J.J. Models of heat production and critical temperature for growing pigs. Animal Production. v.28, p.353-369, 1979.

BUKVAJ, J. Cattle organism and rearing environment in large-capacity housing. Praha, 1986. 79p. Tesi’s (PhD.) - VSZ Praha.

CARVALHO, L.E.; OLIVEIRA, S.M.P.; TURCO, S.H.N. R. Utilização da nebulização e ventilação forçada sobre o desempenho e a temperatura da pele de suínos na fase de terminação. Revista Brasileira de Zootecnia. v.33, n.6, p.1486-1491, 2004.

CHIKAMUNE, T. Effects of environmental temperature on thermoregulatory responses and oxygen consumption in swamp buffaloes and holstein cattle. Buffalo Journal, v.2, p.151-160, 1986.

CHOINIERE, Y. Wind induced natural ventilation of low-rise buildings for livestock housing by the pressure difference method and concentration decay method. Ontario, 1991. 97p. Tesi's (PhD.) - Alfred College of Agriculture and Food Technology.

CLOSE, W.H.; MOUNT, L.E.; START, I.B. The influence of environmental temperature and plane of nutrition on heat looses from groups of growing pigs. Animal Production, v.13, p.285-294, 1971.

COMBERG, G. Einige Bemerkungen, zum wärmedarf der Ferkel. Schweinezucht Schweinemast, v.14, n.1, p.2-3, 1966.

COSSINS, A.R.; BOWLER, K. Temperature biology of animals. London: Chapman and Hall, 1987. 325p.

DIVIDICH, J.L.; RINALDO, D. Effects de l'environement thérmique sur les performance du porc en croissance. Journée d la Recherche Porcine en France, n.21, p.219-230, 1989. 
FROTA, A.B.; SHIFFER, S.R. Manual de conforto térmico. 2. ed. São Paulo: Studio Nobel, 1995. 243p.

GERKEN, M.; BAROW, U.; SNELL, H. Methodical investigations into thermoregulation in suckler cows under field conditions. ANNUAL MEETING OF THE EUROPEAN ASSOCIATION OF ANIMAL PRODUCTION, 49., Warsaw, 1998. Abstracts. Warsaw: 1998. p.179.

HARRAL, B.B.; BOON, C.R. Comparison of predicted and measured air flow patterns in a mechanically ventilated livestock building without animals. Journal of Agricultural Engineering Research, v.66, p.221-228, 1997.

HENKEN, A.M.; BRANDSMA, H.A.; VAN DER HEL, W.; WESTERGEN, M.W.A. Circadian rhythm in head production of limit-fed growing pigs of several bredds keept at and below thermal neutrality. Journal of Animal Science, v.71, p.14341440, 1993.

HOLMES, C.W.; CLOSE, W.H. Influence of climatics variables on energy metabolism and associetad aspects of productivity in the pigs. NUTRITION AND CLIMATIC ENVIRONMENT, BUTTERWORTHS, 1977. Proceedings. Butterworths, 1977. p.51-73.

INGRAM, D.L. The effect of humidity on temperature regulation and cutaneous water loss in young pig. Research Veterinary Science. v.6, p.9-17, 1965.

JIN, Y.; OGILVIE, J.R. Airflow characteristics in the floor region of a slot ventilated room (isothermal). Transaction of the ASAE, v.3, n.2, p.695-702, 1992.

KELLY, K.W. Environmental effects on the immune system of pigs. Pig News and Information, v.3, n.4, p.359-369, 1982. 
KNÍZKOVÁ, I.; KUNE, P.; KOUBKOVÁ, M.; FlUSSER, J.; DOLEZAL, O. Evaluation of naturally ventiled dairy barn management by a thermographic method. Livestock Production Science, v.77, p.349-353, 2002.

LEE, D.H.K.; PHILLIPS, R.W. Assesment of the adaptability of livestock to climatic stress. Journal of Animal Science, v.7, n.4, p.391-425, 1948.

MENESES, J.F.S. Ventilação natural controlada automaticamente em instalações para suínos. Lisboa, 1985. 254p. Tese (Doutorado) - I.S.A. Lisboa.

MINITAB RELEASE VERSION 12.1 - STATISTICAL SOFTWARE FOR Windows. Minitab Inc., 2002.

MIRAGLIOTTA, M.Y.; NAAS, I.A.; MANZIONE, R.L.; NASCIMENTO, F.F. Spatial analysis of stress conditions inside broiler commercial housing. INTERNATIONAL SYMPOSIUM OF THE CIGR- NEW TRENDS IN FARM BUILDINGS, Évora, 2004. Proceedings. Évora: Universidade de Évora, 2004. p. 1-5.

MITCHELL, M.A. Effects of air velocity on convective and radiant heat transfer from domestic fowls at environmental temperature of $20 \mathrm{C}$ and $30 \mathrm{C}$. Britihs Poultry Science, v.6, p.413-423, 1985.

MORRISON, S.R.; GIVENS, R.L.; HEITMAN JR.H. Effects of air movement on swine at high temperature. International Journal of Biometeorology, v.20, n.4, p.337-343, 1976.

MORRISON, S.R.; HEITMAN JR., H.; BOND, T.E. Effect of humidity on swine at temperatures above optimum. International Journal of Biometeorology, v.13, n.2, p.135-139, 1969. 
MORSING, S.; IKEGUCHI, A.; BENNETSEN, J.C.; STROM, J.S.; RAVN, P.; OKUSHIMA, L. Wind induced airflow patterns in a naturally ventilated barn. INTERNATIONAL CONFERENCE IN SWINE HOUSING, 1., Ames, 2000. Proceedings. Ames: ASAE, 2000. p.18-25.

MOUNT, L.E. The assesment of thermal environment. London: Arnold, 1979. 333p.

MOURA, D.J. Ventilação na suinocultura. In: SILVA, I.J.O. Ambiência e qualidade na produção industrial de suínos. Piracicaba: FEALQ. 1999. p.149-179.

NÄÄS, I.A.; RODRIGUES, E.H.V. Qualidade do ambiente para a produção de suínos na gestação e maternidade. In SILVA, I.J.O. Ambiência e qualidade na produção industrial de suínos. Piracicaba: FEALQ. 1999. p.112-130.

NECOECHEA, A.R. Doenças e meio ambiente. Suinocultura Industrial, v.8, n.8, p.13-26, 1986.

NIENABER, J.A.; HAHN, G.L. Environmental temperatures influences on heat production of ad-lib-fed, nursery and growing-finishing swine. INTERNATIONAL LIVESTOCK ENVIRONMENT SYMPOSIUM, 3., Toronto, 1988. Proceedings. Toronto: ASAE, 1988. p.73-78.

OLSON, D.P. The effects of cold exposure on neonatal calves. Bovine Proceedings, v.16, p.64-68, 1984.

PANDORFI, H. Avaliação do comportamento de leitões em diferentes sistemas de aquecimento por meio da análise de imagem e identificação eletrônica. Piracicaba, 2002. 89p. Dissertação (Mestrado) - Escola Superior de Agricultura "Luiz de Queiroz", Universidade de São Paulo. 
PERDOMO, C.C.; SOBESTIANSKY, J.; OLIVEIRA, P.V.A.; OLIVEIRA, J.A. Efeito de diferentes sistemas de aquecimento no desempenho de leitões. Concórdia: EMBRAPA, CNPSA, 1987.3p. (Comunicado Técnico, 122 ).

PERDOMO, L.C. Avaliação de sistemas de ventilação sobre o condicionamento ambiental e o desempenho de suínos fa fase de maternidade. Pelotas, 1995. 86p. Tese (Doutorado) - Universidade Federal de Pelotas.

RANDALL, J.M. The prediction of airflow patterns in livestock buildings. Journal of Agricultural Engineering Research, v.20, n.2, p.199-215, 1975.

REIS, R.L.P.S. Efeito comporativo da lâmina d'água na terminação de suínos. Campinas, 1995. 112p. Dissertação (Mestrado) - Faculdade de Engenharia aAgrícola, Universidade Estadual de Campinas.

SALLVIK, K. ; PEDERSEN, S. CIGR Handbook of agricultural engineering - Animal production \& aquacultural engineering. BARTALI, E.H. (Ed). Animal heat and moisture production. Iowa: CIGR, 1995. v.2, p.41-53.

SCOTT, N.R.; DESHAZER, J.A.; ROLLER, W.L. Effects de thermal and gases environment on livestock. In: HELLICKSON, M. ; WALKER, J.N. Ventilation of agricultural structural. St. Joseph: ASAE, 1983. p.121-165.

SIMMONS, J.R. Keeping piglets warm. Veterinary Record, v.98, n.19, p.381-382, 1976.

SMITH, J.H.; BOON, C.R.; WEBSTER, A.J.F.; WATES, C.M. Measuriments of the effect of animals on air flow in an experimental piggery. Journal of Agricultural Engineering Research, v.72, n.2, p.105-112, 1999. 
SOBESTIANSKY, J.; MORAES, N.; WENTZ, I.; MORENO, A.M. Manejo do leitão desde o nascimento até o abate. In: SOBESTIANSKY, J.R.; WENTZ, I.; SILVEIRA, P.R.S.; SESTE, L.A.C. Suinocultura intensiva: produção, manejo e saúde do rebanho. Brasília: EMBRAPA, SPI, Concórdia: EMBRAPA, CNPSA, 1998. cap.7, p.135-161.

SOUZA, P. Avaliação do índice de conforto térmico para matrizes suínas em gestação segundo as características do ambiente interno. Campinas, 2002. 102p. Tese (Doutorado) - Faculdade de Engenharia Agrícola, Universidade Estadual de Campinas.

SURFER (WIN 32) Version 6.01 - Aug 31 1995. Surface Mapping System. CopyrightC 1993-95, Golden Software, Inc.

SVENDSEN, J.; BILLE, N. Reducing baby pig mortality. In: LEMMAN, A.D.; GLOCK, R.D.; MENGELING, W.L.; PENNY, R.H.C.; SCHOOL, E.; STRAN, B. Diseases of swine. 5. ed. Ames: The Iowa State University Press, 1981. p.729-736.

TERUI, S.; TERADA, Y.; KARIYA, Y. Studies of meteorological factors on physiological functions in cattle. Journal Bulletin National Grassland Research, v.32, p.59-65, 1984.

TOLON, Y.B. Avaliação do ambiente gerado pelo resfriamento adiabático em maternidade de suínos e determinação de modelos de previsão de parâmetros de conforto. Campinas, 2002. 165p. Tese (Doutorado) - Faculdade de Engenharia Agrícola, Universidade Estadual de Campinas.

VAN WAGENBER, A.V.; BJERG, B.; BOT, G.P.A. Measurements and simulation of climatic conditions in the animal occupied zone in a door ventilated room for piglets. CIGR Journal of Scientific Research and Development. Manuscript BC 03020. April, 2004. 
VAN WAGENBER, A.V.; SMOLDERS, M.A.H.H. The effectiveness of ventilation in pig facilities: development and practical operation of a new measuring technique. INTERNATIONAL CONFERENCE IN SWINE HOUSING, 1., Iowa, 2000. Proceedings. Iowa: ASAE, 2000. p.10-17.

VAQUERO, E.G. Projeto e construção de alojamento para animais. 7.ed. Lisboa: Litexa, 1981.237p.

VEIT, H.P.; TROUTT, H.F. Monitoring air quality for livestock respiratory health. Veterinary Medicine and Small Animal Clinician, v.77, p.454-464, 1998.

VERLINDE, W,; GABRIELS, D.; CHRISTIAENS, J.P.A. Ventilation coefficient for wind-induced natural ventilation in cattle buildings: a scale model study in a windy tunnel. Transactions of the ASAE, v.41, n.3, p.783-788, 1998.

XIN, H.; ZHANG, Q. Preference for lamp or mat heat by piglets at cool and warm ambient temperatures with low to high drafts. Applied Engineering in Agriculture, v.15, n.5, p.547-551, 1999.

ZHANG, G.; MORSING, S.; STROM, J.S.; RAVN, P. Air motion temperature distribution within covered pig creep zones in rooms. INTERNATIONAL SYMPOSIUM, ASAE, 6., Louisville, 2001. Proceedings. Louisville: ASAE, 2001. p.262-269.

ZHANG, Q.; XIN, H. Modeling heat mat operation for piglet creep heating. Transactions of the ASAE, v.43, n.5, p. 1261-1267, 2000.

ZHANG, Q.; XIN, H. Responses of piglets to creep heat type and location in farrowing crate. Applied Engineering in Agriculture, v.17, n.4, p.515-519, 2001. 